\author{
Coordinador \\ Juan Antonio \\ Garza Sánchez
}

Prólogo: Héctor Fouce Rodríguez

\title{
Esfera Pública y Economía \\ Política de la Comunicación \\ El caso del Gasolinazo en Monterrey
}

Cuadernos Artesanos de Comunicación / 147
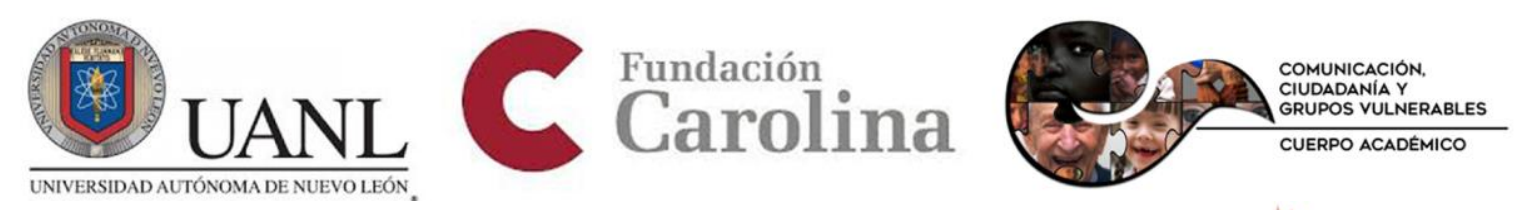

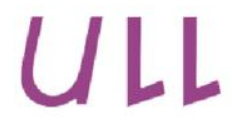

Universidad de La Laguna

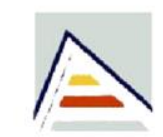

Universitat d'Alacant Universidad de Alicante

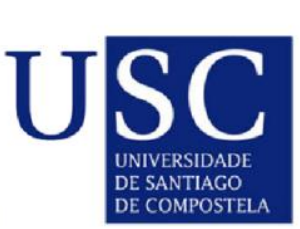

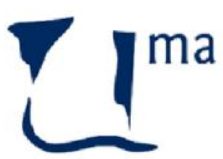

UNIVERSIDAD

DEMALAGA

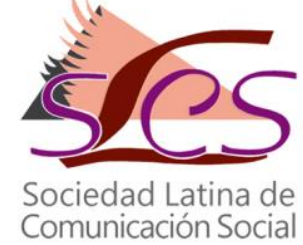




\section{Cuadernos Artesanos de Comunicación}

Coordinador editorial: José Manuel de Pablos - jpablos@ull.edu.es

Comité Científico

Presidencia: José Luis Piñuel Raigada (UCM)

Secretaría: Milena Trenta

- Ramón Zallo (Universidad del País Vasco, UPV-EHU)

- Núria Almirón (Universidad Pompeu Fabra, UPF)

- Francisco Campos Freire (Universidad de Santiago de Compostela)

- José Cisneros (Benemérita Universidad Autónoma de Puebla, BUAP)

- Bernardo Díaz Nosty (Universidad de Málaga, UMA)

- Carlos Elías (Universidad Carlos III de Madrid, UC3M)

- Paulina B. Emanuelli (Universidad Nacional de Córdoba, UNC)

- José Luis González Esteban (Universitas Miguel Hernández de Elche, UMH)

- Marisa Humanes (Universidad Rey Juan Carlos, URJC)

- Juan José Igartua (Universidad de Salamanca, USAL)

- Xosé López (Universidad de Santiago de Compostela)

- Maricela López-Ornelas (Universidad Autónoma de Baja California, AUBC)

- Javier Marzal (Universidad Jaume I, UJI)

- José Antonio Meyer (Benemérita Universidad Autónoma de Puebla, BUAP)

- Ramón Reig (Universidad de Sevilla, US)

- Miquel Rodrigo Alsina (Universidad Pompeu Fabra, UPF)

- Xosé Soengas (Universidad de Santiago de Compostela)

- José Luis Terrón (Universidad Autónoma de Barcelona, UAB)

- José Miguel Túñez (Universidad de Santiago, USC)

- Victoria Tur (Universidad de Alicante, UA)

- Miguel Vicente (Universidad de Valladolid, UVA)

* Queda expresamente autorizada la reproducción total o parcial de los textos publicados en este libro, en cualquier formato o soporte imaginables, salvo por explícita voluntad en contra del autor o autora o en caso de ediciones con ánimo de lucro. Las publicaciones donde se incluyan textos de esta publicación serán ediciones no comerciales y han de estar igualmente acogidas a Creative Commons. Harán constar esta licencia y el carácter no venal de la publicación.

\section{(c) $(1) \odot$}

EY NO No Este libro y cada uno de los capítulos que contiene, así como las imágenes incluidas, si no se indica lo contrario, se encuentran bajo una Licencia Creative Commons Atribución-No Comercial-Sin Derivadas 3.0 Unported.

Puede ver una copia de esta licencia en

http://creativecommons.org/licenses/by-nc-nd/3.0/ Esto significa que Ud. es libre de reproducir y distribuir esta obra, siempre que cite la autoría, que no se use con fines comerciales o lucrativos y que no haga ninguna obra derivada. Si quiere hacer alguna de las cosas que aparecen como no permitidas, contacte con los coordinadores del libro o con el autor del capítulo correspondiente.

* La responsabilidad de cada texto es de su autor o autora. 
Juan Antonio Garza Sánchez (Coordinador)

Prólogo: Héctor Fouce Rodríguez

\section{Esfera Pública y Economía Política de la Comunicación El caso del Gasolinazo en Monterrey}

Autores/as

Juan Antonio Garza Sánchez

Daniela Mendoza Luna

Moncerrat Arango Morales

Laura Lizeth Campos Guido

Margarita E. González Treviño

Hiram Garrido Ledezma

Xitlalic Candia Cortés
Colaboradores/as

Ana Victoria Félix Lamas Brandon Eliud Ipiña Aldaba Carlos E. Ortega Gutiérrez Juan Pablo Galván García Kelly Yohana Molina Bustos Paloma Elizabeth Flores Tudon

Cuadernos Artesanos de Comunicación / 147
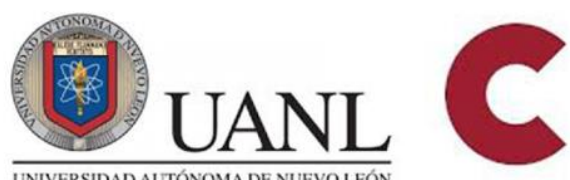

Fundación Carolina

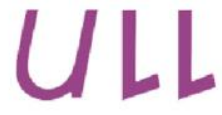

Universidad de La Laguna

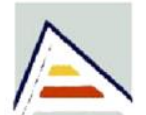

Universitat d'Alacant Universidad de Alicante

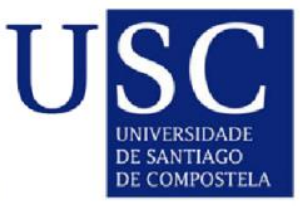

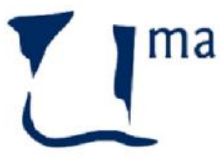

UNIVERSIDAD DE MALAGA
COMUNICACIÓN, CIUDADANIA Y
GRUPOS VULNERABLES CUERPO ACADEMICO

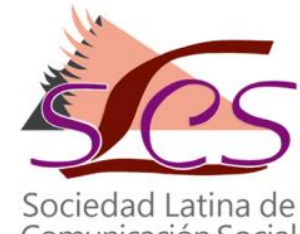




\section{CAC147 - Esfera Pública y Economía Política de la}

Comunicación. El caso del Gazolinazo en Monterrey

Autor o coordinador: Juan Antonio Garza Sánchez

| Precio social: 6,30€ | Precio en librería. 8,20€ |

Editores: Javier Herrero y Milena Trenta

Diseño: F. Drago

Ilustración de portada: Fragmento del cuadro "xxx"

Imprime y distribuye: F. Drago. Andocopias S. L.

c/ La Hornera, 41. La Laguna. Tenerife.

Teléfono: 922250554 | fotocopiasdrago@,telefonica.net

Edita: Sociedad Latina de Comunicación Social - edición no venal - La Laguna (Tenerife), 2017 - Creative Commons

http://www.revistalatinacs.org/14SLCS/portada2014.html

Descargar en pdf:

http://www.cuadernosartesanos.org/\#147

Protocolo de envío de manuscritos con destino a CAC: (la colección que corresponda)

http://www.cuadernosartesanos.org/protocolo.html

ISBN - 13: 978-84-17314-03-3

DL: TF-925-2018

DOI: $10.4185 /$ cac147 


\section{Agradecimientos:}

El presente documento es un esfuerzo hecho por el Cuerpo Académico "Comunicación, Ciudadanía y Grupos Vulnerables" y un grupo de colaboradoras y colaboradores que durante el verano del 2017, a través del Programa de Verano de la Investigación Científica que impulsa la UANL, realizaron para visibilizar un evento ocurrido en la esfera pública; así como los actores que incidieron en la conformación de lo que se denominó: el fenómeno del gasolinazo en Nuevo León. Cabe aclarar que este trabajo es un fragmento de lo que investigadores miembros de la red de Estudios Mediáticos de la Agenda Pública vienen haciendo desde el 2012. Una red de investigación conformada por Universidades europeas y latinoamericanas y de la cual nos enorgullecemos de pertenecer.

Queremos agradecer especialmente a funcionarios de nuestra Institución, que con su gestión y apoyo han hecho posible que este proyecto se vea cristalizado: Dra. Patricia del Carmen Zambrano Robledo, Directora de Investigación, Dr. Juan Manuel Alcocer González, Secretario de Investigación Científica y Desarrollo Tecnológico, y por supuesto a nuestro Rector Maestro Rogelio Garza Rivera, y por último a PAICYT 2018 no solo por el apoyo sino también por la motivación para continuar trabajando.

Finalmente, pero no menos importante, agradecemos a Samuel García Sepúlveda, Gilberto Lozano González, Melva Frutos Ayala, Mayte Villasana, Leticia Benavides, Osvaldo Robles López y Alberto Abrego Rodríguez, quienes accedieron a ser entrevistados por colaboradores y estudiantes de este libro, y que con sus respuestas enriquecieron y matizaron los resultados obtenidos en el análisis de contenido de la prensa escrita y las redes sociales. La Esfera Pública somos todos. 


\section{INDICE}

Prólogo

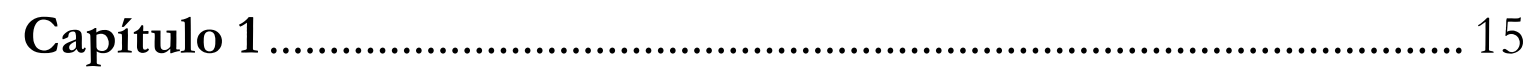

El "Gasolinazo", del asunto a la controversia que llevó a la protesta social: una visión holística......................................................................... 15

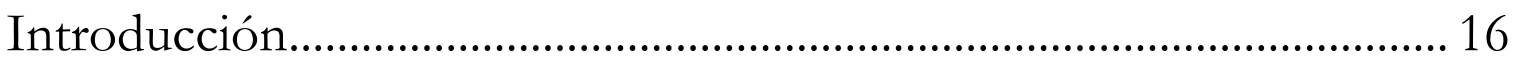

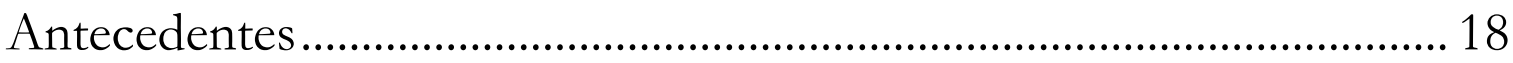

La esfera pública regiomontana .............................................................. 19

Inician los movimientos sociales en Nuevo León en la época contemporánea. .................................................................................. 20

De la inconformidad social a la demanda social ..................................... 22

Conclusiones .................................................................................... 24

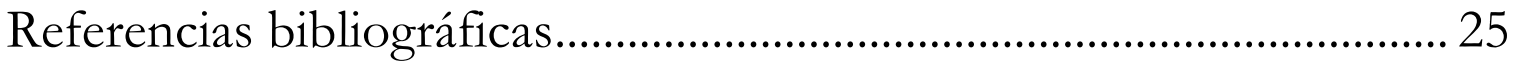

Capítulo 2 ……………………………………………………..... 27

El gasolinazo en los medios tradicionales............................................. 27

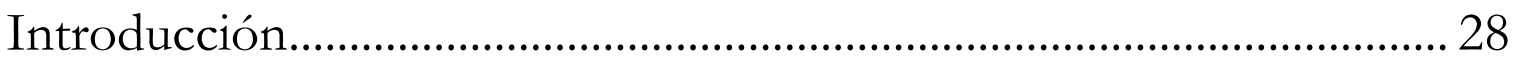

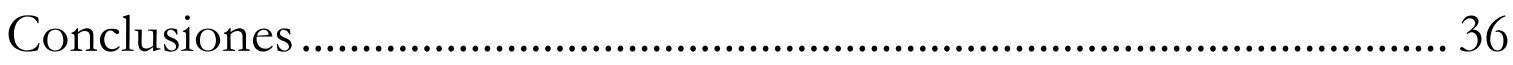

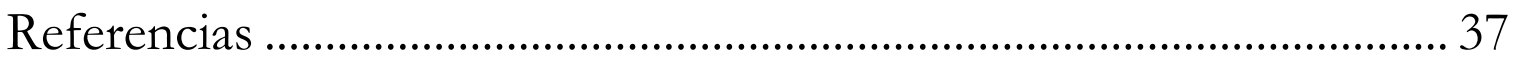

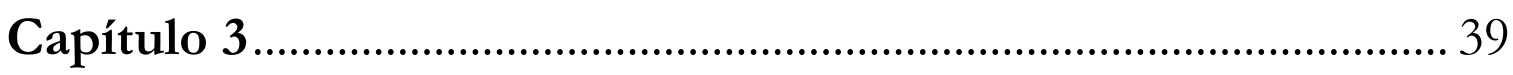

Las redes sociales en la esfera pública como escaparate de problemáticas sociales ................................................................................ 39

El impacto que tienen las redes sociales virtuales.................................... 42

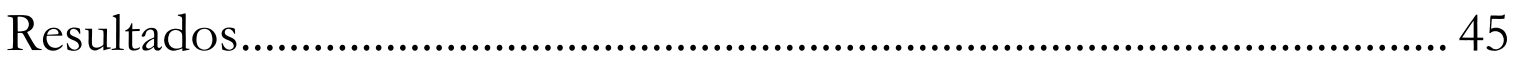

Conclusiones .................................................................................. 47

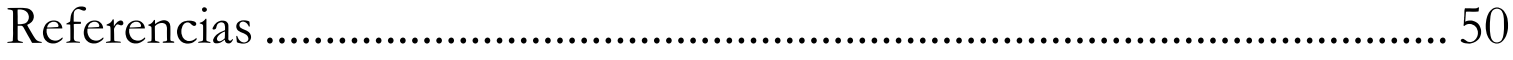


Capítulo 4.

Esfera pública y economía política de la comunicación. El caso del gasolinazo en Monterrey .......................................................................... 53

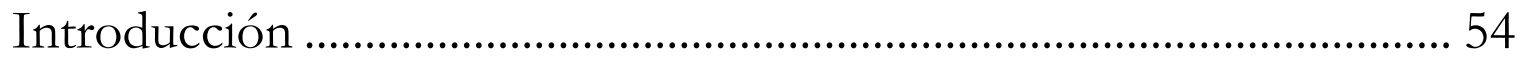

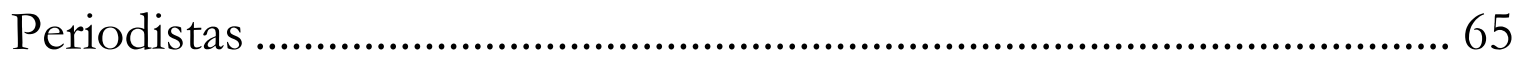

Medios de comunicación y sus representantes ........................................ 65

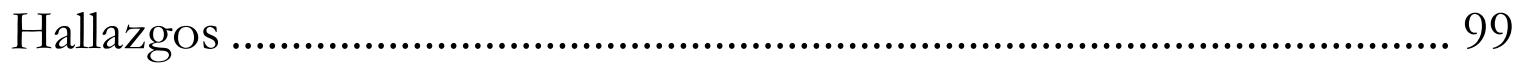

Sobre el papel de las redes sociales ......................................................... 99

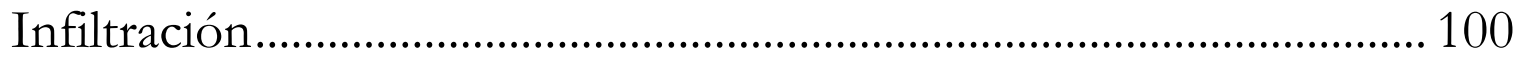

Sobre la difusión de información falsa ................................................. 102

Sobre la agresión a los medios de comunicación.................................. 103

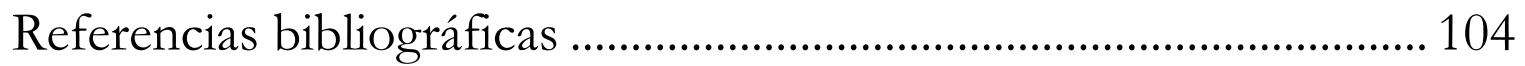

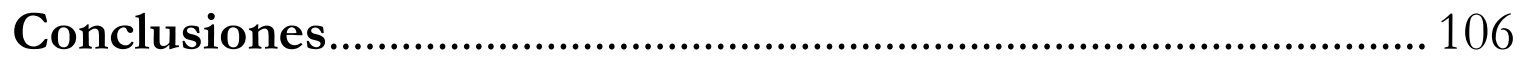

Ciudadanía, medios de comunicación y redes sociales; una triada que genera luchas visibles, reconocimiento y credibilidad.......................... 106

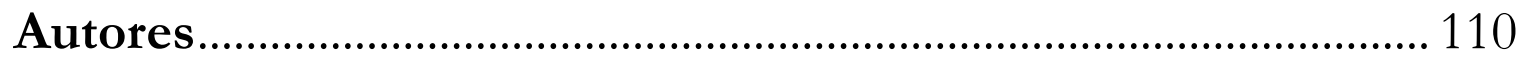

\section{El contenido de este libro ha sido sometido a un proceso de revisión de doble ciego por pares, semejante al sistema de revisión de un artículo científico para un journal.}




\title{
Esfera Pública y Economía Política de la Comunicación El caso del Gasolinazo en Monterrey
}

\author{
Juan Antonio Garza Sánchez \\ Coordinador
}

\section{Resumen}

En la modernidad, han sido los medios de comunicación de masas los espacios en los que los ciudadanos discutían sobre los problemas comunes y ejercían su influencia en la esfera política. El presente documento es un esfuerzo hecho por el Cuerpo Académico "Comunicación, Ciudadanía y Grupos Vulnerables" y un grupo de colaboradoras y colaboradores que durante el verano del 2017, a través del Programa de Verano de la Investigación Científica que impulsa la UANL, realizaron para analizar y abordar desde distintas aristas un evento ocurrido en la esfera pública; así como los actores que incidieron en la conformación de lo que se denominó: el fenómeno del gasolinazo en Nuevo León. Cabe aclarar que este trabajo es un fragmento de lo que investigadores miembros de la red de Estudios Mediáticos de la Agenda Pública vienen haciendo desde el 2012. Una red de investigación conformada por Universidades europeas y latinoamericanas y de la cual nos enorgullecemos de pertenecer.

\section{Palabras Clave}

Gasolinazo, Esfera Pública, Economía Política, Ciudadanía, Empoderamiento Ciudadano.

\section{Forma de citar este libro:}

José Antonio Garza Sánchez (2018): Esfera Pública y Economía Politica de la Comunicación. El caso del Gasolinazo en Monterrey. Cuadernos Artesanos de Comunicación, 147. Latina (La Laguna, Tenerife) 


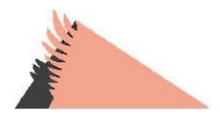 \\ Prólogo}

— RENTE a quienes defienden una visión burocrática de la 1 democracia, basada en el funcionamiento de las instituciones y en la celebración pautada de elecciones, son cada vez más las voces que reclaman poner en el centro de la democracia el papel del disenso. Una democracia debería ser un espacio deliberativo en el que se pudiesen escuchar múltiples opiniones a través de diferentes canales. Y si bien es necesario generar consensos para tomar decisiones que atañen al conjunto de los ciudadanos, estos serán siempre contingentes, el inicio de una nueva discusión. El espacio común, decía Hannah Arendt, desaparece cuando solo hay una perspectiva representada en el discurso social.

En la modernidad, han sido los medios de comunicación de masas los espacios en los que los ciudadanos discutían sobre los problemas comunes y ejercían su influencia en la esfera política, que no podía obviar el papel de la prensa como cuarto poder por mucho que la soberanía residiese en el Parlamento. Pero también la calle ha sido históricamente el lugar de expresión del descontento de las clases populares, un espacio de expresión política que los gobiernos no podían desatender a riesgo de su propia supervivencia.

En nuestros días, un tercer espacio de participación política surge de la mano de internet: las redes sociales facilitan que ciudadanos anónimos manifiesten sus puntos de vistas y llamen a la acción, permiten la discusión y la difusión de información. Pero cada vez somos más conscientes de que la capacidad de generar una conversación de las redes sociales corre en paralelo con su potencial disruptivo, divulgando noticias falsas, promoviendo linchamientos públicos, radicalizando las posturas de la discusión. 
Este trabajo colectivo aborda cada una de estas dinámicas en el caso mexicano, a raíz de las protestas sociales en Monterrey por la subida de los precios de la gasolina en enero de 2017. Lo hace desde una perspectiva amplia y desde un conjunto variado de metodologías con el objetivo de dar una visión completa y a la vez compleja del conflicto. Se analizan los discursos producidos por los medios, la influencia en estos de las estructuras de propiedad, la interacción de los medios con las manifestaciones y el papel mediatizador de las redes sociales, que se constituyen al tiempo en fuentes de información (de muy diferentes niveles de fiabilidad) y en espacios políticos en los que nuevos actores ganan legitimidad que después serán capaces de capitalizar con su presencia en las instituciones.

La investigación es uno de los resultados de un trabajo de colaboración entre una red de universidades europeas y latinoamericanas, que desde 2012 venimos trabajando en paralelo sobre las transformaciones de la esfera pública en la era de los medios digitales. Por el lado europeo, la universidad Complutense y la de Castilla-La Mancha en España, la universidad de Urbino Carlo Bo en Italia y la universidad de Paris III en Francia. Desde el otro lado del Atlántico, la universidad de Puerto Rico, la universidad de la Frontera en Chile, y desde México las universidades de Nuevo León y Coahuila. Las visitas de investigadores entre unos y otras se han repetido en los últimos años al amparo de diferentes proyectos.

La investigación arrancó poniendo el foco en los issues, los asuntos que los medios seleccionan para focalizar la información. Nos centramos en un primer momento en la construcción de los relatos por parte de los medios, preguntándonos de qué manera se usan los géneros periodísticos, como se construye cronológicamente el relato, de qué manera el sesgo de cada uno de los medios afecta a los protagonistas y las perspectivas de las historias. A partir de un eje que arrancaba en el asunto y era transformado en el relato, llegamos a las controversias que estos relatos generan.

Si bien es cierto que buena parte de estas formas de hacer se enmarcan en unas habilidades y rutinas profesionales que están más o manos homologadas a nivel internacional, no podíamos obviar que cada 
contexto genera unas modulaciones bien diferentes en el eje asuntorelato-controversia. La realidad social mexicana no es la de España, ni su ecosistema de medios funciona de igual modo. En ambas orillas asumimos que es necesario considerar como factores moduladores de la controversia y del relato periodístico tanto las estructuras de propiedad de los medios como las maneras en las que el sistema político interactúa con el sistema de medios. Y en este punto la investigación se complica cada día al considerar el creciente papel de las redes sociales, que ya son un ágora que ni los medios ni los políticos pueden ignorar y que los ciudadanos han ocupado. Las redes son así un espacio ambivalente en su relación con los medios: son altavoces de las noticias de los periódicos y las televisiones, pero son al tiempo fuentes (las más de las veces problemáticas) para los periodistas y también competencia directa en la mermada atención del público.

En las protestas del gasolinazo en Monterrey todas estas dinámicas mediáticas interactúan con un conflicto que, a la antigua usanza, se desarrolla en las calles de la ciudad. Lo que nos recuerda, como sucedió en España con la ocupación de las plazas el 15M de 2011, que la mediatización de nuestras sociedades y de nuestros procesos comunicativos no está reñido con una dimensión física, táctil y espacial de lo social y lo político. Nuestros trabajos en común pretenden pensar el papel que la mediatización juega en cada momento de nuestra vida en común: lejos de existir una esfera pública de carne y hueso separada de la esfera pública mediática, estas interaccionan. La llamada a las calles del 15M llegó tanto desde las redes sociales como desde la contemplación de la represión policial a través de los medios, del mismo modo que las redes avivaron las protestas del gasolinazo.

Nuestro trabajo común de investigación asume además que no todos los asuntos y temáticas tienen la misma presencia en la esfera pública, y que ésta ya no es única, sino fragmentada y especializada. Existen controversias que se desarrollan en ámbitos científicos y técnico y que raramente salen de estos. En nuestro caso, nuestros colegas de Urbino han estudiado los problemas generados por la obsolescencia programada de las tecnologías, y desde París han abordado la manera en que la discusión científica sobre la resistencia que desarrollamos a la acción de los antibióticos llega a los medios. Otras controversias 
arraigan en la periferia de la esfera pública y luchan por llegar a la esfera central: en el caso español, la crisis de la prensa y la discriminación de las mujeres en la industria cultural tienden a estar fuera del foco de los medios, a menos que estallen escándalos como los abusos sexuales de Harvey Weinstein en Hollywood y caras conocidas personifiquen la problemática, como ha pasado con el movimiento \#Metoo.

Otros asuntos llevan tiempo instalados en el corazón de la discusión pública: es el caso de las políticas en torno a la prostitución en España o el matrimonio homosexual en México. Asuntos que conectan la esfera mediática con las instituciones políticas y que son alimentados por voces diferentes que postulan puntos de vista en conflicto. Son controversias de largo aliento que a menudo permanecen aletargadas en el discurso de los medios hasta que un estudio, una votación de una ley, unas declaraciones de un personaje famoso o un suceso las colocan de nuevo en la agenda.

En el caso del gasolinazo, vemos la aparición de un problema público, de una demanda social que identifica una solución y pide que se tomen soluciones, en este caso para enmendar las decisiones gubernamentales. Es por ello que nos interesa ver quiénes son los actores de la protesta, cuál es el rol de la sociedad civil, cómo llega a interactuar con medios (considerando en especial el uso de las redes sociales como forma de difundir las propias posiciones) y cómo se apela a las instituciones políticas.

En nuestra investigación, de la que este libro muestra de forma compleja un episodio, laten implícitamente dos principios, que nacen de nuestra formación y sensibilidad como especialistas en comunicación y medios. La primera, ya explicada, es que el estado natural de la democracia es el disenso, administrado de forma constructiva como base de la acción social. La segunda, que una democracia requiere de ciudadanos informados, y que para ello los medios de comunicación tradicionales tienen un papel fundamental. En un ecosistema informativo en el que las fuentes crecen de forma inversamente proporcional a la capacidad de atenderlas, son imprescindibles unos medios profesionales capaces de investigar los asuntos públicos, comprometidos con la imparcialidad, la objetividad 
y la pluralidad de voces, obligados a contrastar la información por medio de una serie de procedimientos auditables. Solo así se puede generar información de calidad de manera que la discusión y el conflicto lleguen de la mano de un conocimiento fiable de la realidad social.

Estas premisas pueden ser usadas como guías para manejarse en la lectura de este trabajo, que ofrece diferentes perspectivas sobre el conflicto del gasolinazo. Permitirán así considerar este conflicto no sólo desde su naturaleza local, sino desde una perspectiva global, como una manera de indagar en la complejidad de la interacción entre ciudadanos, medios de comunicación, redes sociales y gobiernos.

Héctor Fouce Rodríguez Universidad Complutense de Madrid 



\title{
El "gasolinazo", del asunto a la controversia que llevó a la protesta social: una visión holística
}

\author{
Daniela Mendoza Luna \\ Laura Lizeth Campos Guido
}

Resumen: El presente capítulo aborda el proceso que pasó el asunto del gasolinazo, término que se le denominó al aumento de la gasolina en México, para convertirse en una en una protesta social en la ciudad de Monterrey, Nuevo León, México. A través de la aplicación de la técnica documental, los autores intentan realizar un recuento que enmarca el contexto del desarrollo de dicho fenómeno demostrando que en Nuevo León sucedieron una serie de hechos previos que permitieron la manifestación pública.

Palabras Clave: Manifestaciones sociales, gasolinazo, economía política de la comunicación.

Abstract: This chapter engages the process that passed the matter of the gasolinazo, a term that was called the increase of gasoline in Mexico, to become a social protest in the city of Monterrey, Nuevo León, Mexico. Through the application of the documentary technique, the authors try to make a recount that frames the context of the development of this phenomenon demonstrating that in Nuevo Leon a series of previous events that allowed the public manifestation happened.

Keywords: Social manifestations, gasolinazo, political economy of communication. 


\section{Introducción}

T OS ESTUDIOS de comunicación en México se encuentran ante $\perp$ el gran reto de responder, a la necesidad de explicar fenómenos sociales emergentes que surgen como respuesta ante el malestar social.

En un entorno de violencia, crisis de derechos humanos y desaceleración económica, la sociedad mexicana encuentra en las redes sociales una nueva arena política, donde plantear sus inquietudes, quejas y cuestionamientos al orden social.

"Dada la velocidad con que evolucionan los sistemas de comunicación, impulsados por la tecnología que han desencadenado en la llamada Sociedad de la Información, se abre más que nunca la posibilidad de un análisis que reflexione sobre el nuevo paradigma de la sociedad. Una sociedad informatizada que provoca un cambio en las estructuras políticas y económicas. Una sociedad en red, que de la mano del Internet pretende "beneficiar" a todos los humanos en este planeta. Actores, por cierto, en evidente desigualdad en acceso y apropiación" (Campos 2013, p.38).

Bajo el concepto de Habermas (1962), se entiende la esfera pública como el espacio de comunicación entre representantes políticos y ciudadanía que implica instituciones políticas, medios de comunicación y sociedad civil.

Bajo esta mirada, entendemos el término como un espacio de convergencia entre lo público y lo privado, en el que las demandas de la sociedad civil y las decisiones estatales interactúan, y en ocasiones se enfrentan. La sociedad presenta sus demandas, en tanto que el Estado justifica, explica y legitima sus actos y acciones.

El público es una forma de vida colectiva que se origina a partir de un problema, siendo al mismo tiempo parte del mismo. (Cefai, 2012). En este escenario los actores pueden ser entes en lo individual, $\mathrm{u}$ organizaciones que responden y se comprometen a un esfuerzo colectivo, ante una situación que perciben como problemática. 
Este mismo autor señala que "es el trastorno del "curso de las cosas", que hace percibir y definir una situación como problemática. El desorden sufrido puede parecer inicialmente borroso, ligeramente un desorden afectivo o una irritación moral, un rumor de reprobación o un sentimiento de algo inaceptable. Se va a tornar en el tema de un trabajo colectivo de identificación y de reconocimiento, de categorización y de estabilización que lo constituirá un problema público" (Cefai 2012, p.17).

Entonces deviene la protesta social como una expresión que demanda; como un contundente "no" a la situación actual, es la palabra que expresa varias voces, es la expresión del conflicto. La protesta es un grito de gente movilizada. En la protesta, la gente demanda algo. Todo conflicto no necesariamente es una protesta, pero toda protesta supone un conflicto donde la gente actúa.

En la configuración de la protesta intervienen los actores sociales que toman parte de la esfera pública, pero también las nuevas formas de comunicación que modifican y recodifican la política, los conflictos sociales $y$, en definitiva, el espacio público, que tienen un alcance informativo a escala universal inédito en la historia humana.

"Castells (2009) ha desarrollado la tesis de que la comunicación, y en especial la socializada, apoya la producción social de significados y es el campo de conflicto donde se expresan las personas y sus sociedades. Según el autor, las mutaciones tecnológicas en crecimiento, expanden el alcance de los medios a todas las esferas de la vida social en una red que es al mismo tiempo local, global, genérica y personal" (Castells en Calderón 2011, p. 53-54).

En el presente texto se reflexiona sobre la protesta social, como un medio para manifestar desacuerdos que afectan distintos ámbitos, es decir, acerca del tránsito de los asuntos de interés ciudadano a la esfera pública; primero mediante el uso de redes sociales, pasando por los medios masivos de comunicación, para finalmente convertirse en una protesta social, se habla específicamente de los hechos ocurridos el 5 
de enero del 2017, conocidos como la noche del "Gasolinazo" en Nuevo León.

Esta protesta, representa el hito de las movilizaciones sociales en la historia reciente de la entidad; una convocatoria masiva realizada a través de redes sociales, así como por diversos grupos de la sociedad civil, que de modo espontáneo sugirió salir a las calles a manifestar su desacuerdo con el incremento desmedido al precio de la gasolina.

La concentración de casi 15 mil personas, según cifras de Protección Civil del Estado de Nuevo León, fue producto de factores políticos, sociales y de seguridad; La suma de los agravios finalmente llegó al bolsillo de los ciudadanos, se convirtió en un problema colectivo; la corrupción galopante, la descomposición del Estado Mexicano y la crisis de derechos humanos habían sido observadas desde los medios de comunicación y las redes sociales, sin que el colectivo sintiera la necesidad de tomar las calles.

Pero a partir del 1 de enero de 2017, los incrementos en la gasolina que repercutieron en el encarecimiento del transporte público y privado, dejó de ser sinónimo del aumento que el combustible registraba cada mes, para transformarse en un movimiento social, denominado "gasolinazo".

\section{Antecedentes}

Las fluctuaciones en el costo de la gasolina eran consecuencia de la Reforma Energética, aprobada en el Congreso de la Unión el 26 de octubre de 2016, y que contenía impuestos especiales sobre la producción de servicios de gasolina magna, Premium y diésel; la promesa era que habría variaciones por un tiempo, antes de que finalmente se estabilizara a la baja.

Sin embargo, las fluctuaciones no se detuvieron, muy por el contrario, en diciembre del 2016 se anunció el aumento en el precio de la gasolina de casi un 20 por ciento para el inicio del siguiente año, previo a la liberalización del costo, y entonces empezaron las protestas. 
Desde el día 1 de enero de 2017 se presentaron las primeras manifestaciones; la carretera México-Querétaro se bloqueó por espacio de varias horas; manifestantes se congregaron en la Ciudad de México para marchar desde el Ángel de la Independencia hasta el Zócalo de la ciudad; se bloquearon diversas gasolineras; y hubo diversas manifestaciones con pancartas en diversos puntos del país.

De acuerdo con la Comisión Nacional de Seguridad, solo ese día se registraron 15 manifestaciones contra el gasolinazo en puntos carreteros como: Hidalgo, Ciudad de México, Durango, Chihuahua, Sinaloa y Oaxaca; dos de ellos bloqueos al tránsito, ocho tomas de casetas y cinco manifestaciones (Animal Político).

En Monterrey, Nuevo León, el 5 de enero, 15 mil personas (algunos señalan que la plancha de la Explanada de los Héroes alcanzaría hasta 50 mil personas) realizaron una protesta en la Macroplaza del centro de la capital nuevoleonesa, para exponer su inconformidad por las medidas tomadas por el gobierno federal.

\section{La esfera pública regiomontana}

Durante décadas, se ha exaltado el orgullo regiomontano en base a la cultura del trabajo y el esfuerzo; la dedicación como único camino para conseguir el éxito, y el éxito como la suma de bienes personales y materiales conseguidos solo gracias a largas jornadas laborales.

Esta construcción cultural exitosa, fue implantada tras algunos años turbulentos de protestas estudiantiles por la emancipación de la Universidad Autónoma de Nuevo León en 1972, y terminó con el cierre de la Fundidora de Fierro y Acero en 1986; el primer hecho culminó con la renuncia del gobernador Eduardo Elizondo, pero también con violentas represiones, el segundo con la culpabilización a los obreros por el quiebre de la empresa pública.

Esta etapa generó, a decir de González (2015) la introducción de una especie de "chip" perdedor o conformista para evitar que dos sectores combativos por naturaleza como los obreros y los universitarios, quedaran completamente desmovilizados. 
"El chip también fue reforzado con estrategias "amables". A principios de los noventa, desmovilizada ya gran parte de la población, Monterrey estaba listo para terminar de programar este chip. Fue el Gobierno de Carlos Salinas de Gortari, empresarios y la Iglesia, quienes terminaron de modelar la identidad regia. Con cinismo conservaron las palabras trabajador, honrado y ahorrador, para sostener una parte de la autoestima perdida; la que podía consumir productos y servicios: haciendo a un lado palabras humanistas como solidario, gentil o humildad" (González 2015, P. 177).

Al tener el estado una liquidez monetaria importante, gracias a la disposición geográfica que le permite hacer negocios directamente con los Estados Unidos, el primer socio comercial del país; contaba además con una excelente infraestructura y mano de obra preparada, el Estado se encontraba orgulloso de su estatus empresarial, por lo que el nivel de vida creció y se generó un imaginario comparativo, sobre que la calidad de vida no se daba como en otras partes de México, sino siendo el vecino del país de norte.

Sólo un movimiento importante "rompió" la calma de las movilizaciones y huelgas en el Estado; las protestas magisteriales que se registraron entre 1992 y 1994 por las modificaciones al sistema de retiro de los docentes; igualmente los manifestantes fueron estigmatizados en los medios de comunicación, y sus líderes cooptados, al final se llegó a un "acuerdo" con el Instituto de Seguridad y Servicios Sociales de los Trabajadores al Servicio del Estado de Nuevo León.

\section{Inician los movimientos sociales en Nuevo León en la época contemporánea}

A los años de "calma" siguió una época de peligro, el azote del crimen organizado producto de la "Guerra contra el Narcotráfico" iniciada en 2009 por el ex presidente Felipe Calderón Hinojosa, retumbó en la capital industrial del país, al grado que Lorenzo Zambrano, entonces director de Cemex, una de las empresas más importantes de Latinoamérica señaló: "Si cae Monterrey, cae México". 
Si bien la clase empresarial inicio un trabajo de colaboración con el Gobierno del Estado en la creación de una corporación policial más especializada, Fuerza Civil, sin embargo, la preparación de los elementos que la integrarían, se llevó un tiempo prolongado. Mientras tanto los cobros de piso, las desapariciones forzada, los enfrentamientos en la vía pública, ejecuciones, y posteriormente acontecimientos como el atentado contra el Casino Royale, y el asesinato de dos estudiantes del Instituto Tecnológico y de Estadios Superiores de Monterrey (ITESM), detonaron en la sociedad regiomontana un deseo de exigencia social que no se había presentado con anterioridad.

La muerte de Jorge y Javier, en marzo de 2009, significó la primera protesta de la llamada "primavera regiomontana"; sólo juntó a 300 personas que se reunieron ante un protegido Palacio de Gobierno, que había sido circundado con vallas para tratar de desanimar a los asistentes, pero que realmente solo consiguió gestar la semilla de un grupo de estudiantes que después apoyarían distintos movimientos sociales.

Los expedientes de víctimas generados por desaparición forzada, se acumulaban sobre los escritorios de los ministerios públicos, sin que hubiera respuesta para sus padres; el arribo de la "Caravana por la Paz con Justicia y Dignidad" que dirigía Javier Sicilia, el 7 de junio de 2011, no solo llenó la plaza de Colegio Civil, sino que también trajo un impulso importante a este movimiento. Entre las actividades que este grupo lleva a cabo, no se encuentra únicamente el hecho de manifestarse semana a semana, sino que llevaron a cabo la toma simbólica de una plaza pública, le cambiaron el nombre por el de "La Víspera de la Espera", y la reclamaron como propia.

Posteriormente, el 28 de agosto de 2011 y solo tres días después de que 52 personas, la mayoría mujeres murieran en el atentado al casino Royale, casi 6 mil personas de diversos colectivos se plantaron en la Explanada de los Héroes para exigir un alto a la impunidad con la que los carteles de la droga transitaban por la ciudad. 
Los grupos de activismo comenzaron a reunirse de modo mensual, y las escalinatas del Museo de Historia Mexicana se convirtieron en una especie de "ágora" en la que el evento titulado "+ Allá de la Marcha", siguió empoderando a distintos grupos sociales e inspirando la creación de nuevos colectivos como la Asamblea Estudiantil UANL.

Aunado a estos acontecimientos, sobrevino la defensa del parque la Pastora que buscaba impedir la construcción del estadio BBVA Bancomer, en territorios de este espacio natural protegido, las acciones contra el llamado "Chapulinazo", que buscaba impedir que la alcaldesa de Guadalupe, Ivonne Álvarez, y el presidente municipal de Monterrey, Fernando Larrazábal, dejaran sus puestos para contender en las elecciones de 2012 a escaños en el Congreso de la Unión.

En 2016, pocos, pero bien organizados maestros de la Coordinadora Nacional de Trabajadores de la Educación, comenzaron a tomar las calles de la ciudad en protesta por la Reforma Educativa; llegaban a concentrar hasta 3 mil personas, en ocasiones cerrando la vialidad de avenidas importantes como Ignacio Morones Prieto y Benito Juárez,

Las causas y los movimientos comenzaron a amalgamarse, de tal modo que, cuando en 2017 la indignación por el alza en el precio de la gasolina, y las protestas "espejo" que había en otras entidades del país, provocaron un efecto en cascada de convocatorias a una marcha.

\section{De la inconformidad social a la demanda social}

El incremento de la gasolina trajo consigo la posibilidad de que aumentara el precio del transporte público, un servicio ya considerado como el más caro en el país y que es utilizado diariamente por 3 millones de personas en la ciudad. Esta información nos lleva a reflexionar sobre el aspecto humano de este fenómeno denominado gasolinazo. Independientemente del aspecto ideológico, se deben tomar en cuenta las cuestiones materiales, lo que pego en el bolsillo del ciudadano no puede quedar a un lado.

En concordancia con lo antes expuesto, cabe destacar que los primeros grupos en protestar por el alza en la gasolina fueron los transportistas 
de la región citrícola de Nuevo León, pequeños empresarios que cuentan con 3 o 5 unidades y que veían mermadas sus ganancias por el encarecimiento del transporte.

"La gente se manifiesta por objetivos concretos y pragmáticos, más que por razones trascendentales, valores o creencias absolutas. Se maneja un doble código en la relación entre ideología y necesidad: prevalece una racionalidad práctica por la cual se hace un uso instrumental de las ideologías, que ya no son el motor principal de las movilizaciones" (Calderón 2011, p. 127).

El carácter del agravio no fue solo moral, sino que pegó directamente en las llamadas medidas de bienestar; los impactos negativos de la liberalización de la gasolina, fueron generales, y la promesa de la estabilidad en el precio no se ha concretado. El gasolinazo significó un golpe directo y certero a la única red de seguridad con la que se sostenía el ciudadano.

A decir de Marco Aranda, doctor en ciencia social con especialidad en sociología por El Colegio de México, miembro del Sistema Nacional de Investigadores (SNI) nivel 1 y profesor investigador del Instituto de Investigaciones Sociales de la Universidad Autónoma de Nuevo León (UANL), la frustración e indignación acumulada como consecuencia del agravio al bolsillo de la comunidad, fue politizada por las organizaciones sociales encargadas de organizar las demandas, provocaron que la sociedad saliera a las calles a manifestarse. (M, Aranda. Comunicación personal, 18 agosto 2018)

Este mismo autor señala que no únicamente un segmento determinado de la población fue agraviado, también lo fueron las victimas del crimen organizado, lo cual indica que existe un rango más amplio de clases, y por lo mismo se vuelve un tanto más complicada la articulación política, para articular intereses de clase.

Las movilizaciones ciudadanas se han dividido históricamente en clases, en base a las problemáticas que sufren ciertos sectores; sin embargo, cuando se trata de un producto de consumo imprescindible 
y masivo, no había modo de deslindarse, incluso en los grupos más conservadores de la sociedad.

"La capacidad organizativa y de movilización de la gran mayoría, se ha demostrado en coyunturas históricas capaces de producirlas, rebasando en muchas oportunidades a las propias vanguardias. Asimismo, en situaciones de reflujo, persisten formas de lucha adecuadas a esa situación” (Guerra 1979).

\section{Conclusiones}

Los efectos del "gasolinazo" en las redes sociales siguen siendo motivo de polémica. De acuerdo a un estudio de Espinosa y Asociados, consultoría digital, que realizó un análisis a un universo de cuentas en redes sociales, entre el 28 de diciembre del 2016 y el 14 de enero del 2017, el contenido numérico referido al "gasolinazo", paso de mil 300 usuarios y 558 bots al inicio del ciclo y cerrando con 60 mil 350 usuarios verificados, y el 7 de enero llegó a su máximo nivel con 347 mil usuarios reales y 8,401 bots.

Por lo anterior, no es de extrañarse que la convocatoria se realizara a través de estos medios, y utilizado la herramienta "Eventos" de Facebook; en Nuevo León se registraron más de 10 grupos de manera espontánea: El Colectivo Nosotros, Únete Pueblo, Ciudadano Empoderado, Alianza Cívica, Asamblea Estudiantil UANL, Congreso Nacional Ciudadano, CNTE Monterrey, la porra Libres y Locos, ente otros. Todos salieron desde distintos puntos de la ciudad y aunque nunca hubo una organización general, tuvieron la capacidad de llegar y convocar a la sociedad civil en general.

Los puntos de partida fueron el Estadio Universitario, el Estadio BBVA, el Mercado Juárez, El Tec de Monterrey y la plaza del Colegio Civil, aunque, la mayoría de los asistentes a decir de los mismos organizadores, llegaron por su propio pie directamente a la explanada de los Héroes, juntándose prácticamente 15 mil personas.

La protesta se salió de control desde el primer momento; los oradores no pudieron hacer uso de la palabra según lo planeado, y las acciones 
de violencia comenzaron a pocos minutos de haber iniciado la concentración masiva.

La protesta, a decir de organizadores y periodistas, fue infiltrada por un grupo de vándalos que atacaron con piedras y bombas molotov al Palacio de Gobierno del Estado de Nuevo León. Los manifestantes se opusieron a este grupo de choque, gritando frases como "¡Ése no es el pueblo!, generando una línea divisoria muy marcada entre el pueblo y los personajes que llegaron únicamente a agredir, además de otras estrategias de distinción entre los "verdaderos manifestantes" y los "infiltrados".

El saldo fue de 182 detenciones, y la destrucción de los históricos vitrales de Palacio de Gobierno de Nuevo León; no hubo heridos, pero meses después, en un motín en el Penal del Topo Chico, donde esperaban juicio estos jóvenes, uno de ellos fue asesinado.

\section{Referencias bibliográficas}

Calderón, F, (2012). La protesta social en América Latina. México: Siglo XXI Editores.

Campos, L. (2013). La ruptura del monopolio televisivo en México. El caso de TV Azteca. Universidad Complutense de Madrid. España.

Cefaï, D. (2012). ¿Qué es una arena pública? Algunas pautas para un acercamiento pragmático. D. Cefaï, \& I. Joseph (Coords.).

González. (2015). Primavera Regia Pospuesta. México: Multiforo Cultural El Puente.

Guerra, E. (1979). La organización y la movilización social en la política social. Revista Acción Crítica, 6, 13.

Habermas, J. (1962). Historia y Crítica de la Opinión Pública. Madrid: Gustavo Gili Editores 1982. 
Redacción, (2017). Así fue el noveno día de protestas contra el gasolinazo; exigen la renuncia de Peña Nieto. Julio, 20, 2017, de Animal Político Sitio Web:

https://www.animalpolitico.com/2017/01/gasolinazo-novenodia-protestas/

Villanueva, E. (2017). Gasolinazo, redes sociales y bots. julio 20,2018, de Aristegui Noticias Sitio web:

https://aristeguinoticias.com/1701/mexico/gasolinazo-redessociales-y-bots/ 


\title{
El gasolinazo en los medios tradicionales
}

\author{
Montserrat Arango Morales \\ Laura Lizeth Campos Guido \\ Xitlalic Candia Cortés
}

\begin{abstract}
Resumen: El movimiento social denominado "Gasolinazo" que se llevó a cabo en varios estados de México los primeros días de 2017, a causa del mayor incremento en 20 años al precio de la gasolina, expuso de manera contundente el descontento social de la ciudadanía y la crisis de legitimidad política que existía en el país.

Este fenómeno, en Nuevo León, y la serie de hechos ocurridos alrededor del tema del gasolinazo, tuvieron una amplia cobertura mediática entre el mes de diciembre de 2016 hasta febrero de 2017. Por ello, y para analizar el desarrollo de la controversia en la esfera pública se realizó un análisis de contenido de seis medios tradicionales.

En este capítulo se analizará la información obtenida de dicho análisis, compuesto por 210 piezas noticiosas de seis medios de comunicación distintos, donde se analizaron variables como la extensión de la nota, el género, los actores que se mencionan, el tipo de atribución y la posición ante el hecho narrado.
\end{abstract}

Palabras clave: Gasolinazo, descontento social, cobertura mediática, esfera pública.

Abstract: The social movement called "Gasolinazo" that was carried out in several Mexican states in the first days of 2017, due to the 20year increase in the price of gasoline, strongly exposed the social discontent of the citizens and the crisis of political legitimacy that existed in the country. This phenomenon, in Nuevo León, and the series of events that occurred around the topic of gasolinazo, had wide 
media coverage between the month of December 2016 and February 2017. Therefore, and to analyze the development of the controversy in the sphere public, a content analysis of six traditional media was carried out.

In this chapter we will break down the information obtained from this analysis, made up of 210 news pieces from six different media, where variables such as the extension of the grade, the gender, the actors mentioned, the type of attribution and the position before the narrated fact.

Keywords: Gasolinazo, social discontent, media coverage, public sphere.

\section{Introducción}

— L GASOLINAZO fue una movilización social que se llevó a cabo en el país los primeros días del 2017 a causa del mayor incremento en 20 años al precio de la gasolina, esto a causa de su liberalización a las dinámicas del mercado global.

Esta movilización, además de mostrar la inconformidad de la ciudadanía con el aumento al combustible y el impacto indirecto que éste representaría para su economía familiar, evidencio la crisis de legitimidad política y el hartazgo social de un pueblo indignado, tal como se ha dado en los últimos años en otros países.

El gasolinazo inicio con protestas pacíficas y se fue transformando en una serie de saqueos, disturbios y toma de autopistas y gasolineras, con miles de personas detenidas, cientos de comercios robados, hurto de combustible, cierre de carreteras y pérdida de vidas.

Particularmente, en el estado de Nuevo León este movimiento tuvo relevancia por la cantidad de personas que atendieron a la convocatoria para manifestarse en contra del aumento al precio de la gasolina y el estigma de que éste es un estado que tiende a no movilizarse. La protesta llevada a cabo en el estado el día 5 de enero tuvo una asistencia de alrededor de 15 mil personas, de acuerdo a cifras de Protección Civil del Estado de Nuevo León. 
En la red, según los datos de Google Trends, el tema despertó curiosidad el 25 de diciembre; 6 días después, el primer día de enero, la búsqueda se había acrecentado al 100 por ciento manteniéndose así hasta el 7 de enero. En Facebook, abundaron los grupos relacionadas con el tema, muchos de ellos con decenas de miles de participantes; en la misma red social, las invitaciones a manifestaciones o a dejar de comprar gasolina los primeros tres días del año comenzaron a aparecer hacia el 29 de diciembre.

En Twitter el tema inició el 27 de diciembre, fecha en que se anunciaron los aumentos previstos, con la circulación de un tweet del presidente Enrique Peña Nieto del año 2015 en el que prometía la desaparición de los aumentos en el precio de la gasolina.

Utilizando las redes sociales, miles de ciudadanos compartieron sus discursos y posturas en un mundo virtual que terminó materializándose en acciones contundentes, algunas violentas, frente a los principales espacios urbanos que representan el poder político institucionalizado del país y, entonces, la controversia en torno al gasolinazo tomó otras dimensiones.

Los medios off line comenzaron a difundir información de las manifestaciones ciudadanas el último día del mes de diciembre, al mismo tiempo que difundían en sus versiones tradicionales (impresas y televisivas) los llamados ciudadanos realizados en internet a boicotear las gasolineras. En enero ocurría algo similar, aunado a la cobertura organizacional in situ de las manifestaciones, declaraciones y saqueos; recogían material de YouTube, Facebook, Twitter y WhatsApp producido por diversos actores ciudadanos, organizaciones y políticos.

Como reflejo de lo ocurrido Castells (2008) señala que, aunque los movimientos políticos contemporáneos utilicen ampliamente los "medios de comunicación individual", cuando intentan influir en la opinión pública tratan de buscar visibilidad en los medios tradicionales. Se trata pues de una nueva forma de hacer política, en la que los actores se apoyan en la "capacidad de una tecnología de red para distribuir horizontalmente mensajes que resuenan en la conciencia pública de una forma digna de confianza" generando nuevas esferas públicas; 
pero continúan buscando la exposición de los asuntos en los medios de comunicación para "maximizar su influencia sobre la opinión pública".

Por este motivo, para analizar el fenómeno del Gasolinazo se realizó un análisis de contenido en seis medios offline, los cuales fueron seleccionados de la siguiente forma:

Dos televisoras locales: Una de carácter público con cobertura estatal, Canal 28; y otra de carácter privado con cobertura regional, Tv Azteca Monterrey. Dicho criterio de selección responde a la necesidad de confrontar los discursos periodísticos, sobre la controversia del "gasolinazo", que utilizan estaciones de televisión que por su naturaleza buscan fines distintos.

Dos periódicos locales: Los periódicos El Norte y el ABC, que constituyen medios impresos de gran relevancia social entre la comunidad neolonesa. El primero representa al Grupo Reforma, una de las principales cadenas de periódicos con presencia a nivel nacional y amplio prestigio entre los sectores más favorecidos de la población. El segundo corresponde al Grupo Épsilon, una empresa local productora de medios que ha logrado posicionar a su diario como el líder de los periódicos gratuitos en la región.

Dos portales digitales de información nacionales: Dado la creciente penetración del internet en el panorama mexicano se incluyen los portales nativos digitales, Aristegui Noticias y SDP noticias. El primero fue creado por la periodista Carmen Aristegui, una de las personas más influyentes del país, cuyo número de seguidores ha crecido exponencialmente desde la publicación del reportaje de la Casa Blanca de Peña Nieto y el despido, de ella y de su equipo, del noticiero radiofónico en MVS a raíz de la exhibición del mencionado reportaje. SDP, por su parte, surgió con fines propagandísticos para apoyar la candidatura presidencial de Andrés Manuel López Obrador, hasta que fue comprado por el periodista regiomontano Federico Arreola quien convirtió el sitio en un blog noticioso desde 2011. 
En cuanto al periodo de análisis, se recogieron textos noticiosos desde el 15 de diciembre de 2016 hasta el 15 de febrero del 2017. Dicha temporalidad corresponde al inicio de la controversia, o lo que Dewey (2004) califica como la situación problemática, con el desabasto de combustible en algunas gasolineras de Monterrey y el área metropolitana, así como el final de la misma al decretarse que no se haría efectivo el primer aumento programado del precio de la gasolina.

La información que se recogió incluye: los datos de identificación (fecha y publicación), el título de la pieza informativa, su extensión (en tiempo o palabras según sea el caso), el género periodístico al que corresponde, una breve descripción del hecho que narra, los actores del hecho narrado (clasificados en 12 categorías distintas), el tipo de atribución (directa, con reserva, de reserva obligatoria o de reserva total), la posición ante el hecho (positiva, negativa o neutral), si la narración incluye hechos pasados, si sugiere hechos futuros y la inclusión de actores ajenos a la controversia (especialistas).

Tabla 1. Distribución de noticias por medio.

\begin{tabular}{|l|l|l|}
\hline Medio & Número de noticias & Porcentaje \\
\hline ABC & 100 & $47,6 \%$ \\
\hline EL NORTE & 36 & $17,1 \%$ \\
\hline AZTECA & 21 & $10,0 \%$ \\
\hline CANAL28 & 21 & $10,0 \%$ \\
\hline ARISTEGUI & 26 & $12,4 \%$ \\
\hline SDP & 6 & $2,9 \%$ \\
\hline
\end{tabular}

Fuente: Elaboración propia

La distribución de noticias por cada medio analizado se presenta en la tabla 1, en ella podemos observar que el medio con la mayor cantidad de piezas noticiosas sobre el tema es el periódico ABC, con 100 notas. La diferencia significativa en el número de notas de este medio frente a los otros se deriva del carácter del periódico $\mathrm{ABC}$, que al ser de distribución gratuita y editado pensando en facilitarle la lectura al usuario presenta varias notas breves sobre un mismo tema cada una presentando un aspecto diferente. 
Tabla 2. Extensión de piezas

\begin{tabular}{|l|l|l|l|l|l|l|}
\hline Medio & ABC & NORTE & AZTECA & $\begin{array}{l}\text { CANAL } \\
28\end{array}$ & ARISTEGUI & SDP \\
\hline $\begin{array}{l}\text { Más } \\
\text { larga }\end{array}$ & $\begin{array}{l}447 \\
\text { palabras }\end{array}$ & $\begin{array}{l}884 \\
\text { palabras }\end{array}$ & 4 min 28 s & $\begin{array}{l}12 \text { min } \\
51 \mathrm{~s}\end{array}$ & 1004 palabras & $\begin{array}{l}367 \\
\text { palabras }\end{array}$ \\
\hline $\begin{array}{l}\text { Más } \\
\text { corta }\end{array}$ & $\begin{array}{l}33 \\
\text { palabras }\end{array}$ & $\begin{array}{l}83 \\
\text { palabras }\end{array}$ & 1 min & $\begin{array}{l}1 \text { min } 6 \\
\mathrm{~s}\end{array}$ & 54 palabras & $\begin{array}{l}94 \\
\text { palabras }\end{array}$ \\
\hline
\end{tabular}

Fuente: Elaboración propia

Tal como se observa en la tabla 2 , donde se señala la extensión máxima de una nota en este medio con 447 palabras y la extensión mínima con solo 33 palabras.

Por el contrario, el periódico EL NORTE presenta solamente 36 notas, esto se atribuye a la línea editorial del medio, que va dirigido a un público más analítico y reflexivo; exponiendo una menor cantidad de notas, pero cada una de ellas más extensa, como se observa en la extensión de sus piezas: 884 palabras la más larga y 83 la más corta. (Véase tabla 2.)

Por su parte, ambas televisoras, Canal 28 y Azteca, presentan 21 notas cada una, sin embargo, varía la extensión de las notas, por un lado, la nota más extensa en Canal 28 es de 12 minutos 51 segundos frente a la pieza más extensa de Azteca con una duración de 4 minutos 28 segundos. (Véase tabla 2.) Esto justifica debido al carácter público del primer medio, donde a lo largo de la nota de 12 minutos se habla sobre las medidas para recortar gastos que tomó el gobierno estatal y el carácter privado de Azteca, donde el tiempo al aire se distribuye de acuerdo a fines económicos.

Adicionalmente, la distribución de piezas en los portales web queda de la siguiente forma: 26 notas en Aristegui noticias y 6 notas en SDP noticias. Por lo que se refiere a la distribución de la información durante el periodo estudiado, el $84.3 \%$ de las noticias se presentaron durante el mes de enero del 2017, el 9.5\% en diciembre del 2016 y el restante $6.2 \%$ en febrero de 2017 , como se puede observar en la tabla número 3. 


\section{Tabla 3. Distribución temporal de noticias}

\begin{tabular}{|l|l|l|}
\hline Mes & Número de noticias & Porcentaje \\
\hline Diciembre & 20 & $9,5 \%$ \\
\hline Enero & 177 & $84,3 \%$ \\
\hline Febrero & 13 & $6,2 \%$ \\
\hline Total & 210 & $100 \%$ \\
\hline
\end{tabular}

Fuente: Elaboración propia

Respecto a los picos informativos (véase tabla 4), cabe señalar que, durante el mes de diciembre, al inicio de la controversia, el día con mayor actividad informativa se presentó el 30 de dicho mes. 7 noticias, 6 periodísticas y una de un portal digital, informaron sobre la primera protesta realizada en la región, así como las largas filas para la compra de combustible debido al desabasto que comenzaba a manifestarse en la ciudad capital.

Durante el mes de enero, el día que mayor actividad informativa se presentó corresponde al 09 de dicho mes, $11.9 \%$ de las noticias de enero (10\% del total del corpus). Sobre su contenido, la información versa en torno a las medidas a tomar en contra de las personas que causaron los disturbios y saqueos durante las manifestaciones de días anteriores, así como un creciente número de declaraciones de actores gubernamentales relativas a la reducción de gastos en diferentes áreas de la administración pública.

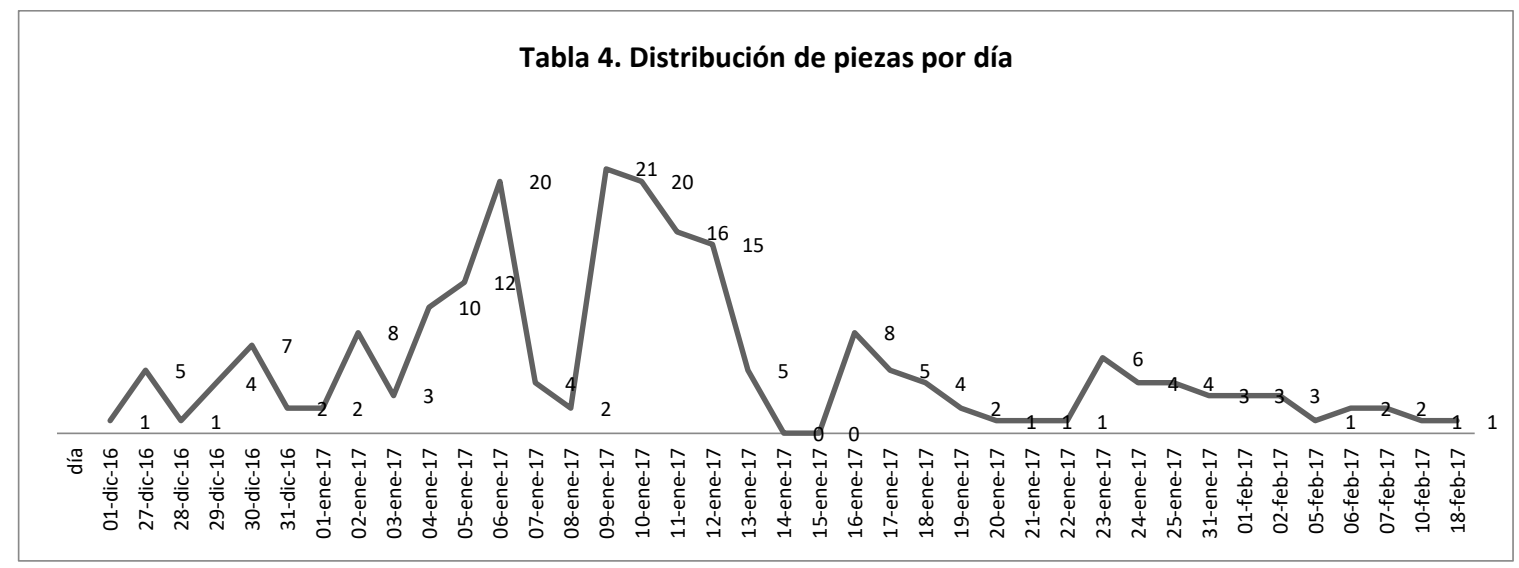

Fuente: Elaboración propia 
Dos días más de enero coinciden con picos informativos. El 06 se presentaron 20 piezas que narraron principalmente los hechos ocurridos durante la mayor manifestación pública en contra del aumento al precio de la gasolina. Por su parte, las 20 noticias que se publicaron el 10 de enero incluyen información sobre los detenidos en los disturbios de las manifestaciones, declaraciones hipotéticas sobre los actores y fines políticos de los participantes en los hechos, así como las declaraciones del Gobernador del Estado con la intensión de aliviar la carga económica de los ciudadanos.

Por lo que respecta al mes de febrero, la mayor cantidad de información se presenta el primer día del mes (3 noticias), narrando lo acontecido durante una nueva marcha ciudadana, y el día 2 de febrero (3 noticias), refiriendo un llamado al bloqueo de las gasolineras.

Por lo que se refiere a los géneros utilizados para narrar los hechos, podemos observar en la tabla 5 que el $83.8 \%$ de las piezas analizadas fueron noticias, lo que responde principalmente a la naturaleza del conflicto y a la necesidad de narrar los hechos de manera clara, objetiva y concreta. En igual cantidad de porcentaje, 3.8\%, se presentaron crónicas y entrevista. 5.2\% corresponden a géneros de opinión (incluidos artículos, columnas y editoriales); y $3.3 \%$ fueron reportajes.

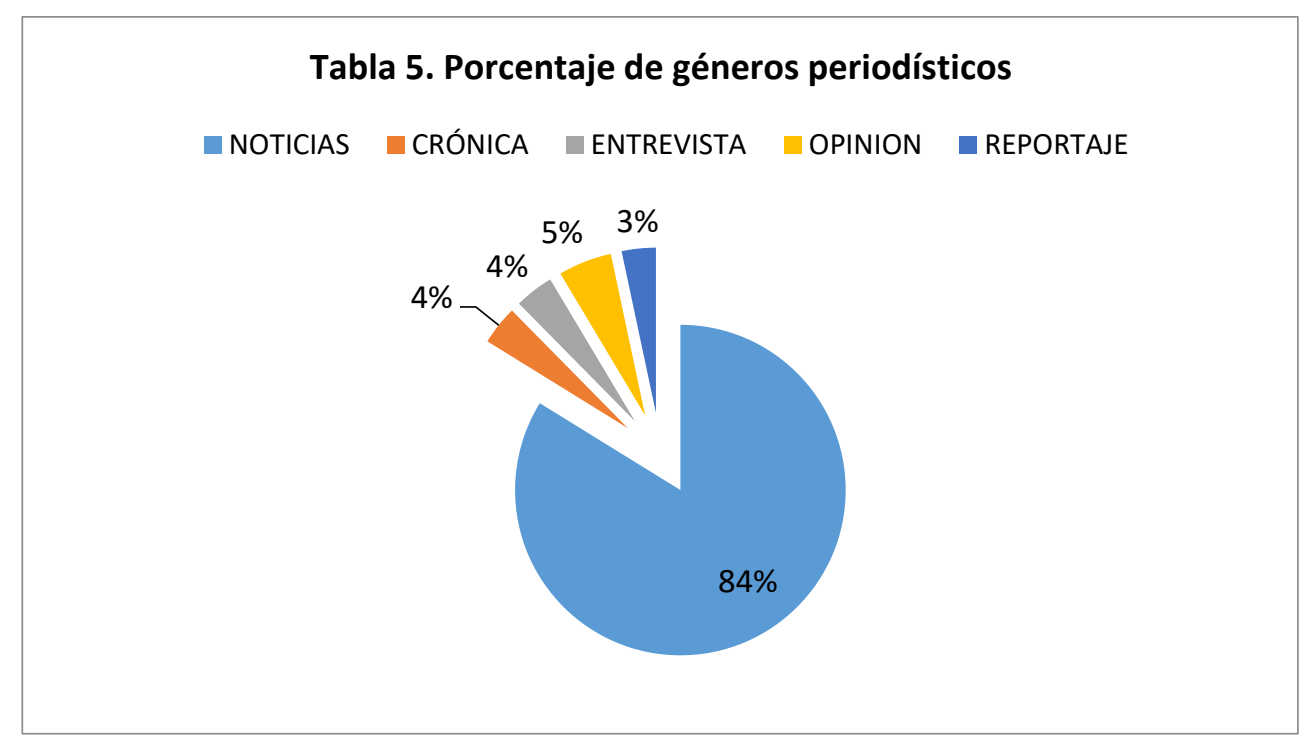

Fuente: Elaboración propia

Finalmente, hemos podido identificar a más de 250 actores distintos en el corpus de la controversia narrada. Agrupados en 12 clases 
distintas, la mayor proporción corresponde a la categoría de organizaciones civiles (21\%), seguido de la categoría denominada ciudadanía (13.4\%); se trata de un dato por demás significativo entorno a la temática de la construcción de la esfera pública, sin embargo, se trata también de un resultado esperado en función de la naturaleza de los sucesos en torno a las manifestaciones ciudadanas. La categoría con menor presencia corresponde a la nombrada: "otros medios", cuyas piezas informativas (2) pertenecen a los portales de internet. En este sentido valdría la pena mencionar que se trata de dos medios localizados geográficamente en la capital del país, lo que podría explicar la utilización de información originada por informativos locales.

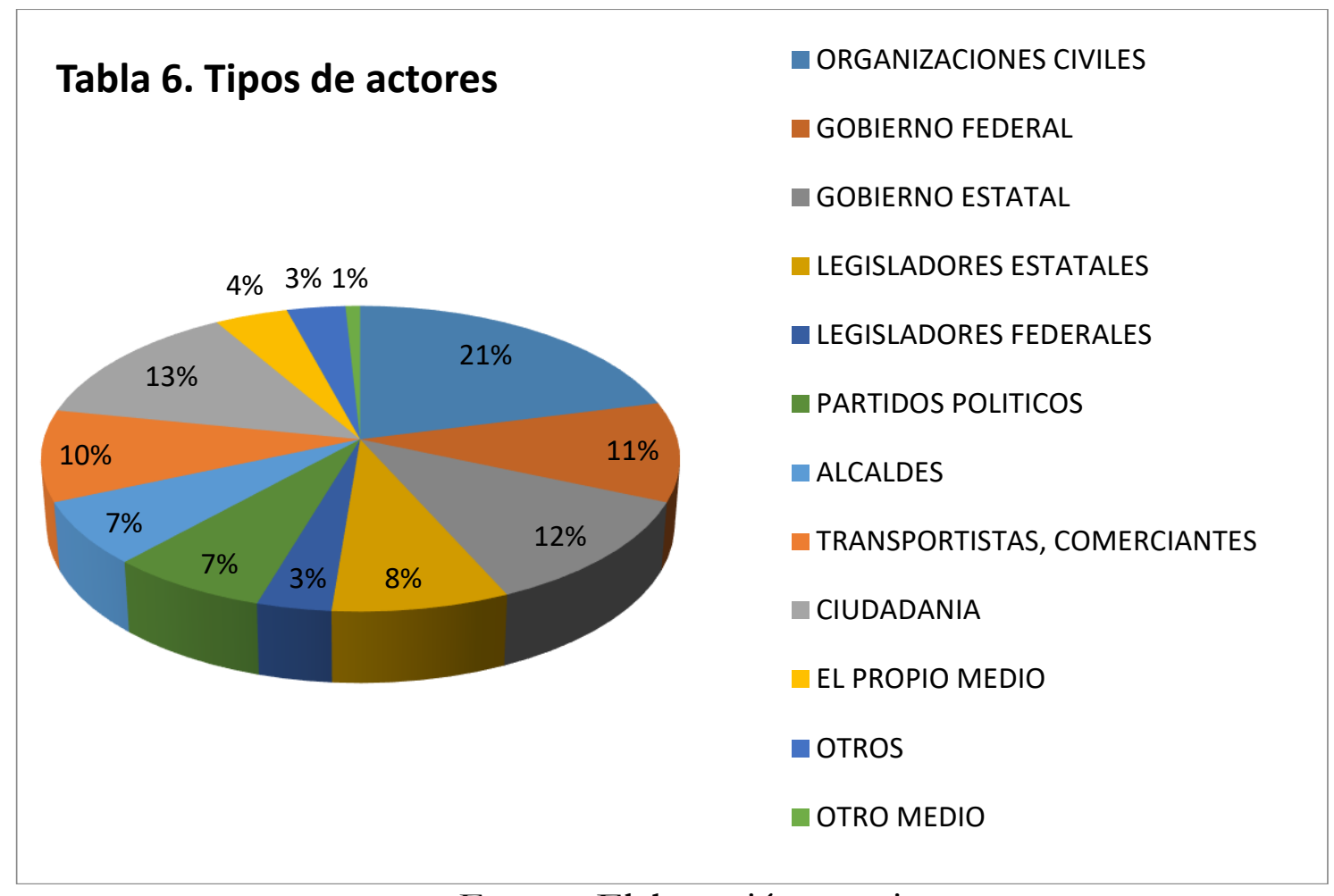

Fuente: Elaboración propia

Por lo que se refiere a cada una de las categorías de actores; la de organizaciones civiles muestra como mayor actor en el discurso mediático al colectivo Congreso Nacional Ciudadano (13 menciones). La figura del gobierno federal con mayor presencia (6 menciones) es compartida por el presidente del país, Enrique Peña Nieto, y el secretario de hacienda, José Antonio Meade. El actor de mayor presencia en la categoría de gobierno del estado es el Gobernador Jaime Rodríguez Calderón (14 menciones), seguido del vocero de seguridad pública, Aldo Fasci (9 menciones). 
El legislador estatal con mayor presencia mediática en el corpus analizado es Samuel García, de Movimiento Ciudadano (9 menciones). Los legisladores federales, por el contrario, aparecen en igual cantidad de ocasiones cada uno de los 8 identificados. El alcalde con mayor frecuencia en la categoría fue Víctor Fuentes, presidente municipal de San Nicolás (6 menciones).

Por lo que se refiere a la categoría de Partidos Políticos, en ella fueron incluidos sus dirigentes nacionales y estatales, así como miembros afiliados. En dicha clasificación aparece de manera más constante el PRI (7 menciones), seguido en igual proporción por el PRD y el PT (6 menciones respectivamente).

Es importante señalar que del análisis cuantitativo de los actores se eligieron, para una segunda fase de investigación, las redes sociales de aquellos que mayores menciones reflejan. Esto con la intención de analizar el desarrollo del asunto y la controversia en los espacios digitales, encaminados a conocer la dinámica que siguió el objeto de estudio en escenarios múltiples.

\section{Conclusiones}

El gasolinazo se convirtió en un asunto de interés público, y gran visibilidad mediática gracias al origen cargado de sensibilidad que tuvo esta controversia, y a la evocación de un imaginario común entre la ciudadanía.

Los neoloneses, a través del movimiento que se llevó a cabo en la ciudad, lograron alcanzar la visibilidad necesaria para presentar su postura de desacuerdo ante el incremento al precio del combustible mediante el relato que presentaron los medios de comunicación.

Sin embargo, este estudio observa cómo una vez que la controversia entra en la agenda mediática, el relato puede ser manipulado de acuerdo a los intereses perseguidos por las empresas de comunicación. Es entonces en esta dinámica donde influyen los intereses, y valores que determinan la postura de los actores en cualquier controversia, cuando 
los medios de comunicación pasan de ser una herramienta a ser un actor por sí mismos.

Finalmente, el corpus recabado para este estudio nos muestra que en el proceso de producción informativa muchos de los medios tradicionales encuentran su principal insumo, en archivos (textuales, visuales o audiovisuales) que circulan entre los usuarios de redes sociales. Esto como parte de la tendencia general hacía la convergencia digital, lo que nos presenta la necesidad de ampliar la investigación a estos espacios virtuales.

\section{Referencias}

Castells, Manuel (Marzo, 2008) The New Public Sphere: The Global Civil Society, Communication Networks, and Global Governance.

ANNALS of the American Academy of Political and Social Science. Vol. 616, Issue 1, pp. $78-93$. https://doi.org/10.1177/0002716207311877

Dewey, J. (2004). La opinión pública y sus problemas. M 



\title{
Las redes sociales en la esfera pública como escaparate de problemáticas sociales
}

\author{
Margarita Emilia González Treviño \\ Hiram Garrido Ledezma
}

Resumen: México vivió uno de los sucesos de mayor inflación respecto al precio de la gasolina al iniciar el año 2017, dándose un aumento en el precio de este combustible muy considerable, razón que provocó el descontento generalizado de la sociedad causando una gran controversia social y mediática en el ámbito de la esfera pública.

Ante tal panorama distintos actores políticos y sociales de la vida nacional fueron emisores de múltiples comentarios a la opinión pública, algunos defendiendo o justificando la medida y otros con una postura contraria y quizá buscando un posicionamiento en el ámbito político.

Dichos personajes usaron las redes sociales para difundir sus diversos mensajes y plantar sus ideas ante sus seguidores, sin embargo, el uso de estas plataformas digitales no fue hecho de la misma manera por todos y además causó impacto como algunos de ellos lograron penetrar más en la esfera pública de la que se habla incluso sin tener una actuación predominante en el escenario mediático real nacional.

Palabras clave: Gasolinazo, redes sociales, controversia, esfera pública.

Abstract: Mexico experienced one of the most inflationary events with respect to the price of gasoline at the beginning of 2017, giving rise to an enormous increase in the price of this fuel, a reason that caused the 
general discontent of society causing great social controversy and media in the sphere of the public sphere.

Against this background, different political and social actors of the national life were emitters of multiple commentaries to the public opinion, some defending or justifying the measure and others with a contrary position and perhaps looking for a position in the political sphere.

These characters used social networks to disseminate their various messages and plant their ideas before their followers, however the use of these digital platforms was not done in the same way by all and also caused an impact as some of them managed to penetrate more into the sphere public which is even spoken without having a predominant performance in the national real media scene.

Keywords: Gasolinazo, social networks, controversy, public sphere.

\section{Introducción}

— L 2017 inició en México con uno de los casos que más contemporánea de la historia del país, y esto fue ocasionado por el aumento desproporcional del precio de la gasolina, fenómeno que fue conocido como el gasolinazo. Dicho suceso en términos actuales causó una viralización por la inconformidad y mal estar social que provocó, sobre todo en un estrato social medio, quienes se sintieron vulnerados ante tal aumento.

La esfera pública de la democracia se alimenta de la relación que existe entre los medios de comunicación, la ciudadanía y la sociedad, misma que se da en estados de democracia, donde se adquiere el derecho a la palabra pública, que interrelaciona las luchas por la visibilidad, el reconocimiento y la credibilidad (Bonilla-Vélez, 2006).

Ante tal escenario, las actuales tecnologías de la información y la comunicación (TIC) tuvieron un rol importante en el actuar de la esfera pública, desde la perspectiva de actores influenciadores de opinión 
como políticos y representantes de instituciones ciudadana, como de la ciudadanía que llamaremos la audiencia o público consumidor de información.

El desarrollo de estas plataformas digitales, como las redes sociales ha maximizado el valor de la conversación entre los individuos y la interacción que puede haber entre diversas audiencias (Lorente, 2011; Arrojo, 2013).

Por otra parte, si tomamos en cuenta la premisa de que las redes sociales representan un nuevo entorno y un nuevo soporte comunicativo con los ciudadanos y las organizaciones en un modelo de comunicación en todas direcciones, pero con el compromiso de interactuar, de que exista retroalimentación dentro de los nichos virtuales a los que uno decida libremente estar. La red es global, pero se forma de sub-redes en las que cada miembro decide a quien acepta en su grupo de interlocutores para interactuar entre ellos. (Túñez \& Sixto, 2011).

Una de las teorías en que nos apoyaremos para estudiar el impacto de las redes sociales virtuales será la teoría de los seis grados, descrita por el sociólogo Duncan Watts (en Hütt, 2012, p. 123); esta "expone que la mayoría de las personas mantienen un vínculo directo, más o menos permanente con alrededor de 100 personas. Estas, las cuales se van restando o sumando a lo largo de nuestras vidas, viene a consolidar una lista de 100 a 200 personas aproximadamente en nuestra lista. Si estos 100 contactos nos presentaran a sus 100 respectivos contactos, nuestra lista de referencia iría creciendo exponencialmente. Es decir, en un primer nivel tendríamos 100 personas, y si cada uno de ellas nos presenta a sus 100 respectivos contactos, tendríamos 10.000 integrantes en nuestra lista, y así sucesivamente hasta llegar a nuestro sexto nivel, con un total de 1 billón de personas (un millón de millones)".

Si este modelo descrito de red es usado por personajes o equipos políticos, puede llegar a ser una herramienta de difusión, promoción de ideas y obtención de datos que ya ha sido utilizado y comprobada su eficiencia, cuando estas redes son gestionadas de manera adecuada y 
bajo una estrategia on-line vinculada con la estrategia off-line, donde ninguna es más o menos importante que la otra.

Finalmente, Espino-Sánchez (2014) menciona que estos grupos lograron ser populares porque eran ciudadanos, no partidistas.

\section{El impacto que tienen las redes sociales virtuales}

El impacto puede considerarse como salones o espacios digitales "donde se desarrolla la deliberación pública, la formación de una opinión pública crítica y racional y un diálogo recíprocamente ilustrado entre participantes en pie de igualdad" (Freelon en Valera, 2012).

Gibson y Römmele en Valera (2012) señalan que el protagonismo de las plataformas digitales en fenómenos de formación de opinión y de activismo social y político, aunado a la duración del modelo elitista de comunicación mediática, ha provocado el debate sobre el impacto de la comunicación digital sobre las formas y prácticas políticas de las democracias occidentales. También menciona que "existe cierto acuerdo académico en torno al hecho de que el desarrollo de la Web 2.0 ha impulsado notablemente la ampliación de los canales de comunicación ‘bottom-up' en los procesos de comunicación política.

Montero y Turiera-Puigbò en Valera (2012) coinciden respecto a este protagonismo que tienen las redes virtuales, especialmente en periodos electorales.

Las nuevas generaciones se consideran como nativos digitales, por lo cual desarrollan grandes lazos de identidad con Internet. A esta generación de nativos digitales las redes sociales influyen profundamente en una buena parte de la vida psicológica de estos usuarios. Esta identidad del usuario se expresa en el perfil que elabora para sus redes sociales de Internet, es decir la descripción que ellos mismos hacen de sus interés o usos (Espino-Sánchez, 2014).

Las redes sociales, hoy, son ejemplos ideales para hacer periodismo, o, por lo menos, buscar y desarrollar contenidos que puedan cambiarse en noticia. Entre los espacios de las redes sociales que se sobresalen, 
están los espacios de la blogósfera, formado por los blogs, sitios como el YouTube y micro blogs (Twitter), así como sitios de relacionamiento, como Facebook y Google+ (Porto Renó, 2011).

Sin embargo, tomando en cuenta que Twitter es un canal de comunicación inmediato, que es usado por políticos y en este caso candidatos, para dar respuesta a periodistas, acallar rumores $\mathrm{O}$ establecer una postura referente a algún tema polémico o algún tema que permita generar relevancia a su postura política (Sandoval Almazán, 2012).

Actualmente la sociedad tiende a organizarse en redes de comunicación virtuales interconectadas, como ya lo hemos visto apoyados en la teoría de los seis grados de separación de Watts, con una progresión de participación que evoluciona en escala geométrica, sin embargo, sus representantes políticos apenas han comenzado a utilizar la red para propiciar el contacto interpersonal con sus administrados (Túñez \& Sixto, 2011).

Echevarría (2012) afirma que la televisión sigue siendo el medio de comunicación política más recurrido, sin embargo, el internet 2.0 es utilizado como una fuente paralela y complementaria para la actual generación digital, que utiliza estas plataformas no solo para mantenerse informado, sino para generar opiniones y participar de manera activa en los movimientos sociales a través de la red.

\section{Objetivos y metodología}

Como principal objetivo de este estudio fue evidenciar el rol de los principales actores político-sociales de México y cómo eran los mensajes que elaboraban ante la controversia que se suscitó en la sociedad mexicana ante la medida del aumento de la gasolina anunciada a finales del año 2016.

Para esto se tenía identificados quiénes eran precisamente estos actores, gracias a un análisis de contenido realizado previamente en medios tradicionales locales y nacionales (ver capítulo "El gasolinazo en los medios tradicionales"). Estos eran Jaime Rodríguez Calderón, 
apodado "El Bronco", gobernador independiente de Nuevo León, Samuel García, en ese momento diputado local del estado de Nuevo León por el partido Movimiento Ciudadano, Gilberto Lozano, fundador del denominado Congreso Nacional Ciudadano, Enrique Peña Nieto, Presidente de México y José Antonio Meade, quien fuera para ese entonces Secretario de Hacienda y Crédito Público del país.

De tal manera se procedió a identificar en el mismo rango de fechas que comprendió de 15 de diciembre de 2016 al 15 de febrero de 2017 los mensajes de estos personajes en sus redes sociales, donde se eligieron Facebook, por ser la red social más empleada por las personas en México y Twitter, ya que, si bien es la tercera red con más uso por los mexicanos, es la red que tiene un uso predominantemente por los personajes políticos (AMIPCI, 2017).

Una vez recolectados los post de Facebook y los tuits de Twitter de estos personajes en dicho rango de fechas se procedió a hacer un análisis de contenido como técnica de recolección de datos.

La información recabada para Facebook fueron los datos de identificación del post, es decir la fecha en que fue publicado y por quién, el hecho que narraba, es decir el mensaje en sí, si el mensaje era propio o era un post compartido de la red social de algún otro personaje o institución, también si en el mensaje se etiquetaba a algún otro personaje o institución, el número de reacciones que dicha plataforma muestra como son el me gusta, me encanta, me divierte, me sorprende, me entristece y me enoja, por último en número de veces que el post fue compartido y el números de comentarios que generó y cómo eran estos mismos, si eran favor, en contra o indefinidos.

Por su parte de los tuits de Twitter se analizaron los datos de identificación como en el caso de Facebook la fecha de publicación del tuit y por cuál de los personajes, el hecho que narraba, si era mensaje propio o un retuit de otro personaje o institución, si se etiquetaba a algún otro personaje o institución, así como el número de favoritos, compartidos y comentarios que generó el tuit y cómo eran estos, si eran a favor, en contra o indiferentes. 


\section{Resultados}

Tras la recopilación de datos en las plataformas digitales, el total de post y tuits entre los cinco personajes seleccionados para hacer el análisis de contenido fue de 99 de estos 69 fueron post de Facebook $(68.31 \%)$ y el resto, es decir 30 fueron tuits (29.7\%).

La distribución proporcional de los mensajes entre cada uno de los personajes en estudio fueron: el diputado local de Movimiento Ciudadano Samuel García público en su red social de Twitter 21 tuits y en su página de Facebook 30 post en el rango de estudio que se tomó en cuenta en esta investigación y mensajes que tienen referencia a algo sobre el gasolinazo, por su parte el Presidente de México Enrique Peña Nieto publicó 8 post de Facebook y 7 tuits en Twitter, Jaime Rodríguez Calderón, Gobernador de Nuevo León tuiteó 1 tuit, 12 post en Facebook, el activista ciudadano Gilberto Lozano publicó 16 post en su página personal de Facebook y 1 tuit en Twitter y por último el ex Secretario de Hacienda José Antonio Meade publicó únicamente 3 post en Facebook, no teniendo ninguna participación en su Twitter (ver tabla 1).

Tabla 1: Distribución de publicaciones en redes sociales por personajes entre el 15/12/2016 y el 15/02/2017.

\begin{tabular}{|c|c|c|}
\hline Personaje & $\begin{array}{l}N^{\circ} \text { de post en } \\
\text { Facebook }\end{array}$ & $\begin{array}{l}N^{\circ} \text { de tuits en } \\
T_{\text {witter }}\end{array}$ \\
\hline Samuel García & 30 & 21 \\
\hline Jaime Rodríguez Calderón & 12 & 1 \\
\hline Enrique Peña Nieto & 8 & 7 \\
\hline Gilberto Lozano & 16 & 1 \\
\hline José Antonio Meade & 3 & 0 \\
\hline Total & 69 & 30 \\
\hline
\end{tabular}

Fuente. Elaboración propia

Por otro lado, del total de publicaciones que hicieron los personajes en estudio, Samuel García hizo 29 de origen propio 22 fueron compartidas; Enrique Peña Nieto hizo 11 de origen propio y 4 fueron compartidas, Jaime Rodríguez Calderón hizo 9 de origen propio y 4 
compartidas, Gilberto Lozano hizo 13 de origen propio y 4 compartidas y de las 3 publicaciones de José Antonio Meade 1 fue de origen propio y 2 fueron compartidas.

Algo importante de notar fue el impacto en respuesta del público seguidor de cada uno de estos personajes ya que en algunos casos fueron varias centenas de comentarios los que cada uno de estos mensajes provocaba, señal de la controversia que el caso en cuestión generaba en el escenario público mexicano.

A este respecto los comentarios totales generados en sus redes por cada uno de los personajes en estudio queda de la siguiente manera: Samuel García obtuvo 10,508 comentarios en su página de Facebook mientras que en su cuenta de Twitter tan solo obtuvo 40 comentarios; Enrique Peña Nieto tuvo 66,115 comentarios de seguidores en Facebook y 1,625 en Twitter, Jaime Rodríguez Calderón tuvo 22,728 comentarios en Facebook y 296 en Twitter; Gilberto Lozano tuvo 34,643 comentarios en Facebook y ninguno en Twitter y por último José Antonio Meade tuvo 202 comentarios en Facebook y 42 en Twitter. El total de comentarios hechos por seguidores entre las dos redes sociales seleccionadas para el estudio fue de 136,199 (ver Tabla 2).

Tabla 2: Distribución de comentarios por personaje en redes sociales

Personaje

$N^{\circ}$ de comentarios en

Facebook

Samuel García

Jaime Rodríguez Calderón

Enrique Peña Nieto

Gilberto Lozano

José Antonio Meade

Total

$\begin{array}{ll}10,508 & 40 \\ 22,728 & 296 \\ 66,115 & 1,625 \\ 34,643 & 0 \\ 202 & 42 \\ 134,196 & 2,003\end{array}$

Fuente. Elaboración propia
$N^{\circ}$ de comentario en Twitter 40 296 , 625 2,003

Por otro lado un elemento más que es trascendente destacar en el contexto de la controversia causada por el caso del gasolinazo fueron el número de veces que las publicaciones hechas por los personajes en 
estudio tuvieron, ya que refleja el interés e impacto de la sociedad digital respecto al tema, quedando distribuido de la siguiente manera: Samuel García recibió 222,596 comentarios de seguidores en sus redes sociales, Enrique Peña Nieto obtuvo 43,633 comentarios en sus redes sociales; Jaime Rodríguez Calderón recibió 32,529 comentarios en sus redes sociales, Gilberto Lozano obtuvo 155,040 comentarios entre su Facebook y cuenta de Twitter y finalmente José Antonio Meade acumuló 1,334 comentarios de seguidores entre su página de Facebook y cuenta de Twitter (ver Tabla 3).

Tabla 3: Distribución de comentarios de seguidores en redes sociales por personaje.

\begin{tabular}{l|rr} 
Personaje & $\begin{array}{c}N^{\circ} \text { de veces de } \\
\text { post compartidos }\end{array}$ & $\begin{array}{l}\boldsymbol{N}^{\circ} \text { de veces de tuits } \\
\text { compartidos }\end{array}$ \\
\hline Samuel García & 221,462 & 134 \\
Jaime Rodríguez & 31,572 & 957 \\
Calderón & & \\
Enrique Peña Nieto & 34,770 & 8,863 \\
Gilberto Lozano & 154,921 & 119 \\
José Antonio Meade & 1,142 & 192 \\
Total & 443,867 & 10,265
\end{tabular}

Fuente. Elaboración propia

\section{Conclusiones}

Sabemos del potencial que tiene Internet (Peñamarín, 2014) y por ende las plataformas digitales de comunicación para contribuir a la expansión de la esfera pública, ya que son los mismos participantes o usuarios de estas plataformas quienes interpretan a internet como un espacio público.

A este escenario es interesante observar el grado de participación y activismo político y ciudadano que originó el tema de gasolinazo, desde el 27 de diciembre de 2016 fecha en que fue anunciada oficialmente la medida por el gobierno de México, e incluso desde días antes de oficializarse esta noticia y al menos hasta el día 15 de febrero de 2017, fecha en que concluyó el rango de tiempo de este estudio, pero incluso 
podríamos decir que es un tema que sigue en el imaginario social de los mexicanos ya que semana tras semana el precio de este hidrocarburo continúa aumentando e incluso fue un tema mencionado dentro de los mensajes del $6^{\circ}$ Informe de Gobierno del Presidente como importante o que resaltó las causas y efectos de esta controversia.

También resulta interesante ver dentro de los resultados los 5 actores político-sociales que se identificaron por su participación en medio de comunicación tradicionales, entre ellos tres altos funcionarios públicos el Presidente de México, que simplemente por su nivel de responsabilidad en el problema se pudiera entender el involucramiento que tuvo, un secretario de estado, en este caso el de Hacienda y Crédito Público quien al menos en redes sociales tuvo baja participación, siendo él el señalado como autor intelectual del gasolinazo y un gobernador de un estado importante de la República quien criticó fuertemente la medida, a sabiendas de que era un asunto impopular entre la población y que le podía ayudar en su imagen ante la que en ese momento era una virtual candidatura a la presidencia de México, que sabemos finalmente ocurrió. También está el caso en el mismo sentido de quizá encontrar o crear una buena imagen en cara a una probable candidatura del caso del diputado local de Nuevo León por Morena quien tomara esta acción de protesta como eje principal de su campaña de comunicación política posteriormente al ser candidato a una senaduría por el mismo estado y finalmente el caso de un activista social-político, que como se dice 'subiéndose a la ola' quiso aprovechar la coyuntura para observar si el uso de manifestación de esta controversia le valían para postularse en algún cargo de elección popular.

Otra punto interesante de observar en el ámbito de la comunicación y marketing político es el grado de penetración e impacto que tiene la red social Facebook entre los políticos que las usan, como de los mismo seguidores, viéndose que más del doble de los mensajes sobre el asunto que causó esta controversia eran expresados por Facebook que por Twitter, esto evidencia también como la construcción de mensajes cortos y que a la vez conllevan un mayor grado de complejidad para su construcción y entendimiento no es tan aceptado entre el público y políticos mexicanos. 
Algo más que resulta importante señalar es el grado de respuestas que tuvieron los personajes en estudio, ya que en el ámbito de la comunicación política online, la interacción que se da entre quien origina el mensaje, un político o institución pública con la ciudadanía, es el inicio de una actitud política denominada compromiso político online. Se podría decir que el nivel de importancia de su puesto y el uso que le dan a sus redes sociales es lo que los llevaría a tener una mayor respuesta por parte de los seguidores y casi sucedió, siendo por ejemplo el presidente Peña Nieto quien más comentarios generó en su página de Facebook; sin embargo Gilberto Lozano, tan solo como activista y presidente de una organización ciudadana, consiguió obtener más retroalimentación de sus publicaciones por encima de Jaime Rodríguez, quien desde su campaña a la gubernatura de Nuevo León empleó ampliamente estas plataformas o Samuel García, quien como dijimos centró su eje de comunicación en esta acción de inconformidad para la Administración federal actual.

Respecto a los comentarios que vertían los seguidores de los personajes de estudio y respecto al tema del gasolinazo, es importante mencionar que las mayorías de estos mensajes que se observaron fueron en contra o con un grado de connotación negativa.

Finalmente otro elemento que aporta a la participación ciudadana y a la difusión y propagación de los mensajes políticos en redes sociales es el número de veces compartidas dichas publicaciones y nuevamente sorprende el hecho de que quien menos proyección tuvo en una línea previa de tiempo en medios tradicionales como digitales fue quien tuvo el segundo lugar de compartido en sus mensajes por sus seguidores, superando los 150 mil compartidos entre sus posteos de Facebook y en primer lugar fue Samuel García, con más de 220 mil compartidos entre sus publicaciones de Facebook, notándose que no necesariamente existe una correlación entre su jerarquía política y el número de penetración que tienen con la sociedad.

Sería interesante notar en futuros estudios como los políticos hacen uso de estas herramientas de comunicación no para formar una imagen pública o defenderse del juicio público de la ciudadanía, sino para la 
difusión real de ideas o propuesta, así como la propagación efectiva de programas o planes institucionales que ayude a su vez a incrementar el grado de cultura política que existe entre los ciudadanos de México.

\section{Referencias}

Asociación Mexicana de Internet (2017) Hábitos de los usuarios de Internet en México.

Arrojo, M.J. (2013) La televisión social. Nuevas oportunidades y nuevos retos para el sector audiovisual, en Actas del I Congreso Internacional de Comunicación y Sociedad Digital, La Rioja

Bonilla-Vélez, J.I. (2006) Medios, esfera pública y ciudadanía ¿qué políticas de comunicación para cuál sociedad? Anagramas Rumbos y Sentidos de la Comunicación, vol. 4, núm. 8, enerojunio, 2006, pp. 41-52

Espino-Sánchez, G. (2014). La política en internet, ¿de la mediatización a la convergencia digital? Convergencia Revista de Ciencias Sociales, (65) pp.39-63

Hüt Herrera, H. (2012). Las redes sociales: Una nueva herramienta de difusión. Reflexiones, 91 (2) pp. 121-128.

Peñamarín, C. (2014) Esfera pública y construcción del mundo común. El relato dislocado. CIC. Cuadernos de Información y Comunicación, vol. 19, enero-diciembre, 2014, pp. 103-124

Porto Renó, D. (2011). Periodismo, redes sociales y transmediación. Razón y Palabra, (16).

Sandoval Almazán, R. (2012). You'Tube, Facebook y Twitter en la campaña electoral mexicana del 2012: un análisis mixto. En XVII Congreso Internacional del CLAD sobre la Reforma del Estado y de la Administración Pública. Cartagena, Colombia. 
Túñez, M. \& Sixto, J. (2011). Redes sociales, política y Compromiso 2.0: La comunicación de los diputados españoles en Facebook. Revista Latina de Comunicación Social (66) pp. 210-246.

Valera Ordaz, L. (2012). ¿Deliberación 2.0 o radicalización de la retórica partidista? Un análisis de las discusiones políticas en los muros de Facebook de candidatos políticos españoles. Textual \& Visual Media, 5. pp. 311-340 



\title{
Esfera pública y economía política de la comunicación. El caso del gasolinazo en Monterrey
}

\author{
Juan Antonio Garza Sánchez \\ Daniela Mendoza Luna
}

Resumen: El presente capítulo aborda los antecedentes de los medios masivos de comunicación que se estudiaron en la investigación denominada: Esfera Pública y Economía Política de la Comunicación. El caso del Gasolinazo en Monterrey; Así como las entrevistas realizadas a líderes de opinión y representantes de los medios analizados. Dicha investigación fue apoyada por el PAICYT-UANL 2018 y realizada durante el Verano de la Investigación Científica UANL. En el proyecto estuvieron vinculados cinco profesores y siete estudiantes de licenciatura, uno de maestría y uno de doctorado de la Universidad Autónoma de Nuevo León.

Palabras Clave: historia de los medios, economía política de la comunicación, medios de comunicación.

\begin{abstract}
:
This chapter deals with the antecedents of the mass media that were studied in the research called: Public sphere and Political Economy of Communication. The case of Gasolinazo in Monterrey; As well as the interviews made to opinion leaders and representatives of the media analyzed. This research was supported by the PAICYT-UANL 2018 and carried out during the UANL Summer of Scientific Research. The project involved five professors and six undergraduate students, one
\end{abstract}


of a master's degree and one of a doctorate from the Universidad Autónoma de Nuevo León.

Keywords: History of the media, political economy of communication, media.

\section{Introducción}

COMO industrias culturales, los medios de comunicación son organizaciones complejas, actores económicos que se articulan con otras instituciones y son parte constitutiva de las estructuras de poder de la sociedad contemporánea. Su análisis exige un punto de vista interdisciplinario a través de la Economía Política de los Medios de Comunicación (EPM).

Mosco (2006) define la EPM como el estudio de las relaciones sociales, particularmente las relaciones de poder, que mutuamente constituyen la producción, distribución y consumo de recursos, incluidos los recursos de comunicación.

Solo mediante la comprensión de papel individual que juegan las empresas de medios como entidades de negocios se puede apreciar plenamente su forma de operar en el seno de la sociedad. En este sentido nuestro conocimiento de la economía de los medios refuerza nuestra comprensión de papel y funciones que los medios de comunicación de masas desempeñan en la sociedad. (Albarrán, A 1999, p. 19)

Reflexionar sobre el fenómeno de la controversia mediante la manifestación social conocida como "Gasolinazo" durante los primeros días de enero de 2017 en México, debe contar con un acercamiento hacia los medios de comunicación que le dieron cobertura, tanto a nivel nacional, como en el plano local en donde se centra el presente análisis.

Es entonces menester hacer un breve recorrido por el surgimiento de estos medios de comunicación mexicanos; sus dueños, y el papel que ocupan en ciertos conglomerados nacionales, así como el alcance y penetración con el que cuentan en el momento en que se desarrolla la 
protesta social derivada del incremento al precio de la gasolina en México.

...la etapa que hoy viven los medios masivos de comunicación mexicanos, se encuentra completamente inmersa en las lógicas del capitalismo, concebidos como instrumentos para la acumulación de riquezas más que como los verdaderos elementos democratizadores capaces de potenciar el desarrollo social de México. (Campos 2013, pág. 62)

La elección de los entrevistados del presente capítulo está relacionada con el alcance en redes sociales y medios de comunicación tradicionales que estos personajes tuvieron a través de su opiniones, comentarios y notas durante el periodo de mayor controversia por el tema del Gasolinazo.

Destacan líderes de opinión, periodistas y titulares de las jefaturas de información de los distintos medios que se utilizaron para el presente análisis.

\section{Líderes de opinión}

En primera instancia, señalaremos a los líderes de opinión, en este caso, al senador (en ese entonces diputado local) por el partido Movimiento Ciudadano, Samuel García y al activista Gilberto Lozano, de la organización denominada Congreso Nacional Ciudadano, por formar parte del grupo seleccionado con anterioridad, como personas que tuvieron una actividad importante según el análisis de contenido y especialmente por sus interacciones en las redes sociales que son señaladas en el capítulo anterior: Las redes sociales en la esfera pública como escaparate de problemáticas sociales.

La definición tradicional de líder de opinión se deriva de la Teoría de los Dos Pasos, acuñada por Paul Lazarsfeld y Herbert Menzel (1975), quienes aseguraban que el sistema comunicativo y la influencia de los medios tenía como primer paso el mensaje, pero este era recibido por un tipo de persona, el líder de opinión. 
...la influencia no va directamente de los medios al individuo, sino que llega a la mayoría de las personas a través de un pequeño grupo de personas informadas que filtran las noticias, loc llamados líderes de opinión (Chaffee y Hernández Ramos en Lozano 2007, p.28).

Según la propia definición de Lazarsfeld, el líder de opinión tiene ciertas características importantes; debe ser carismático, reconocido y funcionar como representante de ese grupo. Un auténtico líder de opinión, además, debe de conocer los asuntos de forma profunda y especializada.

Pero además necesita comunicar de forma eficaz sus ideas y mensajes, por lo que debe utilizar argumentos directos y poco formales para llegar al mayor número de personas y lograr la empatía de los miembros de su grupo.

González (2010) aporta un concepto revisado del líder de opinión, una reconsideración de la Teoría de los Dos Pasos en el contexto digital e interaccional actual, que vale la pena tener en cuenta.

La propuesta que se hace aquí es la consideración de un nuevo paso en el flujo de la comunicación: el Three-Step Flow, en el que la información de los medios tradicionales es recogida y procesada por los líderes de opinión, quienes la distribuyen entre sus seguidores a través de pseudomedios de comunicación como pueden ser sus blogs o sus páginas personales de las nuevas redes sociales de Internet. (González 2010)

En esta propuesta el proceso de comunicación fluye primero de los medios a los líderes; a sus propios medios administrados por ellos, y de ahí a los ciudadanos reciben los contenidos a través de esos medios.

\section{Samuel García Sepúlveda Senador Movimiento Ciudadano}

"Se me empezó a calificar como el diputado del IEPS o el diputado del gasolinazo o el chavo del gasolinazo y le ha sacado mucho jugo" 
Consciente de que la "bandera" del gasolinazo lo catapultó en el conocimiento del electorado, el senador electo, Samuel García, afirmó que este tipo de temas mueven a la gente porque "le pegan en el bolsillo".

Con solo 31 años de edad Samuel García Sepúlveda logró catapultar su carrera política hasta el Senado de la República tras haber debutado en la función pública como diputado local de Movimiento Ciudadano en el Congreso de Nuevo León, durante la Septuagésima Cuarta Legislatura.

En entrevista explicó que este gran "brinco" en su trayectoria fue ocasionado por un tema que ha ostentado como bandera de campaña desde que comenzó a incursionar en la política: eliminar el "gasolinazo".

Esto debido a que su vocación como abogado fiscalista lo llevó a profundizar en las causas del aumento en el precio de la gasolina a partir del 2009, cuando comienzan a incorporarse gradualmente impuestos al precio de los combustibles. Situación que finalmente estalló en una protesta masiva en Monterrey el pasado 5 de enero del 2017, por el hartazgo ciudadano.

Durante estos nueve años, dice, se ha percatado de que existen vacíos legales en la forma en que se realizó el incremento, lo cual le ha permitido promover y ganar juicios de amparo a lo largo del país. "Yo aproveché que, siendo abogado fiscalista, yo tengo ya litigando en materia fiscal pues más de 8 años y cuando entré a la Firma (de abogados) una ventaja que yo encontré, y fue una manera de hacer buen negocio, era asesorar y amparar gasolineros.

"Yo vi que los gasolineros están muy apretados en su margen (de ganancia) ellos cobraban solamente un 8 (por ciento); Pemex no les consideraba la merma que hay durante el flete y ahí el gasolinero pierde mucho entonces yo empecé a amparar gasolineros", dice. 
Conforme fue estudiando más sobre el tema encontró nuevas inconsistencias en el aumento de la gasolina, que --contrario a lo que la gente piensa - no fue ocasionado por la reforma energética que impulsó el presidente priista Enrique Peña Nieto, sino por un sistemático aumento en los impuestos que data desde el gobierno del panista Felipe Calderón.

"En el 2009 Calderón batalló mucho con los gobernadores porque la mayoría eran del PRI entonces la CONAGO (Conferencia Nacional de Gobernadores) lo traía 'en friega' decían: "quiero lana, quiero lana”. Entonces Calderón 'bien vivo' dice: 'Mira, voy a crear un impuesto a la gasolina y ese te lo quedas tú (Estado) pero como ya nada más me quedan cuatro años o cinco de gobierno es impuesto vence en el 2012", detalló Sepúlveda con el acento norteño y franco que lo ha caracterizado.

A partir de entonces la cuota Estatal se sumó al impuesto Federal agregando 2.30 pesos aproximadamente al costo del combustible. Y aunque esta cuota debía eliminarse en el 2012, con el gobierno entrante de Enrique Peña Nieto se mantuvo.

Destaca que, a partir del sexenio de Peña Nieto, con Luis Videgaray Caso y José Antonio Meade Kuribreña como ex secretarios de Hacienda y Crédito Público, se incluyó el Impuesto Especial sobre Producción y Servicios (IEPS) al precio del combustible.

"Meade y Videgaray empiezan a estudiar el impuesto federal y dicen: 'oye pues sí el petróleo empieza a bajar y el IEPS es una tasa y como quiera el precio final siempre es el mismo y va a estar muy bien, porque como el precio es el mismo, si el petróleo baja el IEPS sube'. Entonces dejaron el impuesto correr.

"Ahí es cuando empieza mi crítica, al decir: 'Oye, pues no friegues, si el barril bajo de $\$ 129$ a $\$ 22$ y la gasolina es 5 veces más barata debería ser también la venta más barata. Pero ellos, jugando con la ecuación, conforme disminuía (el precio de) la gasolina crecía el IEPS”, señala. 
Después, a partir del 2016 es cuando entró en vigor una nueva reforma que congeló el impuesto y en lugar de ser un gravamen variable, quedó estático.

"La tasa la hicieron una cuota y te ponen en la Ley: independientemente del precio (del combustible) siempre vas a pagar 4.5 pesos de impuestos', y argumentando que ya con la reforma energética el precio está libre, dicen: 'tú cobra lo que quieras pero de litro yo te voy a vender la gasolina más 4.5 de impuesto Federal, más los 40 centavos estatales' y dicen hoy aparte: 'como ya firmamos el convenio de Kioto y tenemos que controlar las emisiones de CO2 vamos a crear un impuesto verde', y crean el combustible fósil; otros 18 centavos por litro", explica.

En este sentido, dijo, ahora se le agrega al precio final del consumidor el costo del flete, la administración, la importación y tres impuestos, que además está prohibido por ley desglosarlos en el recibo, de manera que el desconocimiento sobre lo que las personas pagan es generalizado.

Fue en este punto cuando encontró un área de oportunidad para informar a la ciudadanía sobre lo que estaba sucediendo con fenómeno denominado "gasolinazo" e impulsar el tema en la agenda pública.

"Definitivamente entre más generalizado y entre más agravia a la gente un tema, es más fácil de subir a la agenda pública. Y obviamente en México, que no existe un buen transporte público, la mayoría de los mexicanos se ven obligados a comprar un coche. En México el carro es una obligación más que una opción, por lo tanto, todos deben de surtirse de gasolina y ese gasto que es ridículo y excesivo a todos los mexicanos nos duele sin importar tu nivel socio económico.

"El que el que veas a diario que en Estados Unidos el 'gringo' paga con 11 dólares el tanque y aquí te echas si traes un Sedán 700, 900 pesos o si traes una camioneta arriba de mil pesos. Con lo mal que está la economía pues es un tema que duele mucho", dijo. 
Las plataformas que ha utilizado para hablar sobre estos temas han sido principalmente electrónicas, vía redes sociales, aunque también a través de los medios tradicionales ha logrado impulsar la difusión mediante iniciativas de reforma a la ley presentadas ante el Congreso local.

"A mí Samuel García realmente han sido tres los temas que me han catapultado: gasolinazo, eliminación del fuero y la participación ciudadana incluyendo revocación de mandato. Realmente para mí los tres son igual de importantes, pero aquí es donde uno se da cuenta que a la gente lo que más le molesta es su bolsillo.

"Más que meter a la cárcel a un corrupto, más que empoderarlos, es: 'si yo mexicano que ganó 10 mil pesos al mes me quitas 3 mil en llenar mis tanques y la mitad son impuestos' pues es una mentada de madre. $Y$ eso se nota en la cantidad de compartidas en el Facebook, cuando es un tema del gasolinazo es unánime: todos apoyan, todos quieren que lo quite y todos lo comparten (los videos) entonces creo que fue el gran tema de este trabajo como servidor público", expuso.

En Facebook, señala, la gente está ávida de que les expliquen de qué se trata el gasolinazo y cómo les impacta en su vida cotidiana.

Esto se traduce en los seis videos publicados por García Sepúlveda que se han hecho "virales" en redes sociales con más de un millón de reproducciones. Tanto así que se ganó el apodo del "diputado del gasolinazo".

"Se me empezó a calificar como el diputado del IEPS o el diputado del gasolinazo o el chavo del gasolinazo y le ha secado mucho jugo como yo sé que es ilegal tengo todas las armas para ir a México y eliminarlo y por eso ahorita está en mi agenda de propuestas la eliminación del gasolinazo", mencionó.

García Sepúlveda generó una serie de propuestas dentro de la agenda legislativa para tratar de introducir reformas fiscales a las leyes locales, pero como se trata de una norma federal, dijo, solo puede generarse una modificación desde la Cámara Alta. 
"Uno de los méritos es que me enfoqué en la materia fiscal, en la hacendaria. La gente ya me ubica por ahí y ya te vuelves hasta un líder de opinión del tema, y se te respeta por eso. Creo que de eso se trata: que los diputados o senadores, tengan sus especialidades y esas sean las que detonan desde los congresos", reflexionó.

Finalmente opinó que a un año de la protesta que se vivió el pasado 5 de enero del 2017, este tema sigue posicionado dentro de la esfera pública y continuará “dando de qué hablar", pues antes de la jornada electoral que se vivió el pasado 1 de julio el Gobierno mexicano comenzó a subsidiar el precio de la gasolina, presuntamente para no generar un costo político para el candidato presidencial priista, José Antonio Meade.

Sin embargo, al haber perdido en las urnas, el subsidio de 3 pesos podría concluir próximamente y regresar a los 24 pesos que actualmente cuesta el litro.

\section{Gilberto Lozano González Líder del Congreso Nacional Ciudadano}

Gilberto Lozano es un activista social radicado en Monterrey. Tiene una trayectoria de más de 16 años en el sector privado donde ha ocupado cargos como director ejecutivo de Administración, Finanzas y Recursos Humanos del grupo Alfa, también fue director de Recursos Humanos de la Cervecería Cuauhtémoc Moctezuma y posteriormente fue director corporativo de Recursos Humanos y Planeación del Grupo FEMSA.

También se desempeñó como presidente del Club de Futbol Rayados de Monterrey y como catedrático a nivel posgrado en el Tecnológico de Monterrey.

Lozano se define a sí mismo como una persona apartidista sin aspiraciones a un cargo en la función pública, sin embargo, después de haber pasado por el sector empresarial, deportivo y académico, admite que su vocación es el activismo y eso fue lo que lo impulsó a fundar el Congreso Nacional Ciudadano. 
Durante nueve años Gilberto Lozano ha impulsado, a través de su organización, diversas marchas, mítines y protestas pacíficas sobre temas que afectan a la comunidad.

El pasado 5 de enero del 2017 participó como uno de los principales organizadores de la marcha por el "gasolinazo": un acto en el que se concentró el rechazo de los ciudadanos al aumento gradual al precio de los combustibles.

En Nuevo León, dijo, este descontento por el gasolinazo se sumó a una serie de aumentos a los gravámenes y modificaciones en la recaudación fiscal que se aprobaron en el presupuesto estatal del 2017.

"Aquí hay un antecedente muy importante. Todo esto empezó por la aprobación del presupuesto 2017 del estado de Nuevo León, en él se estaba autorizando un aumento de la deuda de 5 mil 900 millones de pesos, se estaba autorizando un cambio en los impuestos prediales casi del 100 por ciento en algunos municipios de Nuevo León. Y se estaba autorizando por el Congreso del Estado un terrorismo basado en embargar los bienes de quien no pagara el predial.

"Ya en ese momento empezaba la decepción muy fuerte con (el gobernador del estado) Jaime Rodríguez, de que todas las promesas que él había hecho no se estaban cumpliendo. El señor no quería quitar todavía la tenencia... y a eso se suma el gasolinazo", dijo.

Por esta serie de imposiciones para los ciudadanos un grupo de aproximadamente 600 personas se reunieron el 26 de diciembre del 2016 afuera del Congreso de Nuevo León para manifestarse en contra de la aprobación del presupuesto, sin embargo, los legisladores y diputadas no dieron marcha atrás al acuerdo.

"La verdad es que el 5 de enero la agenda estaba cubierta: estaba el tema del gasolinazo, pero estaba todo lo demás y entonces hicimos algo inédito que las redes sociales nos ayudaron mucho, armamos 5 puntos desde donde iban a partir las diferentes marchas: el Tec de Monterrey, el parque La Pastora, la Universidad Autónoma de Nuevo León, el 
Mercado Juárez, el casco de San Pedro, y esos 5 (colectivos) nos íbamos a reunir a las 5 de la tarde en la Macroplaza”, explicó.

Previo a la marcha se realizó una convocatoria masiva en redes sociales que tuvo muy buena respuesta. Gilberto Lozano aprovechó para compartir videos descriptivos sobre el aumento al precio de los combustibles: sus causas y sus impactos en la economía de los mexicanos.

"El antecedente de ese 5 de enero fueron al menos 3 videos donde yo explicaba que el problema del costo de la gasolina en Nuevo León era el IEPS, el Impuesto Especial de Productos y Servicios, no era el costo de crudo no era un asunto de que la refinación se hacía en Estados Unidos, sino que simplemente en el costo le están poniendo 6 pesos a cada litro de impuestos y que por lo tanto estábamos 40 o 50 por ciento arriba de lo que vale la gasolina en Texas", comentó.

Estos videos, dijo, obtuvieron al menos un millón de reproducciones cada uno y consideró que muchas personas se interesaron en participar en la marcha a raíz de esta información que trascendió en las redes sociales.

"Yo te diría que el fenómeno social que se generó fue a través de las redes sociales y a pesar de los medios. ¿Por qué digo a pesar de los medios? Porque no nos daban cobertura, porque nos empezaron a calificar un poco de vándalos sin haberlo sido nunca, y creo que lo que le da fuerte impacto a este fenómeno social, es que es lo que le pega al bolsillo directamente de la gente", dijo.

Debido a que la convocatoria de la marcha estaba tomando mucha fuerza y para evitar cualquier acto violento durante la manifestación pacífica, el Congreso Nacional Ciudadano junto con líderes de otras organizaciones civiles acudió al Palacio de Gobierno para solicitar al Estado vigilancia y protección el día del evento.

“Tres días antes le anticipamos a Jaime Rodríguez Calderón --Tengo el oficio sellado y firmado-- de que le estábamos pidiendo que le proporcionara seguridad y protección a la integridad de todos los 
manifestantes que nos íbamos a poner en la Macroplaza el 5 de enero”, mencionó.

Con esta serie de antecedentes Gilberto Lozano comenzó a narrar los hechos sobre lo que sucedió el día del evento, cuando la violencia se desató.

"Empezamos a notar algo, que estaba empezando a llegar gente encapuchada y que la gente de Fuerza Civil se replegó en lugar de quitar. A la gente de Fuerza Civil se le ordenó por parte de un señor que afortunadamente ya no está en Nuevo León que se llama Cuauhtémoc Antúnez (ex secretario de seguridad pública del Estado) a él lo hago culpable de que Fuerza Civil, a pesar de que empezaron a llegar los reventadores, no hicieron nada; parecía que ellos los habían contratado.

"Al mismo tiempo que estaban quebrando los vitrales la gente de Fuerza Civil estaba atrás del palacio y tengo los videos (...) en donde demostraban claramente que los reventadores no eran gente de aquí, el acento que traían las personas, venían mariguanos, drogados, vimos que a algunos de ellos les pagaron en la parte de atrás del Palacio y concluimos que Jaime Rodríguez reventó el evento", dijo.

El 5 de enero quedó manchado por los desmanes y los daños a los vitrales del Palacio de Gobierno, y la protesta pacífica quedó opacada por estos hechos.

Posteriormente, Gilberto Lozano recibió una orden de aprehensión por presuntos cargos de desorden público, conspiración, agrupación delictuosa, daño en propiedades, lozas y daños a personas, pero el pasado 19 de julio del 2018 fue absuelto de las acusaciones con la sentencia de no ejercicio de la acción penal dictada por un juez.

“A los 8 días del evento yo ya tenía orden de aprehensión, nada más yo. $\mathrm{Y}$ los otros que fueron capturados infraganti yo diría que la mitad de ellos son totalmente inocentes y los metieron a la cárcel, totalmente inocentes. Gente que la agarraron para decir simplemente 'este cuate es uno de los que estaban quebrando los vidrios'; los verdaderos 
orquestadores de la quiebra de vidrios y de los desmanes ni siquiera fueron mencionados; fueron pagados", comentó.

Finalmente, el activista concluyó que el gasolinazo sigue siendo un tema importante y vivo dentro de la agenda pública, ya que sigue pegando al bolsillo de los ciudadanos y esto es lo que genera movimientos sociales.

"Yo considero el tema más importante de México el de la impunidad. El que aquí nadie paga por los delitos y eso genera un circulo de corrupción y la corrupción aumento de impuestos y entonces tienes un círculo perverso. Sin embargo, aquellas cosas que le pegan directito inmediato al bolsillo de los mexicanos son los que son más fácil que tomen fuerza como fenómeno social", opinó.

Finalmente señaló que el Gobierno es quien tiene la responsabilidad social por colocar estos temas dentro de la esfera pública y generar el debate con la ciudadanía para llegar a acuerdos que beneficien a todos, pero la corrupción es la principal traba para que esto suceda.

Por eso, dijo: "ellos han abdicado de su labor de desarrollo social y de responsabilidad social y no ha quedado de otra más que los ciudadanos nos hagamos responsables del destino de nuestras comunidades", concluyó.

\section{Periodistas}

\section{Medios de comunicación y sus representantes}

A continuación, presentamos los antecedentes de los medios de comunicación analizados en el presente estudio; su nacimiento, expansión y actual consolidación. Asimismo, se destacan algunos detalles sobre el alcance que tienen entre la sociedad mexicana y el manejo desde sus consejos administrativos y dueños.

Esta breve semblanza de los medios, antecede a las entrevistas que se realizaron a los titulares de las Jefaturas de Información, Directivos y Conductores, además de los periodistas que dieron cobertura a la protesta social conocida como Gasolinazo, que ocurrió el 5 de enero 
de 2017 en la explanada de los Héroes, frente al Palacio de Gobierno de Nuevo León, Monterrey, México.

\section{Aristeguinoticias.com}

Inició operaciones el 16 de abril de 2012, se define como un sitio de noticias e información dirigido por "un grupo de profesionales del periodismo y especialistas en internet y redes sociales".

En un inicio, el sitio se mantuvo con poco tráfico informativo y de usuarios durante sus primeros dos años de operación para luego comenzar con a mejorar su posición entre el 2014 y 2015; pero fue hasta el 2016 cuándo tomó el verdadero auge y fue consiguiendo la confianza de sus lectores, esto ocurrido poco después de la salida de la periodista Carmen Aristegui de MVS Radio en 2015.

Tras el sonado despido, la periodista y dueña de dicho portal, anunció regresaría con un nuevo noticiero, transmitido vía internet, a partir del 16 de enero de 2017, fue así como llegó "Aristegui En Vivo" a su transmisión en el portal aristeguinoticias.com, logrando así el éxito que se tiene en la actualidad.

El tráfico en este sitio de noticias mejoró considerablemente, incluso, el 9 de febrero de este año, publicaron una nota que señalaba que eran líderes en noticias digitales en México, respaldados en un estudio de Reuters Report, que se realizó mediante 70 mil encuestas en 36 países

El estudio de Reuters Institute for the Study of Journalism (RIS), en colaboración con la Universidad de Oxford. El estudio contempla 70 mil encuestas que analizaron la industria de las noticias en 36 países. En el reporte se habla sobre la confiabilidad de los portales de noticias, ante un ambiente de 'fake news' y la desconfianza sobre la información que se comparte en redes sociales.

En la sección dedicada a México, se establece que Aristegui Noticias "es la marca de noticias en línea más utilizada en nuestra encuesta (41\%)"; se coloca a este medio por arriba de marcas como El Universal, 
CNN, Yahoo, Tv Azteca, entre otras en el porcentaje de uso semanal, con 41 por ciento.

El portal cuenta con un diseño sencillo, con de dos colores; el rojo y el blanco. El menú de navegaciones inicia con las noticias más recientes y relevantes; cuenta con pestañas adjuntas sobre secciones de: entérate. México, economía, deportes, opinión, multimedia, libros, viajes, mundo, quiosco, especiales, y sus respectivas cuentas de Facebook, Twitter, Google y YouTube, en esta última se mantiene entrelazada con los programas que se transmiten en vivo dentro del portal y apoya con el orden de las fechas.

\section{Melva Frutos Ayala \\ Corresponsal de Aristegui Noticias}

Melva Frutos Ayala es periodista y cronista independiente; ha colaborado para distintos medios locales, nacionales e internacionales como POSTA, El Universal, Reporte Índigo, Agencia de Noticias EFE, entre otros. En 2014, recibió el premio estatal de periodismo de Nuevo León; es una mujer comprometida con su trabajo que investiga y escribe con total profesionalismo y veracidad.

Actualmente, es corresponsal en el estado de Nuevo León para el portal web Aristegui Noticias y durante enero de 2017 cubrió la serie de manifestaciones que se llevaron a cabo en la ciudad por motivo del 'Gasolinazo'. Particularmente, la que se realizó el día 5 de enero, saliendo de Colegio Civil rumbo a la explanada De Los Héroes, que fue convocada por los activistas Gilberto Lozano, del Consejo Nacional Ciudadano, y Pedro Alejo 'el Fufito', que dirige la organización Ciudadano Empoderado,

De acuerdo a Melva Frutos, las redes sociales fueron primordiales para la convocatoria a la protesta; principalmente Facebook porque son más las personas que "se enteran por Facebook que por otro medio". Debido a que este evento se proyectaba como algo importante para la ciudad, "sobretodo tomando en cuenta que Monterrey no es una población que acostumbre a salir a exigir y a protestar", la cobertura de los hechos se diseñó con anticipación. 
Previo a la convocatoria y al inicio de la concentración en Colegio Civil, punto de salida de la marcha hacia el Palacio de Gobierno, no había señales de que la manifestación fuera a tornarse violenta, sin embargo, a decir de la periodista, una vez que los contingentes comenzaron a avanzar, quedó claro que había posibilidades de que se saliera de control, por lo que tuvo que modificar el diseño de su cobertura periodística: "se sentía que se iba a salir de control porque estaba muy desorganizado", recuerda.

En México, los periodistas que trabajan por su cuenta o "FreeLancers", diseñan sus propias agendas en relación a los hechos más trascendentes para la región en la que laboran y eventualmente reciben solicitudes específicas de sus clientes, sin embargo, no cuentan con un respaldo legal o seguridad social, por lo que deben medir cuidadosamente los riesgos a los que se enfrentan.

Melva recuerda que el 5 de enero de 2017, durante la manifestación se pudo ver como los organizadores y participantes comenzaron a gritar, a pelear y a discutir entre ellos; cuando "se fue poniendo la cosa un poquito más violenta... entonces ya empiezas a prepararte para que se ponga peor". Ante esto, ella aplicó un plan de contingencia que ya tenía practicado gracias a una serie de talleres de protección del periodista que ha cursado.

Al preguntarle en que consiste el plan, lo describe de la siguiente forma "primero que nada, en buscar un lugar seguro para ti, si quieres seguir haciendo la cobertura... puedes seguir haciéndolo buscando un lugar que te resguarde físicamente, que proteja tu integridad física y ya de cierta manera colocas la cámara en una posición que puedas seguir grabando, pero que tu cuerpo esté protegido”.

Gracias al plan de protección que aplicó, Melva Frutos no sufrió ningún ataque ni agresión durante la cobertura; sin embargo, varios de sus compañeros de otros medios sí: "compañeros golpeados, otros con vidrios, lanzaron gases lacrimógenos los policías y les caían a los reporteros y a los fotógrafos." Incluso uno de ellos "se quedó sin un pedacito de oreja", debido a un petardo que le lanzaron. 
Sobre la violencia en la marcha, Melva describe que inició en la explanada De Los Héroes, cuando ya estaban en el escenario "empezaron a aventar cuetes, petardos o no sé qué onda al escenario. Ahí fue donde se armó la bronca". Menciona también que en la premura de los hechos hubo 'fake news' sobre los provocadores de la violencia: "empezó a trascender mucha información que no era cierta, como que los chicos que vandalizaron el Palacio de Gobierno eran los chicos los que andan todos de negro... (El Bloque Negro)".

Al respecto del Bloque Negro, que en el estado llevan el nombre de Nuevo León Antifascista, la periodista los describió como quienes "actúan en las protestas como apoyo, pero para proteger a los protestantes y aquí estos salieron embarrados, dijeron que habían sido ellos, entonces muchos nos fuimos con la finta de que habían sido los de El Bloque Negro, porque así lo hicieron creer." Sin embargo, Melva señala que posteriormente René, el de El Bloque Negro, aclaró y dijo que el grupo no realizó los destrozos e identificó a un grupo de jóvenes que se mezcló con ellos como autores de los hechos.

Molesta, la periodista destaca que ante los hechos de violencia a los organizadores "les valió madres, se lavaron las manos, se bajaron del escenario y salieron de ahí. Ellos nada más convocaron, no tuvieron un control de la situación", y lamentó profundamente este hecho debido a que "no es como que la gente se anime a salir a protestar, no es tan fácil que un regiomontano (salga)" y teme que frente a la situación que se vivió en la serie de manifestaciones por el gasolinazo la gente lo haga menos.

Al contrario de la actitud de los organizadores, Melva señaló el papel que ejercieron los policías durante la situación de violencia en el Palacio de Gobierno, mencionó que "los policías actuaron como debieron porque fue un despapaye. Se defendieron lo más que pudieron porque me acuerdo que trataban de contener a los muchachos sin golpearlos, al principio. Hasta que ya era demasiado y pues órale contra quien se les ponía en frente." 
Casi para concluir la entrevista Frutos Anaya comentó que este tipo de manifestaciones idealmente deberían tener un impacto "debería haber una decisión derivada (de estas) pero, desafortunadamente, ya vimos que no lo hubo. Hablando de manifestarse y de exigir lo que nosotros queremos o creemos que es lo correcto, pues se trata de manifestarnos más seguido o tomar otro tipo de acciones para que pueda haber una respuesta real a nuestra exigencia, porque luego pasa como esta vez que la gasolina sigue aumentando. Realmente, no hubo una respuesta ni un derivado positivo para nosotros."

Antes de finalizar la entrevista, Melva concluyó con una declaración muy importante para el ámbito periodístico y es que el periodista debe estar más preparado para hacer este tipo de coberturas "la preparación sí debe ser en todos los sentidos, también de protección para nosotros mismos y de protección y verificación de nuestra información" y "los medios nos deben garantizar los métodos y las herramientas para llevar una cobertura de buena calidad en la que no tengamos que arriesgar nuestra integridad física."

\section{Multimedios Televisión}

Multimedios Televisión, antes llamado Canal 12, inició sus transmisiones el 24 de febrero de 1968 como una cadena de televisión local fundada en Monterrey, Nuevo León, por Jesús Dionisio González.

Hasta agosto del año pasado Multimedios Televisión tenía presencia limitada en Monterrey y Linares, en Nuevo León; Torreón y Saltillo, Coahuila; Ciudad Juárez, Chihuahua; León, Guanajuato, y Ciudad Victoria, Tampico, Nuevo Laredo, Reynosa y Matamoros, en Tamaulipas.

Sin embargo, en una estrategia por convertirse en la cuarta cadena nacional más importante en México, en agosto del 2018 anunció la ampliación de su cobertura a la Ciudad de México y su Área Metropolitana, Chihuahua, Coahuila, Durango, Jalisco, Puebla y Tlaxcala. 
En este sentido la cobertura de la cadena televisiva pasó de 13 millones 142 mil 810 personas a un total de 45 millones 905 mil 401 personas en 18 diferentes ciudades en televisión abierta, adicional a la cobertura que tiene mediante televisión "de paga".

Multimedios también transmiten sus programas en los estados de Texas, Utah y California en Estados Unidos, así como en Costa Rica y Perú.

Su contenido se basa principalmente en programas de entretenimiento, deportes y noticias, como: Acábatelo, Destardes, Es Show, Las Noches del Fútbol, Vivalavi, Es Show el Música, Contadísimo, Vigiladísimo, Cambios, y el noticiero Telediario.

Actualmente Grupo Multimedios es dirigido por Francisco González Sánchez, presidente del consejo de administración de la empresa, Francisco González Albuerne, presidente Ejecutivo y Jesús Dionisio González Albuerne, Vicepresidente de la empresa.

\section{Mayte Villasana \\ Reportera de Multimedios}

Mayte Villasana, de 27 años de edad, es reportera de Multimedios Televisión. Se graduó como licenciada en Información en la Facultad de Ciencias de la Comunicación de la Universidad Autónoma de Nuevo León (UANL).

Desde hace siete años ha colaborado en diversos medios como Televisa Monterrey o la revista Ciencia de la UANL. Actualmente es reportera para televisión y radio del Grupo Multimedios y periódico de Milenio.

A lo largo de su carrera, dijo, ha tenido que cubrir manifestaciones de distinta índole en la zona metropolitana de Monterrey. Sin embargo, la protesta del 5 de enero del 2017 por el "gasolinazo" generó en ella una gran expectativa por la cantidad de gente que iba a acudir. 
El "gasolinazo" se entiende como la acción de aumento al precio del combustible de manera paulatina entre finales del 2016 y principios del 2017, lo cual ocasionó una molestia generalizada en todo el país que desató protestas en contra del Gobierno Federal.

"Era un ejercicio bastante importante, un ejercicio que todos queríamos cubrir porque ellos (los convocantes a la manifestación) ya tenían un estimado de las personas que iban a acudir a ese punto. Entonces, Nuevo León no se ha caracterizado por tener manifestaciones masivas, por lo regular eso se ve más al sur del país, pero nunca en el norte", recordó.

Explicó que parte de esta expectativa fue generada por el alcance que tuvo en redes sociales la convocatoria al evento, que se viralizó en Facebook principalmente.

Villasana identificó a cinco grupos organizadores de la manifestación, entre ellos pueblo bicicletero y grupos de transportistas, entre otros, que lanzaron la convocatoria en redes sociales.

"Las redes sociales tuvieron un papel importante para las personas que realmente deseaban buscar esta manifestación pacífica. Al principio yo creo que fue la manera en la que pudieron atraer personas, tal vez hacer el papel de convencimiento y la ciudadanía estaba harta. ¡Y claro! porque cada mes iba aumentando el precio (de la gasolina). Aparte de estos cinco grupos yo creo había más personas que se animaron a través de redes sociales a sumarse a esta causa, a esta marcha".

Aunado al hecho de que Monterrey no se caracteriza por ser sede de manifestaciones masivas, Mayte Villasana expresó que la convocatoria era explícitamente para realizar una protesta pacífica, de manera que los hechos violentos que se desarrollaron ese día los tomó por sorpresa a todos.

La indicación para la cobertura de ese día, dijo, fue hacer una nota de color, que se caracteriza por el tono alegre y descriptivo en la redacción, pero conforme fue avanzando la noche y la protesta se tornó violenta, 
la orden de sus jefes cambió a pasar enlaces para televisión en vivo y describir todo lo que sucedía.

"Nunca pensamos que iba a ser de esa manera (...) nadie pensó que se iba a tornar violento este asunto, he incluso la indicación era hacer una nota de color, que por primera vez la Explanada se iba a llenar de asistentes de manera pacífica, era lo que estábamos esperando desde las 5 pm ese día: una manifestación pacífica que iba a concentrar cinco grupos, los cuales iban a partir de destinos puntos del área metropolitana.

"Todo el tiempo estuvimos al aire. Había unas veces que era inevitable no ver los destrozos, y claro, como ciudadana te duele lo que está pasando, entonces era increíble ver la magnitud de los actos vandálicos que se estaban cometiendo. Te dolía tantos años en ese lugar, patrimonio del estado, del país y en tan solo en unos segundos están siendo destrozados (los vitrales del palacio de Gobierno)", mencionó.

Villasana detalló que alrededor de las 19:00, cuando ya todo el contingente estaba concentrado en la Explanada de los Héroes, comenzó la agresión.

En su opinión personal el grupo que causó los actos vandálicos lo hizo apropósito para "reventar" una manifestación que había sido pacifica hasta ese momento y tornarla en algo negativo.

"Llegó un grupo de unos chicos muy jóvenes. Yo calculo que había personas de entre 18 a 28 aproximadamente, la mayoría encapuchados, obviamente cubriéndose el rostro para evitar ser captados. Eso fue lo que llamó la atención ya que todos los ciudadanos estaban completamente identificados, algunos traían playeras, otros más traían pancartas; y ellos nos llamó la atención como de pronto llegaron, llegaron muy agresivos, rompieron filas, empezaron a romper la organización que ya estaba prevista y de inmediato se fueron hacia el frente del palacio, lo más cercano que pudieron estar. Bajaron a las personas que estaban hablando en ese momento en el templete, los empezaron a agredir y comenzó la agresión contra quien estuviera en frente de ahí. 
"Hicimos una reflexión la mayoría de personas que estuvimos cubriendo este evento, luego tuvimos junta ese mismo día sobre la cobertura con los jefes de información, con nuestros coordinadores; la mayoría de los compañeros concluyó que estaba meramente planeado, no tenemos las pruebas para decir quienes, pero suponemos que algo había detrás", señaló.

Un punto clave para respaldar esta afirmación anterior fue que muchos otros ciudadanos intentaron controlar la situación de riesgo y evitar los actos vandálicos, formando una valla humana al frente del Palacio de Gobierno.

"Hubo otros ciudadanos que por su propia cuenta empezaron a hacer vallas para tratar de tranquilizar a la gente, trataban de hablar con ellos de que terminaran con los actos vandálicos, de evitar romper los vitrales históricos (sic). Yo creo que con esa imagen me quedo: que un grupo de ciudadanos que en realidad iban de manera pacífica hicieron vallas para impedir que personas ajenas cometieran ese delito. Y después descubrimos de acuerdo a las investigaciones que hicieron las autoridades que ese grupo (de agresores) ni siquiera eran habitantes del estado de Nuevo León.

La respuesta de las autoridades, dijo, fue tardía, pero en ningún momento respondieron de forma violenta contra los ciudadanos, ya que solo trataban de proteger los vitrales históricos del Palacio de Gobierno.

"Los hechos comenzaron como por las 19:30 la autoridad yo creo que arribó una media hora más tarde, fue un grupo de antimotines, tal vez unos 20 o 30 elementos, pero nada se compara con el número de personas que estaban cometiendo los actos vandálicos, sí se tardaron al salir a la trifulca, recuerdo que hicieron una valla en las escalinatas del palacio de gobierno y evitaban únicamente que las persona ajenas ingresaran al palacio de gobierno, no recuerdo haber visto alguna agresión por parte de ellos, únicamente estaban formando una barrera contra las personas que querían entrar al palacio de gobierno. 
Para concluir se le preguntó a la reportera: ¿Recuerdas alguna otra manifestación masiva reciente (últimos 10 años) de esta magnitud en Nuevo León?, a lo que contestó:

"No, por eso es histórica, nunca se había visto el número de ciudadanos que se habían congregado para marchar por distintos puntos del área metropolitana y concentrarse allí (en la Explanada de los Héroes).

"Habíamos seguido mucho a los maestros que manifestaban contra la reforma educativa pero nunca igualaba el número de personas que se habían concentrado, ni el cierre de campaña de Jaime Rodríguez Calderón, ni Andrés Manuel López Obrador, ni la marcha gay ha llenado la Explanada de los Héroes como sucedió ese día”, expuso.

\section{TV Azteca Noreste}

TV Azteca Noreste es un canal de televisión que forma parte de Grupo Avalanz, un corporativo que integran empresas como Zignia Live, Súper Boletos, Universidad CNCI, El Horizonte y Expo Tampico, además de complejos de espectáculos como Arena Monterrey y Arena Ciudad de México.

El Presidente de Grupo Avalanz, Guillermo Salinas Pliego, es a su vez hermano del empresario Ricardo Salinas Pliego, dueño de Televisión Azteca S.A.B de C.V. (comercialmente conocida como TV Azteca) y de empresas como Banco Azteca y Grupo Elektra.

La familia Salinas Pliego ha sido ligada al Estado desde el año de 1990, cuando Carlos Salinas de Gortari, que en aquel entonces fungía como Presidente de México, anunció los planes para desincorporar a la televisora paraestatal Imevisión, que posteriormente fue subastada al sector privado para su explotación comercial.

El 8 de febrero de 1993, fue publicado en el Diario Oficial de la Federación la integración de la empresa paraestatal, Televisión Azteca, la cual reemplazaría a Imevisión. Finalmente, la paraestatal fue fundada para facilitar la entrada de ésta red de televisión a la subasta del paquete 
de medios. La privatización de los que hasta aquel entonces eran los canales del Estado fue posible después de un largo proceso de licitación pública en el que resultó elegido para llevar a cabo la compra el grupo Radio Televisora del Centro, encabezado por el empresario Ricardo Salinas Pliego, propietario de la cadena de venta de muebles y electrodomésticos Elektra.

La familia Salinas Pliego (en especial Ricardo Salinas Pliego), ha sido ligada en diversas ocasiones con el aspirante a la Presidencia de México Andrés Manuel López Obrador, con quien según diversos archivos periodísticos mantiene una gran relación.

Además, la Familia Salinas Pliego ha sido señalada por su supuesto parentesco con el ex Presidente Carlos Salinas de Gortari, hecho que siempre han desmentido.

\section{Leticia Benavides}

\section{Conductora TV Azteca Noreste}

Leticia Benavides (Lety) es una reconocida periodista con más de treinta años de trayectoria en los diversos medios de comunicación. Actualmente labora en Televisión Azteca Noreste y MVS Radio.

Es en la televisión donde la conductora cuenta con un espacio informativo desde hace dos años, tras la digitalización de la señal abierta en 7.2. Aunque entre sus labores no se encuentra propiamente el diseño de la cobertura, cuenta con el conocimiento de la agenda. Benavides cuenta que la empresa para la que trabaja fue convocada a la manifestación "En contra del Gasolinazo" a través de comunicados que llegaron por parte de diferentes Organizaciones de la sociedad civil; entre ellas recuerda el Congreso Nacional Ciudadano encabezado por Gilberto Lozano, así como Únete pueblo, que dirige Rocío Montalvo, y Ciudadano Empoderado donde está Pedro Alejo Rodríguez (Fufito), pero deja en claro que posiblemente participaron más colectivos.

Señaló que ella personalmente se enteró de la manifestación por medio de los comunicados y redes sociales como el resto de las personas: "Yo me enteré por los comunicados previo a, me enteré por medio de 
WhatsApp y por Facebook; principalmente por Facebook y WhatsApp que me enviaron".

Lety opina que las redes sociales juegan un papel importante en este tipo de manifestaciones: "Fue a través de las redes sociales como Facebook principalmente donde ellos convocaron a la gente".

TV Azteca como medio no pudo transmitir en vivo en televisión, puesto que aún no tenían un espacio informativo a la hora en que se estaba dando el acontecimiento: "Nosotros como TV Azteca no, porque no teníamos en ese momento un espacio informativo, no estábamos todavía con A+. A+ empezó hasta marzo del año pasado". Destaca que todos los medios de comunicación comúnmente se anticipan a diseñar cada una de las coberturas que se van a realizar, sobre todo cuando se da a conocer algún evento como lo fue la manifestación contra el Gasolinazo, TV Azteca no fue la excepción. La empresa designó a tres equipos de reportero y camarógrafo" para que estuvieran en la zona de la manifestación, sin embargo, cuando inician los saqueos se enviaron reporteros a las zonas donde estos ocurrían.

Reconoce que ni la empresa ni producción del noticiero logró planear algún tipo de protección o seguridad para los reporteros que estaban en la zona de la manifestación, ya que realmente nadie se imaginaba que los hechos se fueran a poner violentos porque desde un inicio a esta "marcha" se le consideraba como una "manifestación pacífica".

Al estar frente a los hechos violentos, y no haber planeado nada, el equipo de reporteros, fotógrafos y camarógrafos solo recibieron la indicación de cuidarse, pero de seguir atentos a lo que estaba pasando: "en ningún momento se les pidió que abandonaran la nota, a pesar de que hubo agresiones al equipo, a las unidades móviles, una casi la voltearon, la destruyeron, el equipo también resultó dañado por un grupo de personas en contra de la televisora".

En la opinión de Lety, los hechos violentos en esta manifestación, dejaron claro que hubo personas infiltradas ya que la molestia de los regiomontanos no era suficiente para causar esos disturbios: "Claro, definitivamente y traían consigna, y traían una orden para provocar la 
dispersión de los manifestantes, el sentir de las personas de Monterrey no era el suficiente como para actuar de este modo, eso fue planeado, fue orquestado para poder disuadir la manifestación", insiste.

El tiempo que se destinó en los noticieros de la empresa para el tema de la manifestación y los disturbios que sucedieron, fue casi la semana completa de notas; la cantidad de personas que asistieron hizo que fuera algo histórico.

La conductora cree que esa manifestación en contra del Gasolinazo, realmente era un "pretexto" para manifestarse contra el gobierno del Estado: "Yo creo que fue un pretexto para... ósea el pretexto de lo que estaba ocurriendo en otras partes del país, las manifestaciones que se estaban dando contra el gasolinazo fue un pretexto aquí en Nuevo León para manifestarse contra el gobierno del estado, yo no recuerdo aquí en Monterrey en mis treinta y tantos años que tengo en medios una manifestación de esa magnitud, nunca se había dado”.

Asimismo, criticó el actuar de las fuerzas de seguridad ante los hechos violentos; destaca que había muchos reporteros y manifestantes que se encontraban en la zona de los disturbios y estaban expuestos a la agresión. Insiste que pareciera que no estaban preparados para reaccionar ante una situación de esta naturaleza:

"El gobierno, comúnmente debería actuar rápido ante hechos violentos como los que surgieron en esa manifestación, sin embargo, en esta ocasión se vio lento, en palabras de Lety, reporteros que se encontraban en la zona declararon que hacía falta más seguridad, no había seguridad, no había orden, no actuaron oportunamente, por eso se dieron los hechos que se dieron".

$\mathrm{Al}$ igual que la mayoría de los periodistas que hablan sobre este tema, para Benavides, si existió una intención clara de sacar de orden lo que estaba programado como una manifestación pacífica, con la infiltración de personas que iban con la consigna de cometer actos vandálicos, como la destrucción de los vitrales en el Palacio de Gobierno. 
Sin embargo, reconoce que gran parte de las personas presentes que pedían cordura: "también hay que reconocer que había muchísima gente que estaba dentro de la manifestación o que estaba dirigiendo la manifestación que estaba llamando a la cordura, a la paz que era una manifestación pacífica y que no había que atender los actos de violencia que se estaban suscitando".

En cuanto al papel de los líderes sociales que convocaron a la manifestación, destaca que no supieron prever la cantidad de gente que asistiría, no tomaron el control de la situación y en días posteriores afirmaron que fueron infiltrados.

En TV Azteca, la mañana siguiente a los hechos la orden fue precisa: "decir las cosas tal como pasaron y tomando en cuenta la opinión de las personas que estuvieron presentes en los hechos. La indicación fue consignen los hechos, digan las cosas como pasaron, vamos a darle la voz a todos los que estuvieron ahí tanto a la ciudadanía porque se entrevistó a varia gente que fue a la manifestación”.

En su momento, el espacio informativo que conduce destacó que la manifestación de origen fue espontánea y de buena fe, incluso señalaron tener conocimiento de que en muchas empresas se les dio salida temprano a sus empleados para que fueran a manifestarse.

Para finalizar, Lety Benavides comparó la situación que vivimos en nuestro país con la de otros países donde la sociedad se manifiesta sin ningún tipo de temor contra las acciones de gobierno que considera injustas: "Sale todo el pueblo a manifestarse y se van, y se paran en frente del palacio nacional en Bolivia contra la decisión de Evo Morales de incrementar las tarifas del transporte público, al grado de que Evo Morales tuvo que doblar las manos y dar para atrás a la decisión, gracias a la manifestación y al enojo del pueblo y ahí el pueblo fue el que protesto y obligó a la autoridad máxima de Bolivia a echar para atrás la decisión”.

"Ese es el poder real del pueblo y es increíble que países tan pequeños que no tienen el desarrollo económico y social que pudiera tener 
México y que son mucho más pequeño sean mucho más poderosos que nuestro propio pueblo", concluye.

\section{Radio y Televisión de Nuevo León}

Es una televisora pública cuyos principales enfoques son lo cultural y la comunidad; es operada por el Gobierno del Estado de Nuevo León.

Inició sus transmisiones en mayo de 1982, con la intención de contar con una mejor comunicación entre los habitantes del estado y brindar contenidos distintos al resto de las señales comerciales.

RTV NL tuvo sus comienzos con su conocido Canal 28, en el cual inició sus primeras transmisiones, como repetidor de la Cadena Nacional Televisión Rural de México. La televisión Estatal, adscrita a la Secretaría General de Gobierno, del estado de Nuevo León, cristalizó el esfuerzo de iniciar transmisiones en vivo con una nueva imagen del canal 28 en marzo de 1984 esto bajo las siglas de XHMNLTV Canal 28, de Nuevo León al alcance de los neoloneses con el lema: "Esto es televisión, estamos comunicado".

Tras la regionalización del Canal 28, pudieron contar con instalaciones propias en mayo de 1985.

Luego en entre el 2000-2003, la señal de TV Nuevo León, logró ampliar su cobertura al entrar vía satélite con transmisiones propias a 30 municipios más del Estado de Nuevo León, por lo que ya tenían cubierto un total de 98\% en la población del Estado de Nuevo León.

TV Nuevo León, continuó creciendo hasta que, en marzo de 2006, logró concretar su proyecto de transmisión, convirtiéndose en el único medio de comunicación local que cubre con su transmisión, el 100\% de su territorio.

No obstante, fue en marzo del 2008 cuando se fusionaron los sistemas de Radio y Televisión del Estado de Nuevo León, los cuales, debido a la similitud de sus actividades y tecnología de ambos medios, garantizó una mejor calidad de transmisión en sus señales, fortaleciéndose la 
participación de los estados con muchos buenos contenidos en ambas programaciones.

En octubre de 2014 inicia sus pruebas para emitir su canal en señal digital en la madrugada apagando su transmisor análogo para el área metropolitana.

RTV Nuevo León produce 20 horas de noticieros a la semana, bajo el nombre RTV Noticias, repartiéndose 4 horas diarias de lunes a viernes; si bien genera la menor cantidad de tiempo de los canales de televisión en la localidad, RTV Noticias representa una opción alternativa a los espacios noticiosos de las emisoras privadas.

Cuenta con una página para enlace en vivo de los programas que maneja Tv Nuevo León. Dentro de esta se observan apartados como: gobierno, planeación, acciones, transparencia, servicios, información, buscador Google, así como también un listado de vídeos sobre programas pasados.

\section{Osvaldo Robles López \\ Director de Radio y Televisión de Nuevo León}

Para el director del sistema de radio y televisión pública de Nuevo León, los sucesos del 5 de enero de 2018, tuvieron implicaciones incluso en las determinaciones electorales que ocurrieron unos meses después.

Osvaldo Robles López trabajo para Grupo Reforma por más de 15 años y dirigió Radio y Televisión de Nuevo León, así como la dirección de Enlace y Prensa, ambas en el gobierno independiente de Jaime Heliodoro Rodríguez Calderón "El Bronco".

Destacó las pautas que tuvo que dar en su carrera profesional para poder avanzar, ya que la prensa había sido un oficio para él, y ahora vendría la incursión en los medios audiovisuales como la radio y la televisión. 
Durante el periodo de Gobierno de Rodríguez Calderón fue donde su carrera dio un giro de 180 grados, cuando se convirtió en director de Radio y Televisión de Nuevo León. El comunicador tomo el nombramiento como un nuevo reto en su vida y resaltó la importancia de generar un vínculo más adecuado entre los medios de comunicación y el Estado. Dada la naturaleza de su persona y de su posición como servidor público, a fin de cuentas, nunca ha querido pronunciarse acerca de un suceso controvertido en la sociedad de manera personal.

Robles López de una personalidad elocuente, de semblante serio y formal, sabe que los caminos del periodismo y de la vida común tienen que estar bien entrelazados siempre y de una manera responsable. "Es labor del medio destacar temas de utilidad social, temas que ayuden a los ciudadanos a tener una mejor calidad de vida, temas que impulsen políticas públicas que ayuden al desarrollo social y humano de las personas y obviamente también que vallan dentro de la agenda de la propia sociedad de las necesidades que tienen en un momento particular".

El también egresado de la Facultad de Ciencias de la Comunicación de la UANL entiende el entorno público y comprende que las redes sociales en plataformas digitales hoy en día son muy importantes.

El periodista mencionó que los sucesos noticiosos se ven de manera cuantitativa primero, y luego de manera cualitativa, lo que supone un análisis un poco engañoso de la jerarquía entre el saber y el tener que saber. Esto precisamente lo vivió de manera muy clara dentro de la controversia y caos social que se suscitó con el "Gasolinazo" pues el experimentado periodista cree que el acto generó mayor volumen critico a partir de la intervención maliciosa de algunos actores políticos.

“...fue un tema que nos reveló mucho de cómo está integrada nuestra nuestra sociedad nuestra clase política el tema en que se esfuerce manejo en los medios como nos dio también nos reveló mucho el comportamiento de las masas de la identidad de la gente de cómo reaccionaron prácticamente digamos un estallido que duró muy poco tiempo pero tuvo consecuencias graves más de 500 personas detenidos hubo incluso creo que un policía que perdió la vida en estas protestas, 
en estos levantamientos y asaltos que tuvieron en los en los comercios...", recuerda.

El ex reportero señala que el movimiento que derivó en protesta social tuvo su principal punto de ignición en las redes sociales, y muy pronto el término "Gasolinazo" se posición como trending topic, sin embargo, destaca que, entre los efectos negativos se encuentra el uso que hicieron también los grupos de choque de las mismas redes para emitir mensajes de violencia y convocar a saqueos a establecimientos comerciales.

También sugiere a la esfera pública como un fenómeno en que los diferentes grupos deben de actuar de manera constante y si es posible equitativa, pues todos se encuentran dentro de un mismo conflicto, políticos, medios y ciudadanía.

En su opinión, a poco más de un año de los hechos, el descontento de la gente permanece e incluso ha tenido implicaciones en los resultados electorales de la Elección 2018.

“...ha pesado a uno de los candidatos, al que se le relaciona con ese acontecimiento, ¿he?, pero creo que obviamente ya no es un tema que nos vaya a generar protestas en las calles. Yo creo que ya se diluyó en ese sentido que mucha de la gente qué protestó o que participó en esa manifestación, ciudadanos que defendían una causa legitima, después se manifestaron en contra de la violencia que derivo esas protestas no, entonces creo que ya es un tema ya asimilado, no digo que este bien, pero yo creo que difícilmente pudiera ser un tema que convocara a nuevas manifestaciones", concluye.

\section{Alberto Abrego Rodríguez \\ Coordinador del área de Servicios Informativos de RYTV NL}

El olfato periodístico forjado tras dos décadas de experiencia en el campo, permitió a Alberto Abrego Rodríguez, jefe de cámaras de TV Nuevo León "predecir" de alguna manera lo que sucedería la noche del 5 de enero de 2017, cuando vía redes sociales, los ciudadanos de Nuevo León fueron convocados a una protesta frente al Palacio de Gobierno, para protestar por el conocido "Gasolinazo". 
La plancha de la explanada de los Héroes fue el escenario donde se desató el caos, que el periodista de algún modo ya esperaba. 15 mil personas respondieron al llamado de una manifestación que terminó en violencia, actos de vandalismo y daño al patrimonio del Estado.

Pero Abrego ya lo "veía venir"; lo supo cuando, en el transcurso del día pudo saber, según información proporcionada por sus fuentes, como grupos manifestantes se conglomeraban por varias vías de la ciudad hacia el punto de encuentro.

Como responsable de la producción de los espacios noticiosos, tiene que tomar decisiones sumamente rápido y muchas veces en momentos críticos y álgidos. Aquella vez, él había decidido no mandar a un reportero pues se le veía nervioso y no tenía experiencia para el control de la situación en ese tipo de hechos, entonces fue cuando decidió tomar la batuta y salir junto con otro camarógrafo experimentado a la acción en las calles de Monterrey.

Durante la manifestación Abrego Rodríguez pudo percibir distintos grupos de manifestantes; desde aquellos ciudadanos que vestían formalmente, hasta los que decidieron en determinado momento taparse la cara:

"Se veía personas con la cara tapada o vestidos sumamente formales", contraste que le llamó la atención desde el primer momento, pues el segundo grupo cumplía con el perfil de aquellos que suelen iniciar a la violencia y exacerbar las pasiones de los manifestantes.

Como todo periodista de la vieja guardia, Alberto Abrego se puso en medio de la acción y se quedó grabando absolutamente todo lo que pudo de primera mano. Él sabe muy bien que la información más valiosa también es la más peligrosa y la más riesgosa de conseguir, pero los años de experiencia lo hacen cargar una dosis de adrenalina que pareciera natural en su semblante: "Yo me enfocaba en grabar los rostros de todos aquellos que estaban cometiendo actos de violencia o ilegales", repitió el jefe de cámaras. 
Dentro de la ilegalidad de los actos presenciados por Abrego ese 5 de enero de 2017, se encontraron varios hechos que estuvieron a punto de comprometer su integridad y la de sus compañeros, como el lanzamiento de petardos: "Cayeron explosivos muy cerca de mí, dije esto ya se descontrolo".

El periodista siempre ha estado consiente de los riesgos que se encuentran en esta profesión y ha podido salir bien librado en más de una ocasión.

A pesar de los múltiples hechos violentos que se suscitaron aquella tarde noche, el periodista piensa que la ola de violencia que fue claramente expuesta aquel día, tuvo lugar en unos cuantos que aprovecharon el frenesí y la frustración mal encausada de una multitud enardecida emocionalmente.

El jefe de información de Canal 28 concuerda con la postura de las autoridades estatales, pues estas no salieron a recibir a los manifestantes, ni dar algún tipo de explicación: "Creo que las autoridades hicieron las cosas bien de alguna manera, pues los manifestantes ya estaban en un punto incontrolable, quizá la intervención de los cuerpos de seguridad hubiera desatado un caos aun mayor".

Finalmente, señalo que, aunque el tema del "Gasolinazo" sigue presente sobre todo ahora con el clima electoral, la controversia ya no llegara a los mismos volúmenes mediáticos que tuvo y las manifestaciones o disturbios no se presentaran al menos en un futuro cercano; según el periodista, este tema del alza fiscal en el combustible fósil sencillamente se ha ido diluyendo en el imaginario de la opinión pública y en la agenda de la ciudadanía políticamente activa.

\section{Periódico Milenio}

El periódico Milenio fue fundado el 22 de noviembre de 1974 por Jesús Dionisio González, y forma parte del conglomerado de medios de comunicación mexicano, Grupo Multimedios. 
Originalmente comenzó a circular bajo el nombre El Diario de Monterrey, pero posteriormente en enero del 2000 amplío su cobertura a la Ciudad de México como periódico Milenio.

Actualmente Milenio es distribuido en toda la República Mexicana consta de 40 páginas en color. Sus secciones se dividen entre Nacional, local, finanzas, cultura, policíaco y espectáculos.

También cuenta con suplementos como el semanario M, Chic, Laberinto, La Afición, y El mundo de España en colaboración con Milenio, y Mercados de Financial Times.

De acuerdo con indicadores como la circulación, los suscriptores, las ventas y el tiraje se podría decir que Milenio se ha posicionado entre los periódicos más importantes en México compitiendo directamente con Reforma y El Universal, además de otros diarios como La Jornada, Excélsior y El Sol.

Milenio incursionó también en la televisión con un canal de noticias por señal abierta, satélite, y cable. Comenzó sus transmisiones en octubre del 2008 en Monterrey y después se extendió a Torreón, León, Nuevo Laredo, Ciudad Victoria, Tampico y Matamoros.

Luego de que Grupo Multimedios anunciara su expansión a otros estados de la república para alcanzar una cobertura nacional, se asignó también un canal a Milenio, pero esto aún se encuentra en etapa de instalación y prueba.

Francisco González Albuerne es el actual director General de Grupo Milenio, el cual, a su vez pertenece al conglomerado Grupo Multimedios, donde Francisco González Sánchez es el presidente del consejo de administración y Jesús Dionisio González Albuerne, es vicepresidente. 


\section{Daniela Mendoza \\ Jefa de Información}

Periodista de Monterrey que trabaja en el periódico de Milenio desde hace once años y actualmente se desempeña como jefa de información en este medio. Anteriormente trabajó también en el periódico de El Porvenir, y el semanario Hora Cero.

Durante la serie de manifestaciones y disturbios que se llevaron a cabo a finales de 2016 y principios de 2017, fue la encargada del diseño de la cobertura de estos eventos para el periódico Milenio. Para la manifestación, Daniela había diseñado la cobertura con anticipación; un día antes asignó dos reporteros: uno en el punto de encuentro y otro en el lugar de los hechos y dos fotógrafos, uno con cada reportero. Sin embargo, la cobertura fue modificada durante todo el día debido a cómo se fueron dando los sucesos del día.

Conforme la manifestación fue creciendo, la jefa de información del periódico Milenio envío otro reportero y otro fotógrafo y después tuvo que movilizar también a otras personas a los lugares de los disturbios: “empecé con 4 personas y terminé con 8".

Sin embargo, cuando se desataron los hechos violentos en la Explanada de los Héroes varios de los reporteros que realizaban cobertura ese día fueron agredidos y Daniela, como jefa de información tuvo que sacarlos de ahí. Tal como relató en la entrevista respecto a una de sus reporteras "no podía salir, la gente no la dejaba salir. Al final unos paramédicos la resguardaron en una ambulancia cercana y saqué del lugar a los demás, solo dejé a un fotógrafo y un reportero”.

Mendoza también relata que "se comentaba mucho de la posibilidad de algún disturbio respecto de un atropello de un menor de edad". "En redes sociales se generaba mucho odio contra multimedios así que había gente rondando, hubo problemas fuera del canal... y estuvimos encerrados hasta medianoche".

Así como se utilizaron las redes sociales para alentar a ese disturbio fuera de las instalaciones de Milenio y Multimedios, también fue a 
través de ellas donde se difundieron muchas fake news que extrañamente después se convertían en verdaderas. La periodista señala que "había por ejemplo en Twitter: 'disturbios en ciudad solidaridad por el gasolinazo' a las 3 o 4 de la tarde, mandamos gente, pero no había nada; pero después de la manifestación si los hubo."

Esta serie de hechos, sumando otros acontecimientos dieron la impresión de que se habían infiltrado grupos para reventar la manifestación. Tal como relata la periodista Daniela Mendoza: "gente que conozco desde hace años y otros periodistas que me lo manifestaron desde temprano (que había infiltrados) ... cuando iban caminando por la avenida Juárez empezó a haber gente que se empezó a incorporar al contingente, chavos con lentes, encapuchados, si se vieron y muchos me lo comenzaron a manifestar. Activistas: esto esta raro, compañeros de otros medios: está llegando gente muy extraña, gente que bajo toda de un camión y se incorporaron al contingente".

Además, posterior a los hechos de violencia y el daño causado a los vitrales del Palacio de Gobierno hubo muchos detenidos por las autoridades y Daniela señala que "se dio la oportunidad de tener información de que muchos no tenían domicilio en la ciudad, había gente del estado de México, gente del distrito federal, de Puebla y casi nadie era de la ciudad."

Finalmente, sobre la cobertura que dio a este acontecimiento grupo Milenio, Mendoza señala que fue de alrededor de dos semanas, a diario, "estamos hablando de ¿qué fue lo que pasó?, ¿porque la policía no actuó a tiempo?, ¿Cuántos detenidos hay?, la pérdida de los vitrales yo creo que se centró mucho en eso, las autoridades empezaron hablar de medidas de medidas de apoyo a la ciudadanía". Posteriormente se llegó a hablar del costo y el proceso de reparación de los vitrales y en la ocasión de un mohín en el Penal del Topo Chico se mencionó el tema porque uno de los reos fallecidos, había sido uno de los detenidos por los daños al Palacio. 


\section{César Cubero}

\section{Reportero Milenio}

César Cubero es reportero de Milenio Monterrey, y aunque su trayectoria en los medios de comunicación supera los 20 años, apenas este último lo ha hecho como reportero, en la calle. Su formación actoral lo hace una persona extrovertida y hábil para manejar sus emociones, lo cual queda en evidencia cuando habla de su labor.

El periodista narra los hechos que el experimentó ante las manifestaciones del Gasolinazo de una forma objetiva, pero cargada de los detalles producto de haberlo vivido, y el conocimiento del medio social y político en el estado que le da su experiencia.

César lo cataloga como un evento histórico en la ciudad de Monterrey, ya que los manifestantes creían que realmente estaban haciendo algo bien como ciudadanos: "era una manifestación social realmente auténtica, eran ciudadanos que querían expresar su inconformidad de manera pacífica".

Durante la plática deja en claro que la manifestación por el Gasolinazo espontánea, sino el producto de una amplia convocatoria a través de distintas vías, entre ellas las redes sociales.

'Yo supe de ese evento por lo que ponía 'Fufito' en sus redes sociales, lo que ponía (Gilberto) Lozano en sus redes sociales, por la invitación que se estaba siendo" agregó.

Por otro lado, aseguró que fue Pedro Alejo Rodríguez "Fufito", Gilberto Lozano del Congreso Nacional Ciudadano y otras tres asociaciones que no son del todo mediáticos quienes estuvieron convocando.

Cubero confesó no ser una persona que esté al tanto de las redes sociales, sin embargo, mencionó que fue mediante estas que se enteró del evento por lo que está convencido que todos los medios le dieron la cobertura que se merecía debido al impacto que estaba teniendo en las redes. 
"La mayoría en cualquier parte del proceso el Gasolinazo le afectaba, a todos nos afectó, ya sea por la gasolina directamente por cómo subieron precios, entonces esa parte del seguimiento obviamente estuvo en todas partes. Yo no pudiera saber sobre sobre las redes sociales como se manejó, pero en lo que es el evento obviamente todos los medios allí estuvieron, era la primera manifestación social que existiera aquí en el Estado, entonces obviamente estaba la importancia de todos los medios sobre esa situación".

César admite que no había señales de que se fueran a presentar acciones violentas, y no fue sino hasta el momento de la cobertura, que lo presenció con sus propios ojos cuando entendió que la protesta estaba tomando otro cariz.

“...ahí tú te das cuenta que algo está empezando a oler feo, tu ahí empiezas a ver como empieza a haber un desorden, pleitecitos por querer pasar a la tribuna y sin ser parte de los que van a hablar, como llega un grupo a querer reventar por atrás, una situación para meter a alguien, a mí me tocó ver personalmente ver a un grupo que se dijeron que se equivocaron, todo lo que estaba pasando, se veía que los grupos que venían llegando no era sociedad civil, eran grupos sociales de otro tipo y el ambiente se empezó a enrarecer, empezaron a haber situaciones extrañas y pues tú estás ahí escuchando lo que están diciendo los oradores pero empiezas a ver abajo como se empiezan a mover cosas extrañas".

Por otro lado, compartió una de las medidas que implementaron para estar al tanto de la seguridad del equipo que estaba encargado de la cobertura y que estaba cerca de la situación, añadió que todos estuvieron en una comunicación constante, luego de que comenzaran los compañeros de otros medios a salir heridos, comenzó la comunicación vía WhatsApp a través de chat interno.

“¿Dónde están? ¿Cómo están? y luego hasta que se da la situación de que voltean los carros en la calle o con el vandalismo, ahí es donde a todos nos suben a palacio y nos resguardan porque ya estaba fuerte la 
situación, yo en su momento hasta dije que estaba mal porque nos estaban resguardando a donde estaban tirando, por lo que había esa tensión por parte de los jefes, ya que sabes que hay algo, sabes que ya hay lesionados de compañeros de otros medios y entonces lo primero es ¿cómo están los de nosotros? y tratar de empezar de agruparlos, me tocó estar empezando a hacer equipo con los de Multimedios y pues te vas haciendo bultito, terminar por meterse al palacio y ahí la policía nos resguarda porque se cambió la protesta".

La cobertura del periodista de Milenio se realizaba desde el punto exacto donde comenzaron las agresiones, abajo del improvisado templete; entre los asistentes y las fuerzas del orden que cubrían la entrada al Palacio de Gobierno.

Explica que se sucedieron dos tipos de agresiones durante el evento; la primera hacia el edificio sede del Ejecutivo Estatal, pero la otra, de un modo que parecía planeado, se encaminaron casi inmediatamente hacia los integrantes de los medios de comunicación, especialmente de las televisoras Multimedios y Televisa.

“... ya estando ahí tú ya sabías de que ya estaba dirigido para los medios de comunicación en especial para Multimedios, para Televisa, para las televisoras, la violencia de los petardos, en los vitrales y toda esa parte de la violencia hacia el Estado o hacia la autoridad fue una, pero luego a la violencia directa contra los medios, eso sí estuvo muy marcado que eran dos tipos de cosas distintas, se acabó una y empezó la otra.

¡A nosotros nadie nos dio protección por así decirlo, mientras estaban los petardos y las quebradas vitales ahí estaban todos los reporteros, los camarógrafos, para mí son unos héroes ya que están en medio de los chingadazos, camarógrafos y fotógrafos están en medio de todo! Yo si estaba en palacio y luego me fui hacia donde estaban volteando los carros y ahí un conocido me sacó y me metió al cerco policiaco, entonces si había algo dirigido, yo estoy muy seguro de que había algo dirigido ya contra los medios en esa segunda parte de la violencia y si los jefes ahí estuvieron con atención todo el tiempo y con indicaciones de ¿qué hacer?, por donde venirse, etc.”, recuerda. 
En la óptica del periodista, la intervención del Gobierno del Estado dejó mucho que desear, pues fue muy evidente la falta de presencia de elementos de seguridad en un evento masivo tan grande. Incluso señala que la autoridad falló al cien por ciento, ya sea por falta de capacidad o por omisión.

Explicó que los asistentes a las manifestaciones, aquellos que fueron de modo voluntario estaban muy molestos por los hechos de violencia, y en muchas ocasiones intentaron calmar los actos vandálicos, o bien señalar a las autoridades quienes eran los grupos de choque, pero nunca fueron atendidos. Incluso algunos realizaron detenciones ciudadanas, pero los policías no retenían a estas personas y las dejaban ir.

Además, César asegura que dentro de esa protesta de manifestación se veían claramente que había grupos que estaban infiltrados en esa manifestación, así como también había otros para convertir eso en algo pacífico con el dichoso grito de "todos sentados" para poder descubrir quiénes eran las personas con mala intención.

“...es una realidad que cómo se actuó ese día tuvo un efecto, ya la gente no se volvió a reunir porque la sangre da mucho miedo, el ruido de las explosiones da mucho miedo, el caos de la gente al oír a conocidos que están gritando, ver de gente que está así lesionada, todo eso es un estrés muy fuerte y entonces mejor las personas siguen manifestando por las redes sociales y pues se ha perdido el poder de desde eso que se logró en esa ocasión.

...sin embargo, creo que fue algo muy auténtico, si había sus conflictos entre la gente que estaba en la tribuna, los egos naturales de gente que cree que puede, no cualquiera te convoca a tantos miles de personas, pero obviamente no fue por ellos, realmente el motivo era que hacía que las personas fuera pero yo creo que lo que queda es eso es que fue algo que la sociedad respondió a algo que se le hizo, algo que se le dañó, los medios respondimos, la autoridad falló, la manifestación estuvo infiltrada y a final de cuentas aquello se volvió un desorden, un desorden que pues ya recientemente nos costó la vida de una persona porque una de las personas detenidas por estar dañando los vitrales fue 
uno de los reos que murió posteriormente en uno de los problemas de violencia que tenemos aquí los penales del Estado, entonces indirectamente sí cobró vidas ese evento de ahí porque este muchacho de la porra de los rayados Gerardo Delgado Pérez y creo que la mayor factura es el hecho de ya no querer que la gente normal quiera volver a salir a la calle y bueno... al final de cuentas fue algo no muy agradable de cubrir porque te das cuenta de muchas cosas a tal grado de pensar en de que se trata esto".

\section{ABC Noticias}

La transmisión de la emisora XENV 1340 AM en 1957 dio inicio a Grupo Radio Alegría contando actualmente con 12 emisoras. En 1985 nace Periódico ABC (hoy ABC noticias), como una alternativa de información.

En 2004, surge ABC impresos, la planta de producción de impresos, la cual ofrece soluciones de impresión offset, digital y gran formato, esto surgió a raíz de festivales musicales en 2014. A pesar de que este medio surgió como apoyo y mejora, dio un gran giro y logró mantenerse hasta la actualidad.

Cabe recalcar que en el periódico ABC es uno de los preferidos por los ciudadanos para el envío de información instantánea, así como también videos de denuncias, este resalta por sus transmisiones en vivo mediante su página oficial de Facebook.

Esta página se mantiene activa la mayoría del tiempo y suele tener contacto directo, casi inmediato con sus seguidores, situación que no es muy vista en otras páginas de información.

\section{Erick Muñiz \\ Editor en Jefe}

Erik Muñiz es periodista y escritor desde hace más de 25 años. Editor en jefe del Periódico ABC, y entre sus obligaciones se encuentra la coordinación del equipo de editores, pero de manera muy importante el análisis de la información que se maneja en la multiplataforma con 
la que cuenta este medio de comunicación, que se compone de sitio de internet, radio y periódico.

Tiene una doble formación profesional como egresado de la Facultad de la Ciencias de la Comunicación, pero también con estudios en Filosofía y Letras por la Universidad Autónoma de Nuevo León; ha incursionado en la literatura con su libro "Amores Bohemios", publicado en 2017.

En torno a la manifestación ciudadana en rechazo al incremento de la tarifa de la gasolina, que se vivió en Nuevo León el 5 de enero de 2017, el periodista comenta que la primera noticia de que se llevaría a cabo este evento la tuvo por redes sociales y posteriormente mediante una cadena de WhatsApp, en la que se convocaba a los ciudadanos inconformes a asistir a la explanada de los Héroes, frente al Palacio de Gobierno de esta entidad.

"Tenemos grupos en redes sociales donde nos contamos todas esas cosas, entonces así llegó todo, fue todo muy rápido, por lo general todas esas protestas se mueven rápido y circulan rápido”, explica.

Destaca que, en la organización del evento se llegó a percibir la participación de organizaciones de la sociedad civil, pero también de partidos políticos y ciudadanos que acudieron por cuenta propia.

Para Muñiz las redes sociales tuvieron el mismo papel que han tenido en los últimos años en la sociedad, "funciona como un reguero de pólvora", que corre por todos lados con rapidez y en el que se aprovecha el enojo ciudadano por las acciones de gobierno, como un detonante para la manifestación.

En cuanto al papel que la información falsa jugó dentro de los hechos, el Editor en Jefe del Periódico ABC señala que este tipo de eventos, son campo fértil para los rumores, que se comenzaron a generar mucho antes de que se llevara a cabo la concentración y posteriormente la marcha: "pero como en todo, en ese tipo de manifestaciones siempre hay, ah que golpearon a uno, pero no han golpeado a nadie, ah que golpearon a otro, ah que unos tienen armas, a lo mejor si tienen armas 
pero jamás se comprobó, porque digo, es comprensible, yo puedo llevar una pistola, la saco y tú la ves, la vuelvo a guardar y ya me voy, si había un arma pero no tienes como comprobarlo si no me tomaste una foto o un video, entonces si humo muchas cosas de ese tipo", explica.

Ante los hechos, Erik destaca que el diseño de la cobertura fue realizado con anticipación, pues en el periódico $\mathrm{ABC}$ utilizan mucho el recurso de Facebook Live para estar en contacto con sus lectores, la mayoría de los cuales llegan a su sitio por medio de las redes sociales.

Este medio de comunicación utiliza la herramienta de esta red social para hacer continuos enlaces a la usanza de la televisión, con la ventaja de que se necesita nada más a una persona con un teléfono, en vez de dos personas, con un equipo de cámara profesional.

En base a su experiencia en el campo, Muñiz determinó asignar a tres reporteros, bajo el siguiente esquema:

"Siempre que hay protestas y como sabíamos que iba a ser grande, ponemos una persona donde va a iniciar, una persona donde va a terminar, desde antes y otra persona en medio y aparte alrededor, esos son reporteros y alrededor son fotógrafos, hicimos toda esa estructura, porque pues yo dije, la foto buena va a hacer desde arriba de la Macroplaza porque desde ahí puedes ver cuánta gente hay, yo pensando que iba a estar bien, que no iba a ser tan violenta, que la nota iba a ser en número de asistentes, entonces ya teníamos eso hay más o menos planeado.

“... conseguimos un dron, en ese entonces todavía no teníamos dron, entonces también lo llevamos; ya estaba más o menos diseñado. Cuando se hace el relajo, la violencia y se comienzan a romper los vitrales, cuando pasa todo eso entonces ya cambia en el sentido de que la nota ya era la violencia pero sí teníamos a la gente ubicada en un lugar donde pudiera saber todo, y ahí es importante tener ubicada a la gente bien, cerca pero no tanto como para que resulten lesionados como le pasó a algunos compañeros, hay que estar a una distancia prudente porque si no como periodista a mí no me sirve que yo te 
mando a que cubras algo y luego me resulte lesionado porque estabas muy cerca", explica.

En total, se asignaron cinco personas a la cobertura; tres reporteros y dos fotógrafos del Periódico ABC, pero también fueron apoyados por dos personas más que se encargaron del manejo del dron. Esto además de los editores web que se encontraban dentro de las instalaciones del periódico, recibiendo la información, pero también monitoreando otros medios de comunicación.

Durante los hechos la situación fue complicada para todos los medios de comunicación, principalmente para su cobertura por lo que todos tuvieron que agregar diferentes estrategias para poder manejar la situación. En el caso de ABC, Muñiz dijo que ellos si acaso solo tuvieron que ajustar lo de los enlaces, en Facebook Live, ya que cuando hay demasiada concentración de gente se satura la señal, por lo que se tiene que alejar y moverlos por turnos, sin embargo, cuando comenzó la violencia, la comunicación con sus reporteros se perdió por completo,

Reconoce que no era posible prever la violencia que se iba a desatar, por lo cual la mayoría de los medios no consideró la protección preventiva de sus colaboradores y cuando las cosas se salieron de control, otro factor que jugo en contra fue la perdida de comunicación

"Si acaso son cosas así pues mandamos a los hombres, a los más grandes porque hay que proteger a las chicas, con perdón de las feministas pero bueno yo protejo a las chicas, aunque a veces como quiera ellas quieran ir y me da mucho gusto cuando hacen eso, que se quieran aventar, tengo una fotógrafa chiquita, es así, bien aventada y digo que bueno, solo siempre con precaución, ya cuando ellas me dicen que quieren ir pues bueno ya las dejo, solo de medir los riesgos y si quieren ir, yo por mi encantado y con pensamiento positivo", agregó.

Contrario a su costumbre de emitir opiniones en torno a la información que se genera, el periodista señala que hay muchos elementos para pensar que personas externas se infiltraron en la protesta: "los organizadores lo comentaron, también lo vimos en los videos, a los que 
se enmascararon, esa era una protesta que no iba a ser violenta, ese fue el espíritu y desde que vemos a los chavos que se tapan en rostro y ya traían la idea, a veces había ciertas especulaciones, que eran de cierto partido, es que eran del mismo gobierno, que eso también es muy maquiavélico pero si tú quieres, si tú eres la gobernadora y quieres mandar simpatías con tu gente, gente que de verdad ya no te quiere, lo mejor que te puede pasar es que seas víctima de algo, entonces tu misma contratas a alguien, a un tirador que sea muy buen tirador y que te tire un balazo y que nada más te lastime y te vas a rodear de una gran opinión pública, entonces así es, suena muy maquiavélico pero así es, y acá es muy fácil decir, bueno contrato a alguien que haga daños en el palacio y nosotros decimos pues nos están atacando.

“... y aparte hubo fotos y videos de policías que detenían a la gente, las subían, se las llevaban a unas cuadras de ahí y las soltaba y ahora déjame decirte otra cosa, también tú lo vez y dices ahí hay algún arreglo, pero ahora te voy a decir una lógica que hay en eso porque ya en plática con policías mencionaban que eran pocas patrullas, entonces si yo voy y hay veinte tipos haciendo desastre y agarro a cinco, de aquí a que me los llevo, los bajo, hago todo el proceso y en lo que regreso y van a faltar los demás por lo que mejor agarraban a cierta cantidad, los alejaban, regresaban agarraban a otros pocos y así sucesivamente y con esto ya le van a pensar para regresar, ahora cual es la verdad, eso sino lo sé pero es la explicación que dan", revela.

En cuanto a la labor de los cuerpos de seguridad, aseguró que, en este tipo de circunstancias, los policías tienen órdenes de no atacar, y puso como ejemplo aquel video que se viralizó en las redes sociales.

El video muestra a un grupo de jóvenes intentando agredir a los elementos de policía, mientras otro sector de los manifestantes decide sentarse en el piso en señal de paz, para evitar que fuera ascendiendo la violencia entre los grupos de choque. De ese modo quedó en evidencia quienes se estaban protestando pacíficamente y quienes estaban agrediendo.

Tras la noche del 5 de enero de 2017, los hechos tuvieron un seguimiento por parte del periódico $\mathrm{ABC}$ por tres o cuatro días 
consecutivos, debido al impacto que estos hechos marcaron para la sociedad regiomontana. Explica que anteriormente se habían visto manifestaciones, activas, como las de los maestros en contra de la Reforma Educativa o las marchas por la Paz, pero ninguna que terminara con hechos violentos a este nivel.

En relación al papel que jugó el Gobierno ante estas manifestaciones, el periodista señala que hicieron lo que estaba dentro del ámbito de su competencia; involucrándose solamente en la contención de la violencia y la detención de quienes realizaron actos vandálicos.

Explica que realmente el Estado no tenía otra opción, pues no podía reprimir los hechos, pero tampoco alentarlos, y agregó:

"Hubo estados en los que sí, porque el gobernador no era del PRI, aquí pues se mantuvieron al margen a menos que hayan tenido algo que ver con estas provocaciones, pero pues eso no lo sabemos".

Finalmente, Erik Muñiz señala que las redes sociales actuaron como convocantes, pero no como detonantes de la violencia, pues la gente acudió a manifestarse pacíficamente en torno a un tema que les lastimaba en su economía personal.

"Veo las redes sociales no como las que inciden a la violencia sino como las que ayudan con la convocatoria, es decir, sin redes sociales quizá no hubiera ido tanta gente, estas ayudaron a que hubiera demasiadas personas.

“...la violencia surgió por los grupos, descontrol, el enojo de la gente y esto tiene que ver con las información, que se dé, el para que te están convocando, en sí el que surja la violencia no tiene que ver con redes, ni con los medios es la esencia misma del grupo lo que lo desarrolle y ya depende de la misma gente y ya no tiene que ver con otros factores externos", concluye. 


\section{Hallazgos sobre el papel de las redes sociales}

Desde la mirada tanto de periodistas que cubrieron los hechos, como de Jefes de Información de diversos medios de comunicación local, que diseñaron la cobertura, coinciden en señalar que el papel de las redes sociales el 5 de enero del 2018 fue fundamental como convocantes a la manifestación.

Algunos exponen que las convocatorias se realizaron de modo simultáneo a nivel nacional, y al parecer no coordinado por parte de ninguna de las distintas organizaciones de la sociedad civil; este fue un fenómeno coincidente en varios estados de la república mexicana debido a que se esperaban varias "movilizaciones espejo".

Las mismas fuentes coinciden en señalar que se había generado gran expectativa en la cobertura porque este tipo de manifestaciones políticas no suelen darse en la ciudad de Monterrey y su área Metropolitana.

Los Jefes de Información, Erik Muñiz de ABC, Alberto Abrego de Canal 28 y Daniela Mendoza de Milenio, coinciden en señalar que la convocatoria se recibió principalmente de redes sociales y que no queda claro si había o no un frente unificado que convocara a la protesta.

Sobre este mismo tema, los reporteros que se encargaron de cubrir la nota, exponen que el objetivo de la manifestación era el rechazo de la ciudadanía al incremento de la tarifa de la gasolina; el periodista Erick Muñiz (medio al que pertenece)(2018) comenta que la primera noticia de que se llevaría a cabo este evento la tuvo por redes sociales y posteriormente mediante una cadena de WhatsApp, en la que se convocaba a los ciudadanos inconformes a asistir a la explanada de los Héroes, frente al Palacio de Gobierno de esta entidad.

En la óptica de los reporteros, las redes sociales fueron fundamentales no solo para convocar la cobertura de los medios de comunicación, sino también para que el ciudadano en general acudiera; de acuerdo a Melva Frutos (Aristegui Noticias), las redes sociales fueron 
primordiales para la convocatoria a la protesta; principalmente Facebook porque son más las personas que se enteran por Facebook que por otro medio. Debido a que este evento se proyectaba como algo importante para la ciudad, sobretodo tomando en cuenta que Monterrey no es una población que acostumbre a salir a exigir y a protestar, la cobertura de los hechos se diseñó con anticipación.

Mayte Villasana, reportera de Multimedios, dice: "Las redes sociales tuvieron un papel importante para las personas que realmente deseaban buscar esta manifestación pacífica. Al principio yo creo que fue la manera en la que pudieron atraer personas, tal vez hacer el papel de convencimiento y la ciudadanía estaba harta. ¡Y claro! porque cada mes iba aumentando el precio (de la gasolina). Aparte de estos cinco grupos yo creo había más personas que se animaron a través de redes sociales a sumarse a esta causa, a esta marcha" (2018).

Incluso aquellos reporteros que señalan no acceder frecuentemente a las redes sociales tuvieron el primer conocimiento del evento, gracias a este medio de interacción, así lo destaca César Cubero, del periódico Milenio, quien también identifica a Pedro Alejo Rodríguez "Fufito" y a Gilberto Lozano como parte de los convocantes a la manifestación.

Este mismo reportero asegura que fue Pedro Alejo Rodríguez "Fufito", Gilberto Lozano del Congreso Nacional Ciudadano y otras tres asociaciones que no son del todo mediáticos quienes estuvieron convocando. "Yo supe de ese evento por lo que ponía "Fufito" en sus redes sociales, lo que ponía (Gilberto) Lozano en sus redes sociales, y por la invitación que se estaba haciendo".

\section{Infiltración}

Existe coincidencia entre los entrevistados acerca del tema de violencia, entre los puntos más relevantes son: 1) No se esperaba y 2) Fue orquestada.

Melva Salas, describe que inició a cubrir la nota en la explanada de los héroes, cuando los oradores ya estaban en el escenario, y empezaron a aventar cuetes, petardos o no sé qué onda al escenario. Señala que la 
primera información que circuló es que quienes iniciaron la violencia eran integrantes del llamado "Bloque Negro de Grupo Nuevo León Antifacista", pero que durante el trascurso de los hechos se comprobó que no formaban parte de los actos vandálicos.

Al respecto, las apreciaciones de Mayte Villasana, reportera de Multimedios señala: "Hicimos una reflexión la mayoría de personas que estuvimos cubriendo este evento, luego tuvimos junta ese mismo día sobre la cobertura con los jefes de información, con nuestros coordinadores; la mayoría de los compañeros concluyó que estaba meramente planeado, no tenemos las pruebas para decir quienes, pero suponemos que algo había detrás", señaló. Un punto clave para respaldar esta afirmación anterior fue que muchos ciudadanos intentaron controlar la situación de riesgo y evitar los actos vandálicos, formando una valla humana al frente del Palacio de Gobierno".

Por su parte, el reportero de Milenio, César Cubero asegura que dentro de esa protesta de manifestación se veían claramente que había grupos que estaban infiltrados en esa manifestación, así como también había otros para convertir eso en algo pacífico con el dichoso grito de "todos sentados" para poder descubrir quiénes eran las personas con mala intención.

A pesar de tener un puesto de toma de decisiones, Alberto Abrego, coordinador de servicios informativos de Canal 28, se encontraba en la zona de cobertura, supervisando la trasmisión en vivo, por lo que su óptica de los hechos es múltiple; la experiencia de los años en el periodismo y su testimonio personal.

Abrego firma que, en la protesta, se veía personas con la cara tapada o vestidos sumamente formales, contraste que le llamó la atención desde el primer momento, pues el segundo grupo cumplía con el perfil de aquellos que suelen iniciar a la violencia y exacerbar las pasiones de los manifestantes

Los Jefes de Información, Daniela Mendoza, de Milenio y Erik Muñiz de ABC coinciden en señalar que: "gente que conozco desde hace años y otros periodistas que me lo manifestaron desde temprano (que había 
infiltrados) ...cuando iban caminando por la avenida Juárez empezó a haber gente que se empezó a incorporar al contingente, chavos con lentes, encapuchados, si se vieron, y muchos me lo comenzaron a manifestar. Activistas: esto esta raro, compañeros de otros medios: está llegando gente muy extraña, gente que bajo toda de un camión y se incorporaron al contingente" (Daniela Mendoza, 2018)

Contrario a su costumbre de emitir opiniones en torno a la información que se genera, Erik Muñiz (2018) señala que hay muchos elementos para pensar que personas externas se infiltraron en la protesta: “...los organizadores lo comentaron, también lo vimos en los videos, a los que se enmascararon, esa era una protesta que no iba a ser violenta, ese fue el espíritu y desde que vemos a los chavos que se tapan en rostro y ya traían la idea, a veces había ciertas especulaciones, que eran de cierto partido, es que eran del mismo gobierno, que eso también es muy maquiavélico pero si tú quieres, si tú eres la gobernadora y quieres mandar simpatías con tu gente, gente que de verdad ya no te quiere, lo mejor que te puede pasar es que seas víctima de algo, entonces tu misma contratas a alguien, a un tirador que sea muy buen tirador y que te tire un balazo y que nada más te lastime y te vas a rodear de una gran opinión pública, entonces así es, suena muy maquiavélico pero así es, y acá es muy fácil decir, bueno contrato a alguien que haga daños en el palacio y nosotros decimos pues nos están atacando.

\section{Sobre la difusión de información falsa}

Cabe destacar que éste fenómeno de la información falsa solo fue percibida por parte de los Jefes de Información: Daniela Mendoza y Erik Muñiz, esto puede deberse en parte a que por su posición estratégica dentro de los medios y su experiencia periodística estén más conectados que los reporteros, y que parte de su labor diaria sea el monitoreo de redes sociales.

En cuanto al papel que la información falsa jugó dentro de los hechos, el director general del periódico $\mathrm{ABC}$, señala que este tipo de eventos, son campo fértil para los rumores, que se comenzaron a generar mucho antes de que se llevara a cabo la concentración y posteriormente la marcha: "pero como en todo, en ese tipo de manifestaciones 
siempre hay, ah que golpearon a uno, pero no han golpeado a nadie, ah que golpearon a otro, ah que unos tienen armas, a lo mejor si tienen armas pero jamás se comprobó, porque digo, es comprensible, yo puedo llevar una pistola, la saco y tú la ves, la vuelvo a guardar y ya me voy, si había un arma pero no tienes como comprobarlo si no me tomaste una foto o un video, entonces si humo muchas cosas de ese tipo", explica.

Así como se utilizaron las redes sociales para alentar disturbios fuera de las instalaciones del periódico Milenio y la televisora de Multimedios, también fue a través de ellas donde se difundieron muchas fake news que extrañamente después se convertían en verdaderas.

Daniela Mendoza señala que "había, por ejemplo, mensajes en Twitter (fuente: “disturbios en ciudad Solidaridad por el gasolinazo' a las 3 o 4 de la tarde, mandamos gente, pero no había nada; pero después de la manifestación si los hubo."

\section{Sobre la agresión a los medios de comunicación}

Sólo dos de los entrevistados quienes pertenecen al grupo Multimedios - Milenio, detallaron los ataques específicos hacia la prensa, estos no trascendieron por los canales tradicionales, y se dieron a conocer solo en redes sociales.

César Cubero (2018) explica que se sucedieron dos tipos de agresiones durante el evento; la primera hacia el edificio sede del Ejecutivo Estatal, pero la otra, de un modo que parecía planeado, se encaminaron casi inmediatamente hacia los integrantes de los medios de comunicación, especialmente de las televisoras Multimedios y Televisa.

“... ya estando ahí tú ya sabías de que ya estaba dirigido para los medios de comunicación en especial para Multimedios, para Televisa, para las televisoras, la violencia de los petardos, en los vitrales y toda esa parte de la violencia hacia el Estado o hacia la autoridad fue una, pero luego a la violencia directa contra los 
medios, eso sí estuvo muy marcado que eran dos tipos de cosas distintas, se acabó una y empezó la otra".

Cuando se desataron los hechos violentos en la Explanada de los Héroes varios de los reporteros que realizaban cobertura ese día fueron agredidos y Daniela Mendoza, como jefa de información tuvo que sacarlos de ahí. Tal como relató en la entrevista respecto a una de sus reporteras "no podía salir, la gente no la dejaba salir".

Al final paramédicos la resguardaron en una ambulancia cercana, y saqué del lugar a los demás, solo dejé a un fotógrafo y un reportero".

Mendoza también relata que "se comentaba mucho de la posibilidad de algún disturbio respecto de un atropello de un menor de edad". "En redes sociales se generaba mucho odio contra multimedios así que había gente rondando, hubo problemas fuera del canal... y estuvimos encerrados hasta medianoche".

\section{Referencias bibliográficas}

Albarrán, A. (1999). Investigación sobre la economía de los medios de comunicación; paradigmas y contribuciones. Comunicación y Sociedad, 12, 7-20.

Campos, L (2014). La ruptura del monopolio televisivo en México: el caso TV Azteca. Tesis Doctoral. Universidad Complutense de Madrid. España.

González, M (febrero de 2010) Los líderes de opinión o influentials en las redes sociales de Internet. Hacia el Three-Step Flow que defina los procesos de influencia personal en la red. En H. García (Presidencia) I Congreso Internacional AE-IC Málaga 2010 "Comunicación y desarrollo en la era digital", Congreso llevado a cabo en Málaga, España.

Mosco, V. (2006, abril 10). La Economía Política de la Comunicación: una actualización diez años después. CIC Cuadernos de Información y Comunicación, 11, 57-79. 
Lazarsfeld, P y Menzel, H (1975) Medios de Comunicación Colectiva e Influencia Personal, en Wilbur Schramm (comp.) La Ciencia de la Comunicación Humana, Editorial Roble, México.

Lozano, J (2007) Teória e Investigación de la Comunicación de Masas. Pearson Educación, México.

Reuters (2017) Reuters Institute News Report 2017. Recuperado de https://es.scribd.com/document/371166135/Digital-News-Report2017\#from embed

Hernández (28 de enero de 2017) AMLO y Salinas Pliego ¿Acuerdo con la Mafia del Poder? Huffingtonpost. Recuperado de: http://www.huffingtonpost.com.mx/2017/01/28/amlo-ysalinas-pliego-acuerdo-con-la-mafia-en-el-poder a 21702035/

Vidal, F (5 de junio de 2014). La Rueda de la Fortuna. Bitácora de Economía y medios de comunicación. Recuperado de https:/ ruedadelafortuna.com.mx/tag/guillermo-salinaspliego/

Vivas, M (23 de febrero del 2012) Arena Ciudad de México: un negocio redondo de Guillermo Salinas Pliego. Recuperado de: 


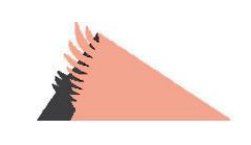

Conclusiones

\title{
Ciudadanía, medios de comunicación y redes sociales; una triada que genera luchas visibles, reconocimiento y credibilidad
}

\author{
Juan Antonio Garza Sánchez \\ Moncerrat Arango Morales
}

L

A SOCIEDAD cada vez se define como, altamente mediatizada, masivos de comunicación, sino también, debido al desarrollo de las redes sociales en Internet.

La naturaleza, de por sí ya constructiva de los medios masivos de comunicación, ve en las redes sociales el perfecto aliado para reforzar los diferentes contextos políticos y sociales. Esto a su vez genera la posibilidad que los ciudadanos puedan reinventar la construcción de una esfera pública contemporánea en donde su voz se revela ante la instantaneidad.

El modo en que funcionan las redes sociales, permiten que los ciudadanos reflexionen, sobre ejes públicos que veían distantes y exclusivos para las elites del poder. En la actualidad miles de ciudadanos democratizan más que nunca la opinión pública, al exponer sus discursos y posturas en un mundo virtual, pero bajo la construcción de la realidad que preparan los medios masivos tradicionales.

El alimento de la esfera pública se nutre hoy de ciudadanía, medios de comunicación y redes sociales; una triada que genera luchas visibles, reconocimiento y por supuesto credibilidad. 
Y fue así como el fenómeno llamado "El gasolinazo", generado en México los primeros días del 2017, a causa del mayor incremento en 20 años al precio de la gasolina; puso a prueba esta triangulación comunicativa que termino en protestas; que pasaron del reclamo pacifico, al saqueo, disturbios y toma de autopistas y gasolineras. Arrojando un resultado de miles de personas detenidas, cientos de comercios robados, hurto de combustible, cierre de carreteras y pérdida de vidas.

Fue así como las plataformas digitales pusieron a prueba la formación de opinión y de activismo social y político; muy a la mexicana, en donde la gestión de la visibilidad, la publicación; el diálogo y la deliberación, tomaron una dimensión que debe ser estudiada, a fin de prever la lectura que los ciudadanos hacen ante la construcción de los medios masivos tradicionales, y el poder e influencia de la opinión expresada en las redes sociales.

Este trabajo estudia y analiza las consecuencias que "el Gasolinazo" género en un nuevo entorno y soporte comunicativo; que crea y organiza mensajes en todas direcciones, permitiendo la generación de subredes que interactúan entre sí, de formas que aún deben ser analizadas.

$\mathrm{Y}$ es que es importante para los especialistas en la comunicación afrontar los retos de estas nuevas construcciones contemporáneas que hacen política, y en la que sus actores se apoyan en la capacidad de una tecnología para maximizar su influencia.

A lo largo del trabajo, se repasó al origen de los medios de comunicación masivo y los sitios en internet que influyeron en la decisión de los ciudadanos a protestar; se analizó el flujo de información generado en los sitios y la respuesta y búsqueda de los ciudadanos a estos datos.

Asimismo, se presentó la postura de los responsables de los medios de comunicación tradicional, que cubrieron el fenómeno en el área metropolitana de Monterrey, Nuevo León, México; cuyos ciudadanos, en perspectiva histórica, no responden a provocaciones, pero que, 
durante el desarrollo de las protestas, y siendo una de las entidades del país más digitalizadas, salieron a las calles para reclamar las acciones de gobierno.

Se registra además la versión de dos de los políticos de Nuevo León, que, aprovechando el contexto, enarbolaron la bandera del apoyo ciudadano, aumentando su credibilidad a partir de las redes sociales.

Estas ópticas permiten contraponer cada una de las versiones y reconocer que la instantaneidad de las plataformas digitales en el campo de la esfera pública permite llegar a las conclusiones que a continuación se describen.

En "Las redes sociales en la esfera pública como escaparate de Problemáticas sociales" destaca el como la comunicación política es la primera de las interacciones sociales, que sufren el impacto del protagonismo de la tecnología, cambiando su estructural y modelo elitista, por una democratización que amplía los canales de comunicación entre la política y los ciudadanos, transformando así la opinión pública.

Además, se determina que las redes sociales son aprovechadas por los políticos para acallar rumores o desmentir información; en lo referente al fenómeno "Gasolinazo" estas se convirtieron en un canal para desahogar el descontento social y convocar a la ciudadanía.

Destacar que el documento "Antecedentes e Historia de los Medios de Comunicación" concluye que el contexto "gasolinazo" se construyó gracias a los medios masivos; pues fueron ellos los que difundieron la postura gubernamental del aumento; sembrando una expectativa que exploto en una retroalimentación "on line" expresada a través de las redes sociales.

En la capitulo "El gasolinazo en los medios tradicionales" se determina que Los ciudadanos inundaron las redes de posturas y discursos, que posteriormente se materializaron en protestas, que pasaron de pacificas a violentas, debido a las subredes que se generaron durante el proceso. 
Se desatacan 12 clases distintas, de las cuales la mayoría se relacionan a organizaciones civiles, quedando en segundo término los ciudadanos que no pertenecían a ninguna de ellas, y quienes fueron los que al final rechazaron la violencia.

Por último, el documento "Hallazgos; El Papel De Las Redes Sociales" concluye que la oportunidad política también se generó a raíz de estas manifestaciones; hubo quienes ampliaron su plataforma de seguidores, guiando a los ciudadanos y apoyando las expresiones populares de rechazo y descontento; propiciando una comunicación negativa.

Los Periodistas y medios de comunicación tradicionales, involucrados en las protestas desarrolladas en el estado mexicano de Nuevo León, admiten que la instantaneidad de las redes sociales y las manifestaciones de los internautas los llevaron a difundir información falsa que generó decisiones equivocadas por parte de la ciudadanía.

Y durante el proceso de manifestación pública, se generó un ruido en la comunicación, que nombraron "Infiltrados", quienes fueron los encargados de sepultar las aspiraciones de los ciudadanos que solo querían hacer escuchar su voz.

El trabajo en su conjunto concluye que la triada, identificada entre medios masivos, redes sociales y ciudadanos; que generó el fenómeno "Gasolinazo", permitió predecir los futuros alcances del nuevo panorama en la esfera pública mexicana; identificando la creación de subgrupos que interfieren con este nuevo proceso comunicativo, y que al parecer generan un ruido en la comunicación cuya característica, la instantaneidad; no permite controlar las consecuencias sociales en momentos en donde el descontento y los sentimientos de desigualdad mueven a las masas. 

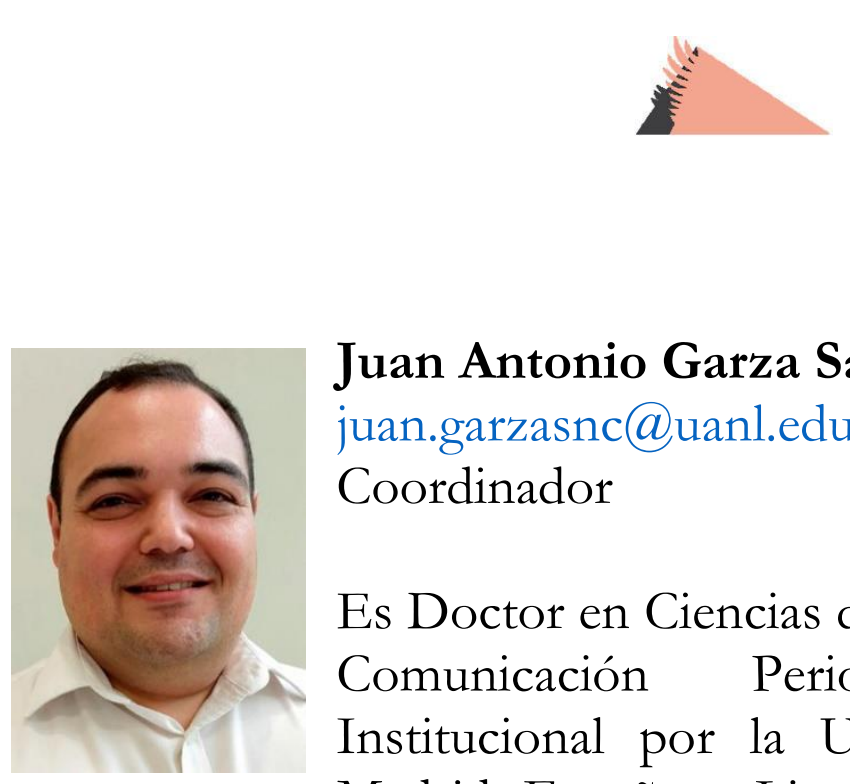

\section{Juan Antonio Garza Sánchez \\ juan.garzasnc@uanl.edu.mx \\ Coordinador}

Es Doctor en Ciencias de la Información y Máster en Comunicación Periodística Empresarial e Institucional por la Universidad Complutense de Madrid, España, y Licenciado en Comunicación por la Universidad Autónoma de Nuevo León.

Profesor e Investigador de la UANL desde hace más de 10 años y Miembro del Sistema Nacional de Investigadores del Conacyt, Nivel Candidato. Pertenece al CA "Comunicación, Ciudadanía y Grupos Vulnerables". Sus estudios se relacionan con el estudio del periodismo, los medios de comunicación y la cultura.

http:/ / orcid.org/0000-0002-8536-6321

http:/ / scholar.google.es/ citations?user $=8 \mathrm{~K} 4$ oSoAAAAAJ\&hl=es

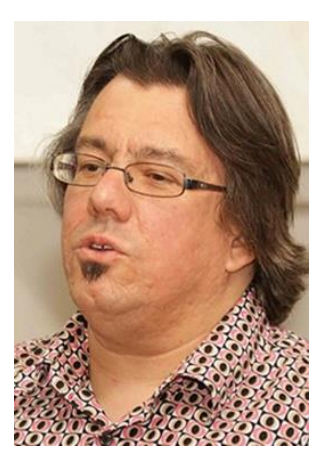

\section{Héctor Fouce Rodríguez}

hfoucero@ucm.es

Prologuista

Doctor en Periodismo por la Universidad Complutense de Madrid, Master en Propiedad Intelectual. Universidad Autónoma de Madrid (2010), Licenciado en Periodismo por la Universidad Complutense de Madrid (1996).

Líneas de investigación: Cultura popular, música popular, industria musical, propiedad intelectual, semiótica. 


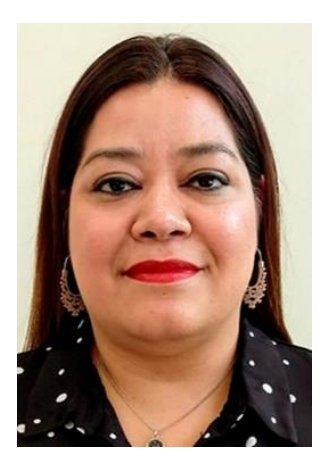

\section{Daniela Mendoza Luna}

danielamendozafcc@gmail.com

Autor

Estudiante de la Maestría en Ciencias de la Comunicación, Licenciada en Letras Españolas por la Universidad Autónoma de Nuevo León, y Catedrática de la Facultad de Ciencias de la Comunicación UANL desde hace 4 años.

Periodista con interés en el análisis del discurso público y las noticias falsas, la perspectiva de género y el periodismo de investigación. https:/ / orcid.org/0000-0001-6215-619

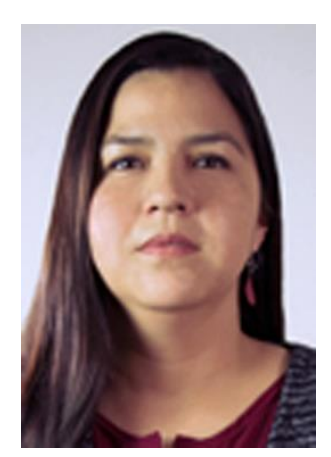

\section{Laura Lizeth Campos Guido}

camposguido@hotmail.com

Autor

Es Doctora en Ciencias de la Información por la Universidad Complutense de Madrid, España, recibiendo la calificación de Sobresaliente "Cum Laude" por su tesis; Máster en Comunicación Periodística Empresarial e Institucional por la misma Universidad y Licenciada en Comunicación por la Universidad Vasco de Quiroga, en Michoacán.

Profesora e Investigadora de la Universidad Autónoma de Nuevo León desde hace más de 10 años. Es Miembro del Sistema Nacional de Investigadores del Conacyt, Nivel Candidato. Pertenece al CA "Comunicación, Ciudadanía y Grupos Vulnerables". Sus estudios versan en el estudio del periodismo, los medios de comunicación y las estructuras de los mismos.

http:/ / orcid.org/0000-0002-8958-4836?lang=en https://scholar.google.es/citations? user $=$ sPR3gPwAAAAJ\&hl=es 


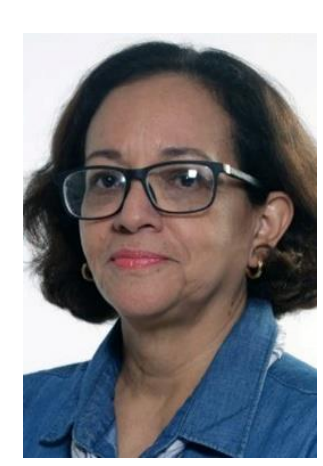

\section{Montserrat Arango Morales}

ayeryhoy5@yahoo.com

Autor

Doctora en Filosofía con orientación en Ciencia Política, Maestría en Arte con Especialidad en Educación, Licenciada en Ciencias de la Comunicación con Especialidad en Relaciones Públicas, Maestra de Tiempo Completo de la Facultad de Ciencias de la Comunicación de la Universidad Autónoma de Nuevo León.

Perfil PRODEP, trabajó como productor por 31 años en la Televisora pública del Estado de Nuevo León, Secretaria Ejecutiva del Consejo Consultivo Ciudadano del Sistema de Radio y Televisión de Nuevo León, sus líneas de investigación son: Formación ciudadana en Niños de ocho a doce años. https:// orcid.org/0000-0002-8399-8448

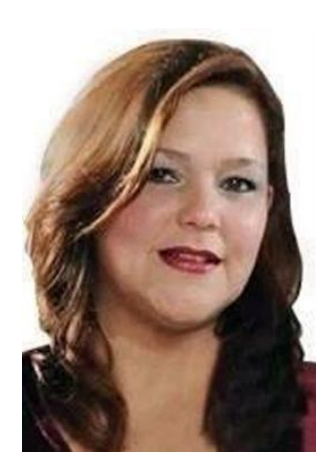

\section{Margarita González Treviño} maguiegzzt@gmail.com

Autor

Es Doctora en Educación por la Nova Southeastern University y Máster en Ciencias de la Comunicación por la Universidad Autónoma de Nuevo León. Profesora e Investigador desde hace más de 20 años de la UANL y Miembro del Sistema Nacional de Investigadores del Conacyt, Nivel Candidato. Pertenece al CA "Estudios de Comunicación, Ciudadanía y Grupos Vulnerables". Sus estudios se relacionan con la calidad educativa y el uso de la comunicación para la equidad e igualdad de género y los grupos vulnerable.

https:/ / orcid.org/0000-0003-4081-2284

https:// scholar.google.es/ citations?user=5SPXtSkAAAAJ\&hl=es 


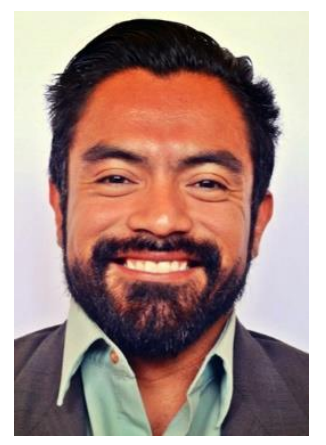

\section{Hiram Garrido Ledezma}

hiram.garridold@uanl.edu.mx

Autor

Máster en Relaciones Públicas y Gabinetes de Comunicación por la Universidad Autónoma de Barcelona, licenciado en Ciencias de la Comunicación con especialidad en Periodismo por la Universidad Autónoma de Nuevo León (UANL), Doctorando de Filosofía con orientación en Ciencias Políticas por la UANL, Profesor de licenciatura de la Facultad de Ciencias de la Comunicación, UANL.

Profesor titular de la materia de Relaciones Públicas en el Deporte de la Maestría en Comunicación Deportiva y Coordinador de Programas para la Sustentabilidad en la Secretaría de Sustentabilidad de la Universidad Autónoma de Nuevo León. Climate Reality Member por The Climate Reality Project.

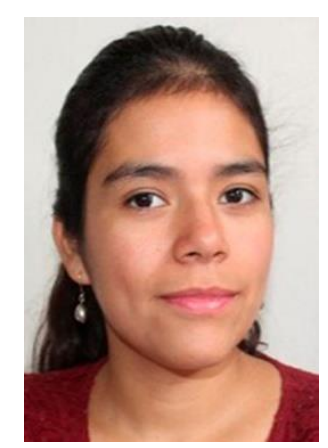

\section{Xitlalic Candia Cortés}

xcandia136@gmail.com

Colaborador

Licenciada en Ciencias de la Comunicación por la Universidad Autónoma de Nuevo León (UANL). Actualmente cursa el posgrado en Ciencias Políticas como becaria CONACYT, también en la UANL.

Ha participado como ponente en diversos congresos nacionales e internacionales.

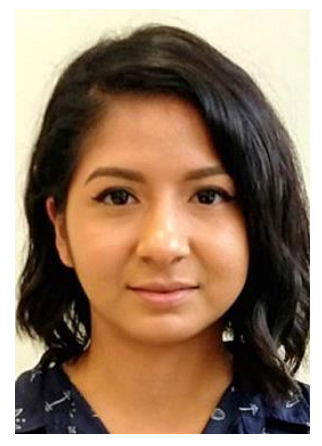

\section{Ana Victoria Félix Llanas}

victoria.felix@hotmail.com

Colaborador

Egresada de la Facultad de Ciencias de la Comunicación de la Universidad Autónoma de Nuevo León (UANL) con acentuación en Información, 
periodista en MILENIO Monterrey y colaboradora del Grupo Multimedios, realiza enlaces para radio y televisión en temas medioambientales, sociales y de política.

Participó en el programa de verano de la Investigación Científica y Tecnológica de (PROVERICYT 2018).

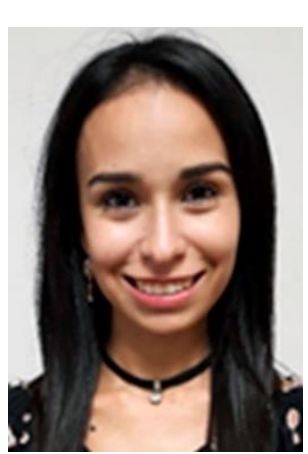

\section{Paloma Flores Estudon}

palomaflorestudon@gmail.com

Colaborador

Es Licenciada en Ciencias de la Comunicación, por la Facultad de Ciencias de la Comunicación de la Universidad Autónoma de Nuevo León, Participante en el PROVERICYT UANL, amante de la Investigación y temas de sociedad, sus estudios están orillados hacia la redacción y periodismo en donde buscara desarrollarse y tomar la experiencia necesaria para llevarlos a cabo.

Consciente de que aún queda camino por recorrer y con la visión de seguir estudiando para lograr las metas propuestas.

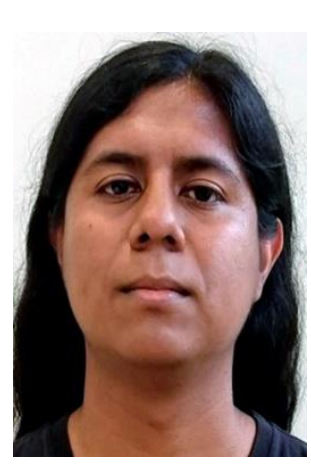

\section{Juan Pablo Galván García}

juanpabloggarcia@outlook.es

Colaborador

Estudiante de la Facultad de Ciencias de la Comunicación por la Universidad Autónoma de Nuevo León.

Intereses: Lectura, Arte y Tecnología 


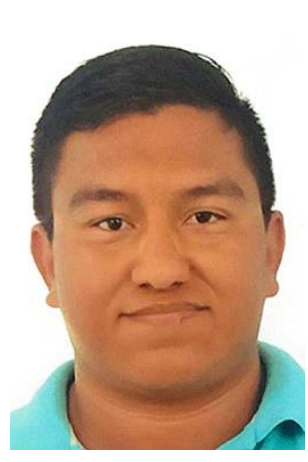

\section{Brandon Eliud Ipiña Aldaba}

\section{eliud.aldaba10@gmail.com}

Colaborador

Egresado de la Facultad de Ciencias de la Comunicación de la Universidad Autónoma de Nuevo León (UANL), Colaborador en canal 53 de la UANL, Operador de transmisión en TV Azteca Noreste.

Intereses: Lectura, periodismo y producción de Televisión.

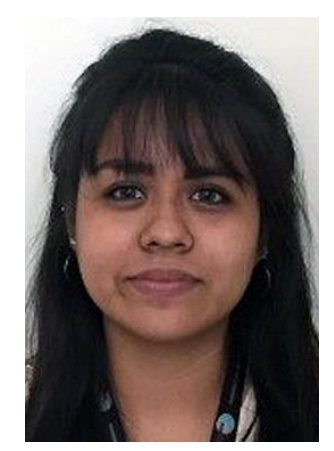

\section{Kelly Yohana Molina Bustos}

kelly_molina@hotmail.com

Colaborador

Estudiante de la Facultad de Ciencias de la Comunicación por la Universidad Autónoma de Nuevo León. Amante del aprendizaje diario, adoradora del mundo y sus diferentes culturas, entusiasta por la verdad, curiosa ante todo lo que me rodea, todo lo que percibo, lo físico, lo psicológico, lo astrológico, lo literario y lo abstracto del alma.

Intereses: Idiomas, Lectura, Danza y Marketing.

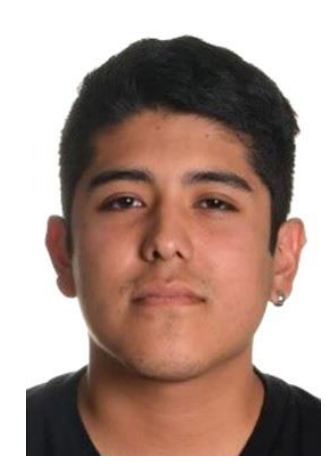

\section{Carlos Emiliano Ortega Gutiérrez}

ortega-100@live.com

Colaborador

Estudiante de la Facultad de Ciencias de la Comunicación por la Universidad Autónoma de Nuevo León.

Intereses: Periodismo, literatura, fotografía, multiculturalidad, política y deportes 